\title{
Late Triassic - Jurassic development of the Danish Basin and the Fennoscandian Border Zone, southern Scandinavia
}

\author{
Lars H. Nielsen
}

The continental to marine Upper Triassic - Jurassic succession of the Danish Basin and the Fennoscandian Border Zone is interpreted within a sequence stratigraphic framework, and the evolution of the depositional basin is discussed. The intracratonic Permian-Cenozoic Danish Basin was formed by Late Carboniferous - Early Permian crustal extension followed by subsidence governed primarily by thermal cooling and local faulting. The basin is separated from the stable Precambrian Baltic Shield by the Fennoscandian Border Zone, and is bounded by basement blocks of the Ringkøbing-Fyn High towards the south. In Late Triassic - Jurassic times, the basin was part of the epeiric shallow sea that covered most of northern Europe. The Upper Triassic - Jurassic basin-fill is subdivided into two tectono-stratigraphic units by a basinwide intra-Aalenian unconformity. The Norian - Lower Aalenian succession was formed under relative tectonic tranquillity and shows an overall layer-cake geometry, except for areas with local faults and salt movements. Deposition was initiated by a Norian transgression that led to shallow marine deposition and was accompanied by a gradual climatic change to more humid conditions. Extensive sheets of shoreface sand and associated paralic sediments were deposited during short-lived forced regressions in Rhaetian time. A stepwise deepening and development of fully marine conditions followed in the Hettangian - Early Sinemurian. Thick uniform basinwide mud blankets were deposited on an open storm-influenced shelf, while sand was trapped at the basin margins. This depositional pattern continued until Late Toarcian - Early Aalenian times when the basin became restricted due to renewed uplift of the Ringkøbing-Fyn High. In Middle Aalenian - Bathonian times, the former basin area was subjected to deep erosion, and deposition became restricted to the fault-bounded Sorgenfrei-Tornquist Zone. Eventually the fault margins were overstepped, and paralic-marine deposition gradually resumed in most of the basin in Late Jurassic time. Thus, the facies architecture of the Norian - Lower Aalenian succession reflects eustatic or large-scale regional sea-level changes, whereas the Middle Aalenian - Volgian succession reflects a strong tectonic control that gradually gave way to more widespread and sea-level controlled sedimentation. The uplift of the Ringkøbing-Fyn High and most of the Danish Basin occurred concurrently with the uplift of the North Sea and a wide irregular uplifted area was formed, which differs significantly from the postulated domal pattern.

Keywords: Danish Basin, Fennoscandian Border Zone, Upper Triassic - Jurassic, sedimentology, sequence stratigraphy, basin development, intra-Aalenian unconformity, sea-level control

Geological Survey of Denmark and Greenland, Geocenter Copenhagen, Øster Voldgade 10, DK-1350 Copenhagen K, Denmark. E-mail: lbn@geus.dk 
The deeply buried Upper Triassic - Jurassic succession of the Danish Basin and the Fennoscandian Border Zone has been a target for exploration activities since 1935 and c. 60 deep wells have been drilled for hydrocarbons, geothermal energy or gas storage in the Danish area (Sorgenfrei \& Buch 1964; Nielsen \& Japsen 1991). Outcrops only occur along the basin margin in Skåne and Bornholm (Gravesen et al. 1982, Norling et al. 1993).

The aims of the paper are to interpret the Upper Triassic - Jurassic basin-fill within a sequence stratigraphic framework, to describe the spatial distribution of facies and depositional sequences, and to provide a scheme for comparison of the deeply buried basinal successions with the basin margin successions partially exposed in Skåne and on Bornholm. The results are presented in chronostratigraphic schemes. A relative sealevel curve is constructed and compared to eustatic curves and curves from other parts of the Jurassic epeiric sea, and subsidence curves for five selected positions in the basin are presented. The formation and timing of the significant intra-Aalenian unconformity is discussed and compared to the coeval North Sea unconformity. The paper concludes with a description of the Late Triassic - Jurassic evolution of the basin.

The study utilises well logs from more than 40 wells and a large number of geographically and stratigraphically widely distributed cores from the Gassum, Fjerritslev, Haldager Sand and Flyvbjerg Formations. Facies associations are defined from sedimentological core logs, because associations rather than individual facies can be recognised on well logs. Non-cored sections are interpreted by means of well logs and information from sidewall cores, cuttings samples, biostratigraphic and palaeoecological data.

\section{Tectonic setting}

The Danish Basin is roughly synonymous with the Danish Embayment (Sorgenfrei \& Buch 1964; Larsen 1966; Michelsen 1975), the Danish part of the Norwegian-Danish Basin (Bertelsen 1978; Michelsen 1978) and the Danish Subbasin (Michelsen 1989a, b). The basin is an intracratonic, Permian-Cenozoic structure that trends WNW-ESE. It is bounded by basement blocks of the Ringkøbing-Fyn High to the south and by the Fennoscandian Border Zone to the north-east (Figs 1, 2). The border zone demarcates the transition to the stable Precambrian Baltic Shield and includes the Sorgenfrei-Tornquist Zone and the Skagerrak-
Kattegat Platform (Sorgenfrei \& Buch 1964; Bergström 1984; EUGENO-S Working Group 1988). The SorgenfreiTornquist Zone forms the northern segment of the Tornquist Zone which is a long-lived fundamental tectonic feature. It converges with the Teisseyre-Tornquist Zone via the Rønne Graben offshore Bornholm (Fig. 1), where the Danish Basin passes into the Polish Trough. The Sorgenfrei-Tornquist Zone is strongly block-faulted, 30-50 km wide, with tilted Palaeozoic fault blocks unconformably overlain by thick Mesozoic deposits that show pronounced late Cretaceous - early Cenozoic tectonic inversion. The Skagerrak-Kattegat Platform is a stable area to the north-east where the Mesozoic deposits onlap Lower Permian, Lower Palaeozoic and Precambrian crystalline rocks in tilted fault blocks and gradually thin out towards the Baltic Shield (Fig. 2).

The deepest regional surface mappable by reflection seismic data in the Danish Basin and Fennoscandian Border Zone is the top pre-Zechstein surface, which is a pronounced unconformity truncating tilted fault blocks in most of the area (Vejbæk 1989, 1997; Britze \& Japsen 1991; Michelsen \& Nielsen 1991, 1993; Vejbæk \& Britze 1994). The unconformity is penetrated by wells which show the occurrence of Precambrian crystalline rocks on the Ringkøbing-Fyn High (Glamsbjerg-1, Grindsted-1, Ibenholt-1 and Jelling-1) and the SkagerrakKattegat Platform (Frederikshavn-1) and Lower Palaeozoic sedimentary rocks in the Danish Basin and Fennoscandian Border Zone (Nøvling-1, Rønde-1, Slagelse-1 and Terne-1; Sorgenfrei \& Buch 1964; Poulsen 1969, 1974; Christensen 1971, 1973; Larsen 1971, 1972; Michelsen \& Nielsen 1991, 1993; Nielsen \& Japsen 1991). The wells cut the unconformity on footwall blocks or on hangingwall block crests, where deep erosion has occurred, thus making accurate dating of the rifting impossible. In contrast, the Hans-1 and Sæby-1 wells are located in the deep hangingwalls of tilted fault blocks close to the footwall fault (Michelsen \& Nielsen 1991, 1993). In Sæby-1, on the Skagerrak-Kattegat Platform, the unconformity separates Triassic sediments from syn-rift Rotliegendes volcaniclastic rocks. In the Sorgenfrei-Tornquist Zone, Hans-1 penetrates a prerift succession of clastic sediments and extrusive volcanic rocks, of presumed Late Carboniferous age (Fig. 3). The succession is unconformably overlain by a thick Rotliegendes syn-rift prism of alluvial conglomerates and sandstones and lacustrine mudstones. The syn-rift succession is overlain by marginal to non-marine Zechstein deposits. In the nearby Terne- 1 well, Upper Carboniferous intrusive volcanic rocks occur, and the volcanic rocks in Hans-1 and Terne-1 seem to be roughly 


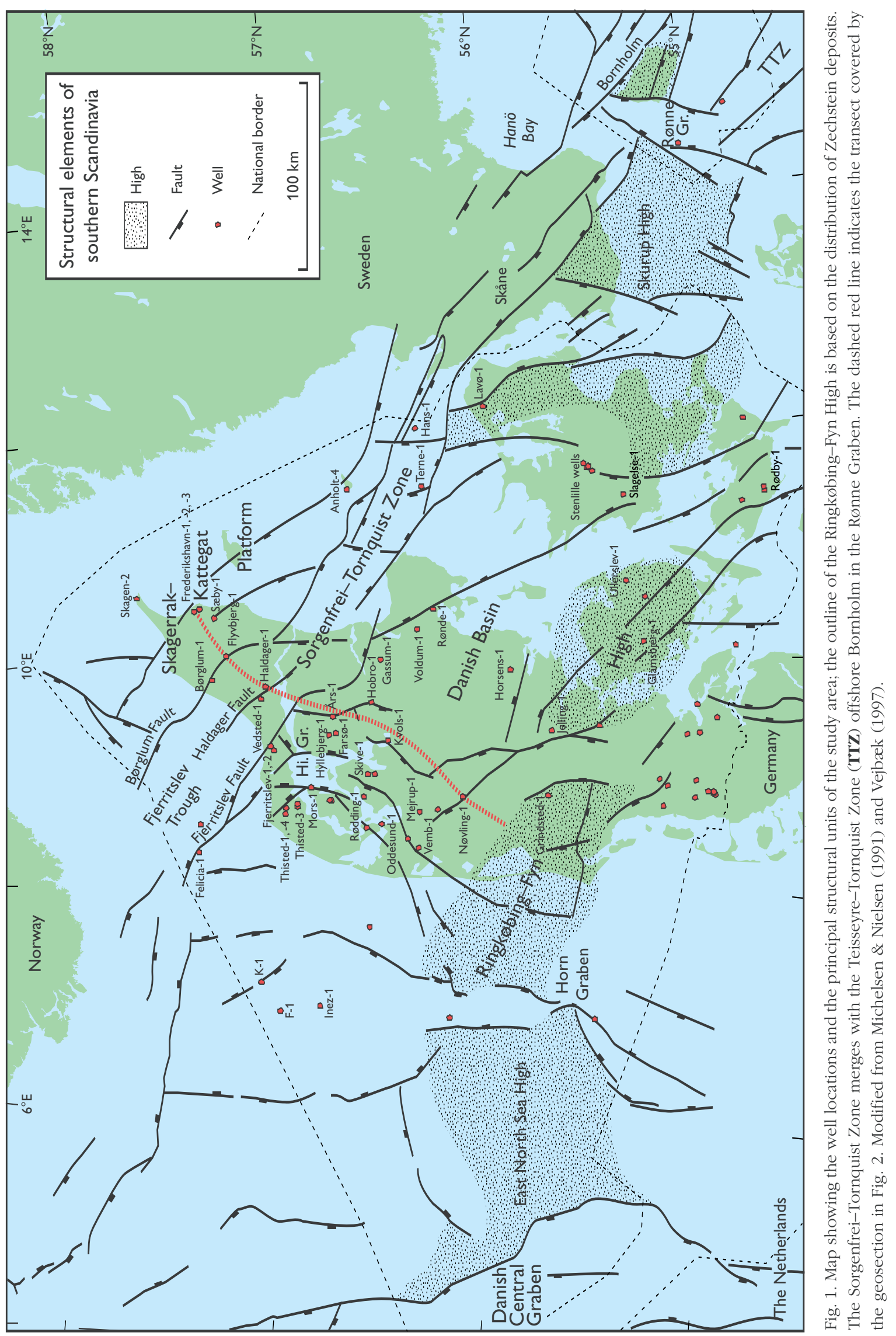



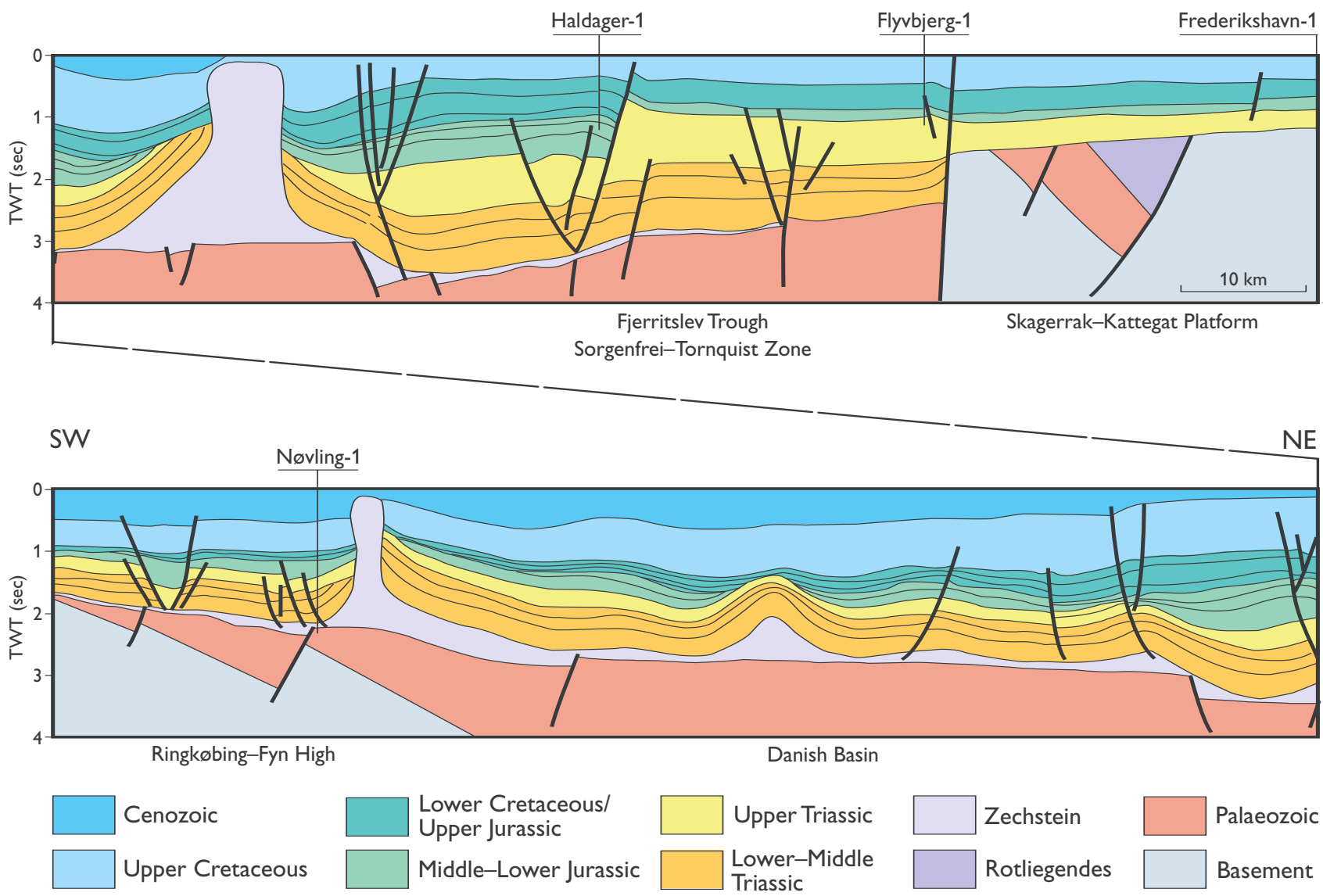

Fig. 2. A regional SW-NE geosection through the Danish Basin and the Fennoscandian Border Zone. For location, see Fig. 1. Modified from Vejbæk (1990, 1997). TWT, two-way travel time.

contemporaneous with the earliest volcanic rocks in the Oslo Graben and dolerite dykes in southern Sweden (Bergström et al. 1982; Ro et al. 1990). The principal phase of rifting of the Danish Basin and the Fennoscandian Border Zone thus occurred in the Late Carboniferous - Early Permian at the same time as, or slightly later than, rifting of the Oslo Graben (Ro et al. 1990; Michelsen \& Nielsen 1991, 1993).

The tilted fault block crests are deeply truncated by the mid-Permian unconformity showing that regional post-rift thermal subsidence was somewhat delayed (Vejbæk 1997). The unconformity defines the base of the post-rift succession and is overlain by a relatively complete succession of Upper Permian, Mesozoic and Cenozoic deposits that is $c .5-6.5 \mathrm{~km}$ thick along the basin axis and more than $9 \mathrm{~km}$ locally in the Sorgenfrei-Tornquist Zone and the Himmerland Graben (Fig. 2). Isochore maps of the Triassic and Jurassic Lower Cretaceous successions show a relatively uniform regional thickness over most of the basin except for areas influenced by local halokinetic movements, indicating relatively uniform thermal subsidence (Vejbæk 1989, 1997; Britze \& Japsen 1991; Japsen \& Langtofte 1991). Although the thick Upper Permian - Triassic succession indicates rapid subsidence that exceeds normal thermal contraction, a prolonged or new rifting phase is precluded by the general lack of pronounced extensional faulting in the Mesozoic succession (Vejbæk 1989, 1997). The evaporitic and continental facies show that the basin was never under-filled, and phase transformations in the deep crust have been proposed to explain the rapid early post-rift subsidence (Vejbæk 1989). The great thicknesses of the Mesozoic in the Himmerland Graben and the Fjerritslev Trough were facilitated by transtensional strike-slip movements in the SorgenfreiTornquist Zone and large-scale salt movements (Pegrum 1984; Vejbæk 1989; Christensen \& Korstgård 1994; Mogensen 1996).

A general shallowing of the basin towards the Ringkøbing-Fyn High is indicated by thinning of the 

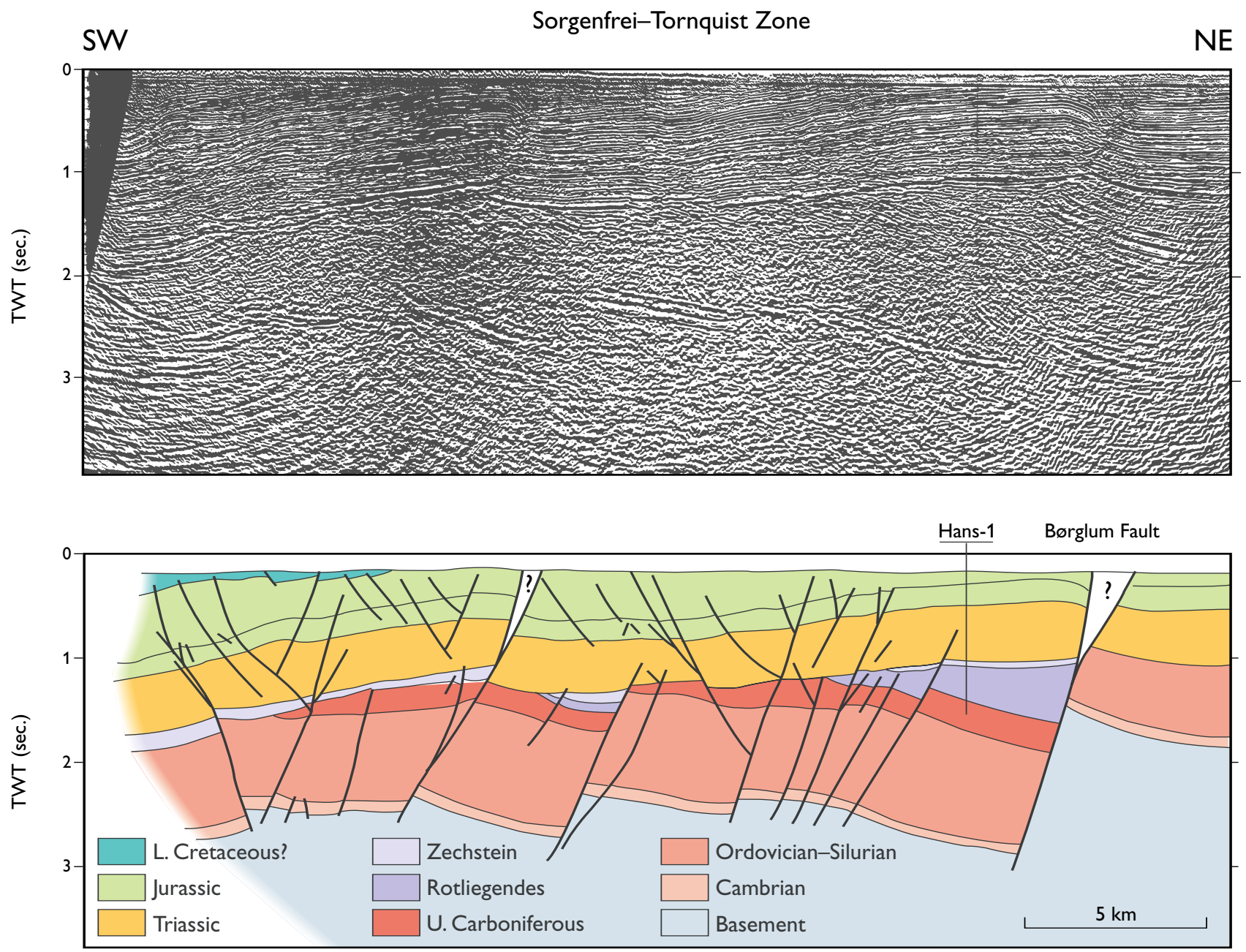

Fig. 3. A SW-NE geosection through the Sorgenfrei-Tornquist Zone, intersecting the Hans-1 well (see Fig. 1). Note the tilted Palaeozoic fault blocks, the Rotliegendes syn-rift prisms and the regional mid-Permian unconformity overlain by the relatively undisturbed Upper Permian - Mesozoic basin-fill. Modified from Michelsen \& Nielsen (1991, 1993). TWT, two-way travel time.

Zechstein - Lower Jurassic and Upper Jurassic - Lower Cretaceous successions although erosion at the base of the Middle Jurassic and the Cretaceous have obscured the original distribution of the Triassic - Lower Jurassic on the high. The high was probably formed at the same time as the Danish Basin as an area of less stretching (Vejbæk 1997). Marginal facies were developed along the high in Late Permian time and it probably formed a barrier between the Southern and Northern Zechstein basins (Ziegler 1982; Stemmerik et al. 1987). In Late Triassic - Early Jurassic times, the high became flooded during periods of high sea level (Michelsen 1975, 1978; Bertelsen 1978; L.H. Nielsen, L. Hamberg and E.B. Koppelhus in: Nielsen 1995). In Middle Jurassic time, it was uplifted causing a major change in the basin configuration (Michelsen 1978; Koch 1983; Nielsen 1993 , 1995).

\section{Upper Triassic - Jurassic stratigraphy}

The Upper Triassic - Jurassic succession is more than $1 \mathrm{~km}$ thick and includes the Skagerrak, Vinding, Gassum, Fjerritslev, Haldager Sand, Flyvbjerg, Børglum and Frederikshavn Formations (Fig. 4). The stratigraphic scheme currently applied is based on Sorgenfrei \& Buch (1964), Larsen (1966), Michelsen (1975, 1978, 1989a), Bertelsen $(1978,1980)$ and Michelsen et al. (2003, this volume). Claystones, marls and oolitic carbonates of the Norian Vinding Formation were deposited in a shallow, restricted marine environment in central parts of the basin and form a succession, 40-90 m thick, and locally up to 200 m (Bertelsen 1978, 1980; Nielsen \& Japsen 1991). Concurrently, alluvial arkosic sandstones and lacustrine claystones of the Skagerrak Formation were deposited in the northern and north-eastern, marginal parts of the 


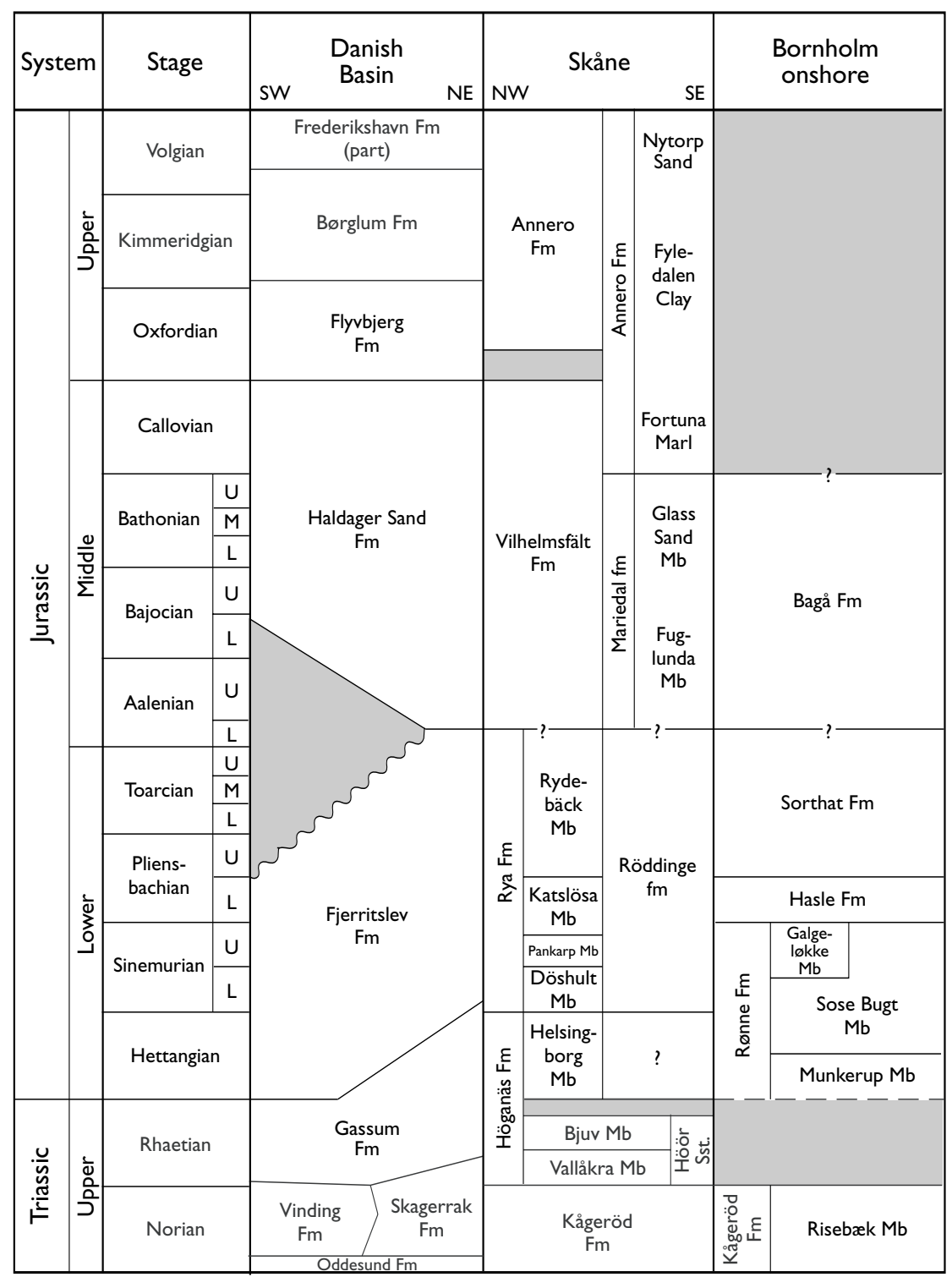

Fig. 4. Lithostratigraphic scheme for the Upper Triassic - Jurassic of the Danish Basin and the Fennoscandian Border Zone based on Bertelsen (1978, 1980), Michelsen (1978, 1989a), Gravesen et al. (1982), Sivhed (1984), Norling et al. (1993), Koppelhus \& Nielsen (1994), L.H. Nielsen, L. Hamberg and E.B. Koppelhus (in: Nielsen 1995), Ahlberg et al. (2003, this volume) and Michelsen et al. (2003, this volume).

basin. The uppermost Norian - Lower Sinemurian Gassum Formation overlies the Skagerrak Formation along the basin margin, and interfingers with the upper part of the Vinding Formation in the deep part of the basin (Bertelsen 1978; L.H. Nielsen, L. Hamberg and E.B. Koppelhus in: Nielsen 1995). The thickness varies from 50-150 $\mathrm{m}$ in the central part of the basin to more than $300 \mathrm{~m}$ locally in the Sorgenfrei-Tornquist Zone, and the formation consists of interbedded fine- to mediumgrained, occasionally coarse-grained and pebbly sandstones, heteroliths, mudstones and few thin coaly beds (Bertelsen 1978; Michelsen \& Nielsen 1991). Bivalves, foraminifers and rare ammonites occur in addition to common spores, pollen and dinoflagellate cysts. An overall fluvio-deltaic, deltaic to tidally-influenced shal- low marine environment has been proposed (Larsen 1966; Bertelsen 1978; Nielsen et al. 1989). The presence of several regressive shoreface sandstones of wide lateral extent shows, however, that the formation was formed under the influence of repeated sea-level fluctuations and not by simple deltaic progradation (Hamberg et al. 1992; Hamberg 1994; L.H. Nielsen, L. Hamberg and E.B. Koppelhus in: Nielsen 1995; Hamberg \& Nielsen 2000).

The overlying Lower Jurassic Fjerritslev Formation is dominated by marine claystones and mudstones containing ammonites, bivalves, foraminifers, ostracods and dinoflagellate cysts (Nørvang 1957; Larsen 1966; Michelsen 1975; Pedersen 1986; Dybkjær 1988, 1991; Poulsen 1996). The formation shows very variable thickness due 
to erosional truncation in the south-western and central parts of the basin and above salt structures, and a maximum thickness of more than $1000 \mathrm{~m}$ is reached in the fault-bounded Fjerritslev Trough (Fig. 2). Lower Jurassic mudstones and sandy mudstones are also present south of the Ringkøbing-Fyn High (Bertelsen \& Michelsen 1970; Michelsen 1973, 1975). The formation covers the Early Jurassic time interval, and also includes mudstones of latest Rhaetian and Early Aalenian age (Dybkjær 1991; Michelsen \& Nielsen 1991; Poulsen 1996). The transition from the Gassum Formation to the Fjerritslev Formation occurred in several steps ranging from latest Rhaetian in the central parts of the basin to Early Sinemurian at the north-eastern margin reflecting the overall Early Jurassic eustatic sea-level rise (Bertelsen 1978; Michelsen 1978, 1989b; Hallam 1988; Dybkjær 1991; Michelsen \& Nielsen 1991; Nielsen 1995).

The Haldager Sand Formation erosionally overlies the Fjerritslev Formation and consists of fine- to very coarsegrained, occasionally pebbly sandstones, siltstones, mudstones and coaly beds (Michelsen 1978, 1989a; Koch 1983). Koch (1983) proposed a general braided fluvial to deltaic depositional environment. The formation is absent on and along the Ringkøbing-Fyn High and is thin and patchy in large parts of the basin except for in rim-synclines close to salt structures (e.g. Mors-1, Thisted-3; Fig. 1). In the south-western part of the basin, it consists of fine- to coarse-grained fluvial sandstone units, 1-10 m thick, and thickens to more than
$150 \mathrm{~m}$ towards the north-east in the Sorgenfrei-Tornquist Zone, where the formation includes paralic and shallow marine sandstones and mudstones. Dating of the formation is generally poor giving a broad Middle Jurassic age (Michelsen 1978, 1989a; Michelsen \& Nielsen 1991; Poulsen 1992a, 1996). It is overlain by transgressive paralic-marine mudstones and sandstones of the Oxfordian Flyvbjerg Formation, which shows roughly the same distribution as the Haldager Sand Formation. Expansion and deepening of the basin is reflected by the change to the overlying Kimmeridgian-Ryazanian marine mudstones of the Børglum Formation and Volgian-Ryazanian marine to paralic siltstones, sandstones and mudstones of the Frederikshavn Formation that overstep the limits of the Flyvbjerg Formation (Michelsen 1978, 1989a; Michelsen \& Nielsen 1991; Poulsen 1996).

\section{Sedimentology of the Gassum, Fjerrits- lev and Haldager Sand Formations}

The Upper Triassic - Middle Jurassic siliciclastic deposits are composed of a number of relatively uniform and recurrent continental, paralic, nearshore and offshore facies that are grouped into six associations (L.H. Nielsen, L. Hamberg and E.B. Koppelhus in: Nielsen 1995; Hamberg \& Nielsen 2000). The typical well-log pattern for each association is described by comparing cores and well logs (Table 1).

Table 1. Typical well-log patterns of the facies associations

\begin{tabular}{|c|c|}
\hline $\begin{array}{l}\text { Fluvial facies } \\
\text { association }\end{array}$ & $\begin{array}{l}\text { The logs show sharp-based, blocky motifs with fairly consistently low gamma-ray readings, increasing in the upper part. The SP-log } \\
\text { pattern is very blocky in old wells. The gamma-ray readings are generally lower than those of the shoreface sandstones, although } \\
\text { atypically high values may be recorded in zones with abundant claystone clasts and/or diagenetic clay minerals. }\end{array}$ \\
\hline $\begin{array}{l}\text { Lacustrine facies } \\
\text { association }\end{array}$ & $\begin{array}{l}\text { SP-logs from the uppermost part of the Skagerrak Formation and the Gassum and Haldager Sand Formations show uniform } \\
\text { rightwards deflections. The change from variegated (Skagerrak or lower Gassum Formation) to greyish claystones (Gassum } \\
\text { Formation) on the Skagerrak-Kattegat Platform is marked by a significant rightwards deflection. }\end{array}$ \\
\hline $\begin{array}{l}\text { Estuarine facies } \\
\text { association }\end{array}$ & $\begin{array}{l}\text { The logs show sharp-based motifs, the basal part yielding low gamma-ray values followed by an overall increase in values upwards } \\
\text { reflecting the general fining-upwards of the association. Bell- or funnel-shaped motifs occur internally. Discrimination between the } \\
\text { lower sandy part of estuarine and fluvial deposits by log motifs alone may be difficult, but the heterolithic component of the estuarine } \\
\text { deposits generally causes more variable log patterns. }\end{array}$ \\
\hline $\begin{array}{l}\text { Lagoonal facies } \\
\text { association }\end{array}$ & $\begin{array}{l}\text { The log pattern is very variable. Some facies show an increase upwards in gamma-ray values in the basal part, reflecting increasing } \\
\text { mudstone content, followed by a decrease reflecting the incoming of sandstones. Others show several decreasing-upwards trends } \\
\text { reflecting coarsening- and cleaning-upwards heteroliths. A distinct decrease in gamma-ray values at the top marks a marine } \\
\text { transgressive erosion surface overlain by sandstones. Wave-reworked sandstones or channel sandstone units within the background } \\
\text { heterolith facies are indicated by distinct gamma-ray lows. A serrated log pattern indicates a dominance of stacked, fining-upwards } \\
\text { channel units (see Figs 7A, 9B). }\end{array}$ \\
\hline $\begin{array}{l}\text { Shoreface and } \\
\text { foreshore facies } \\
\text { association }\end{array}$ & $\begin{array}{l}\text { The typical gamma-ray and SP-log motifs are sharp-based and smooth, blocky to funnel-shaped, reflecting several almost amalgamated, } \\
\text { coarsening-upwards sandstone units or two to three sandstone units separated by heteroliths. The general coarsening-upwards } \\
\text { trend shown by cores is reflected by a weak decreasing-upwards gamma-ray trend or leftwards deflection of the SP-log. This trend } \\
\text { and commonly slightly higher gamma-ray values serves to discriminate shoreface from fluvial sandstones. }\end{array}$ \\
\hline $\begin{array}{l}\text { Marine offshore } \\
\text { facies association }\end{array}$ & $\begin{array}{l}\text { The well-log motifs of this facies association show high to intermediate gamma-ray readings, corresponding SP-values and low } \\
\text { sonic velocities forming both relatively uniform units and units showing decreasing- or increasing-upwards signals (see Figs } 8,10,13) \text {. }\end{array}$ \\
\hline
\end{tabular}




\section{Børglum-1}
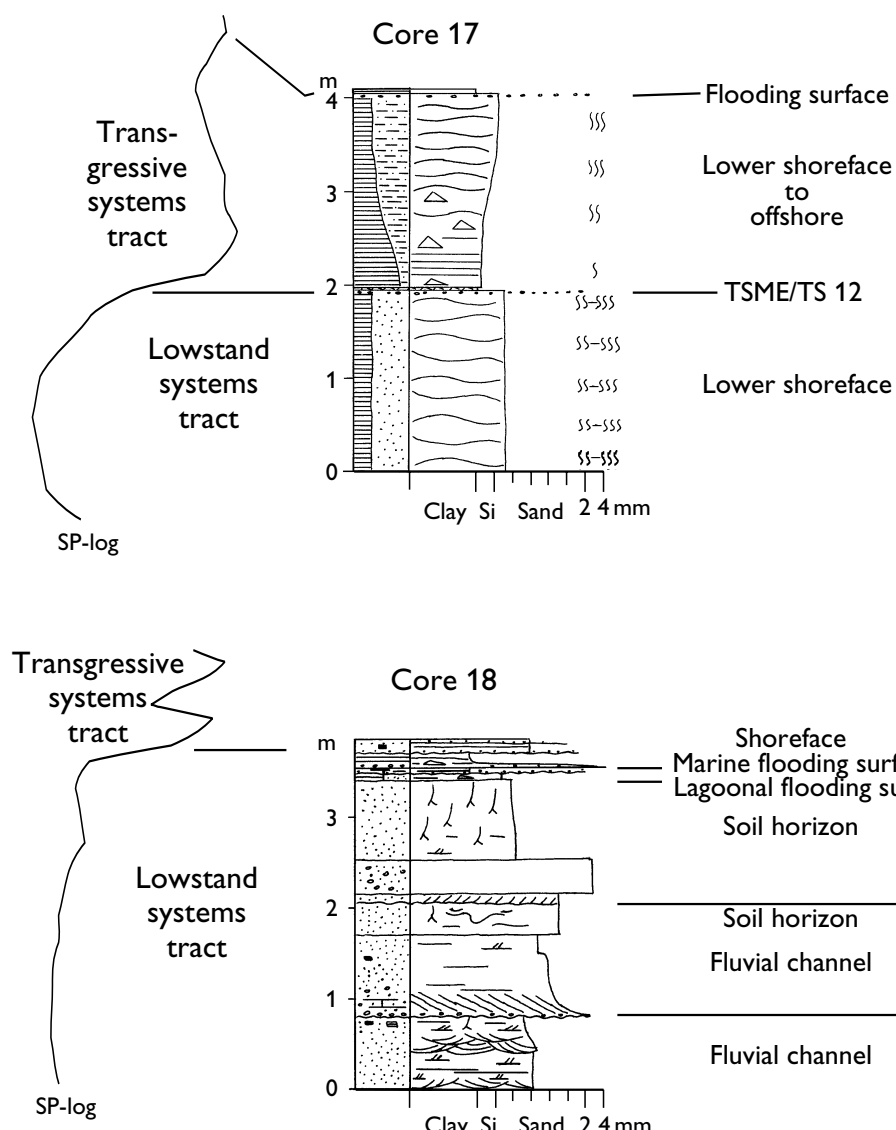

Core 18
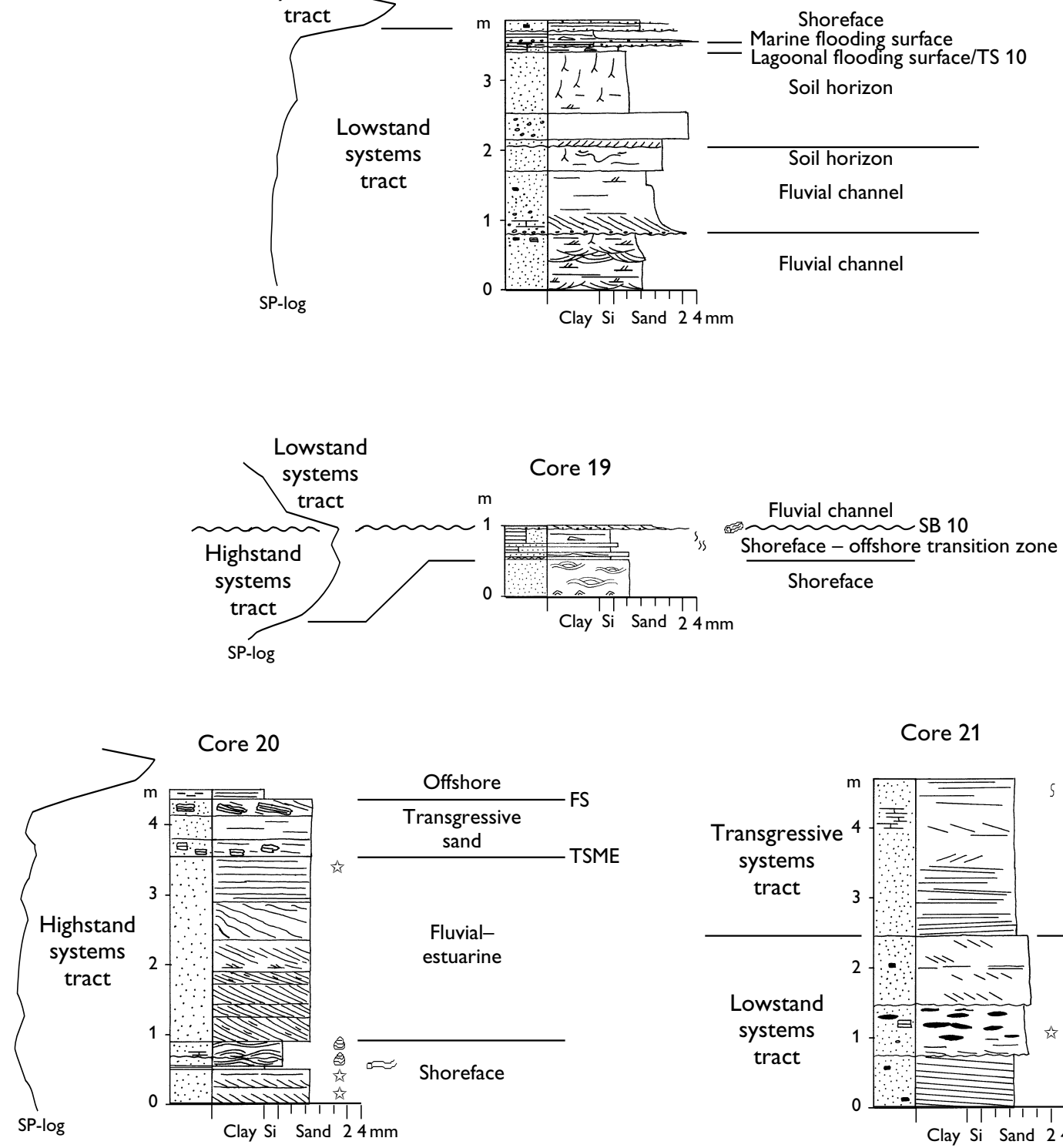

Core 21 


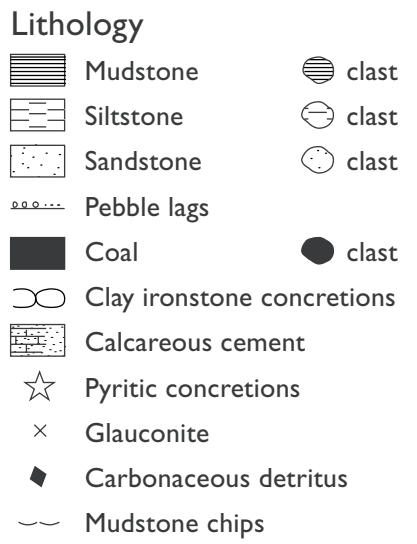

Fossils

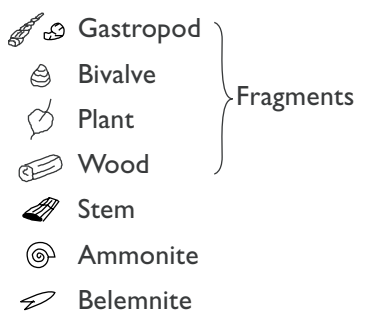

Sedimentary structures

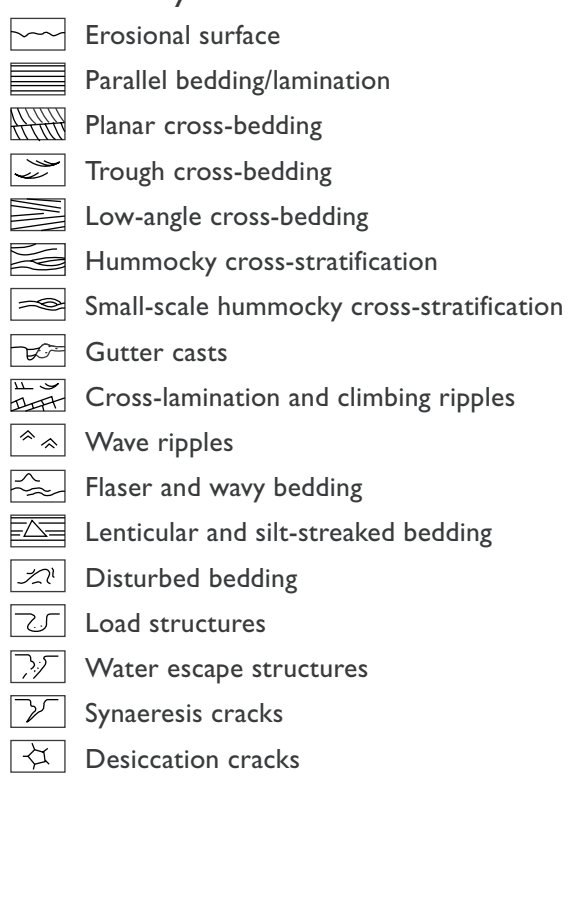

Biogenic structures

S-SSS Degree of bioturbation

Cryptobioturbation by amphipods

人. Chondrites isp.

造 Diplocraterion isp.

- 00 Helminthopsis isp.

(ब) Rhizocorallium isp.

१ Skolithos isp.

을 Teichichnus isp.

of Thalassinoides isp.

$\mathbb{0}$ Zoophycos isp.

$\approx$ Horizontal burrows

\}. Large (crustacean?)

$\approx$ Escape trace

$\lambda \lambda$ Rootlets

Facing page:

Fig. 5. Core logs of the Gassum (cores 18-21) and Fjerritslev Formations (core 17) in the Børglum-1 well (for location of the cores in the well, see Fig. 20). Core 21 shows a fluvial channel unit belonging to the lowstand systems tract (LST) of the Fj 1 sequence. It is capped by transgressive surface TS 9 overlain by a weakly bioturbated beach sandstone of the transgressive systems tract (TST). No well logs were obtained for this interval. Cores 20 and 19 show the highly variable deposits of the highstand systems tract (HST) of sequence Fj 1. Uppermost in core 19 is a coarse-grained, cross-bedded erosionally-based fluvial sandstone, the base of which marks SB 10 and the base of the Fj 2 sequence. Core 18 shows fluvial channel units with roots and soil horizons of the LST capped by TS 10 (sequence $\mathrm{Fj}$ 2); TS 10 is overlain by thinly preserved lagoonal deposits below a marine shoreface sandstone. Core 17 shows lower shoreface sandy heteroliths (LST; sequence Fj 4) overlain by transgressive, deeper water deposits (TST). The flooding surface TS 12 is defined by a lamina of very coarse-grained sand draped by $2-5 \mathrm{~cm}$ of cemented mudstone. Core depth is corrected to log depth by subtracting $3 \mathrm{ft}$. The accompanying legend (above) is applicable to all the core logs (Figs 5-14). FS, flooding surface; SB, sequence boundary; TS, transgressive surface; TSME, transgressive surface of marine erosion.

\section{Fluvial facies association}

In the Gassum Formation, the facies association is most common in the Fjerritslev Trough, but it also occurs in the basin centre. It was cored in the Børglum-1, Flyvbjerg-1, Frederikshavn-2, Horsens-1, Thisted-3, Vedsted-1 and Års-1 wells (Figs 5, 6, 7, 8, 9A, 12, 15). The association dominates the Haldager Sand Formation and was cored in the Fars $\varnothing-1$, Frederikshavn-1 and -3, Haldager-1, Skagen-2, Vedsted-1 and Års-1 wells (Fig. 10B).

The association typically consists of fining-upwards units, 2-14 m thick (most commonly 4-6 m), beginning with a sharp, erosional base overlain by sandstones that contain clasts of claystone, coal, coalified wood and occasional pebbles at the base (Figs 9A, 10B, 11A, B). The sandstones, which fine weakly upwards, are over-

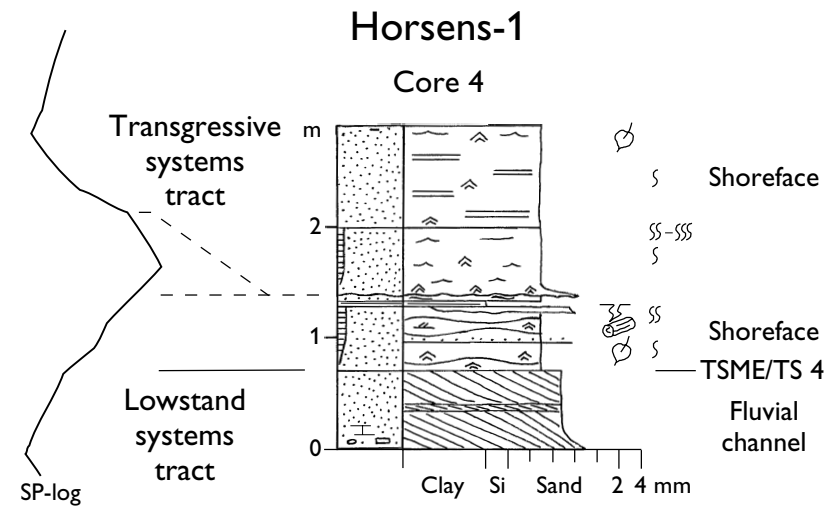

Fig. 6. Core log of the Gassum Formation in the Horsens-1 well. Fluvial sandstones (LST) are overlain by transgressive shoreface sandstones (TST) of the fourth-order sequence 4 , sequence Vi 1 (core depths are corrected to log depths by subtracting c. $10 \mathrm{~m}$; the slight misfit between core and SP-log is caused by poor recovery of the interbedded offshore mudstones). 
A

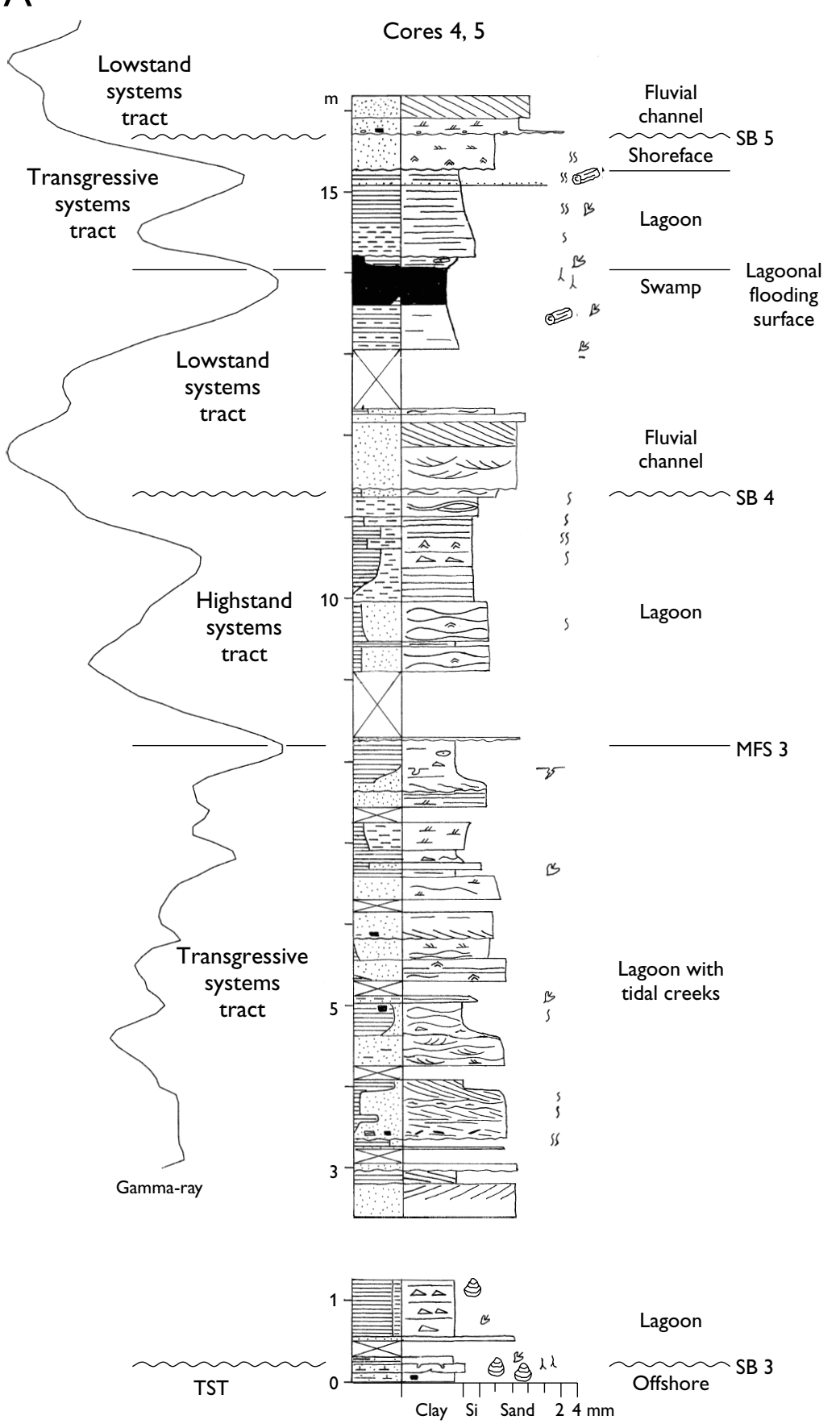

B

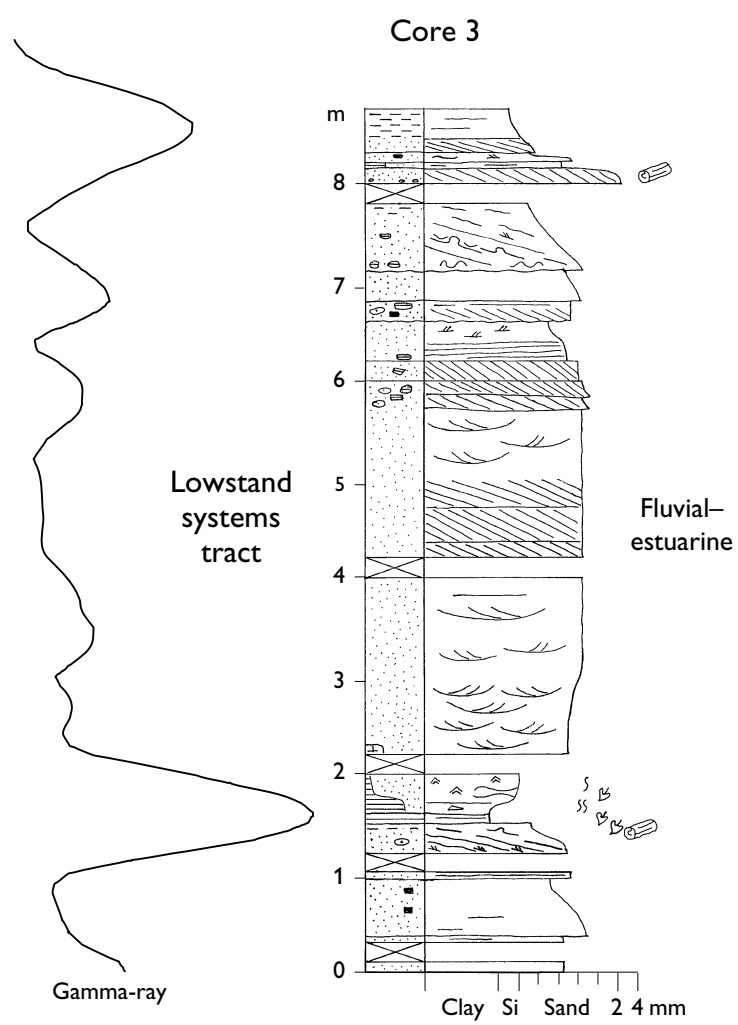

This and facing page:

Fig. 7. Core logs of the Gassum Formation in the Thisted-3 well. Cores 4 and 5 (A) show lagoonal and fluvial deposits of the fourth-order sequences 3 and 4, belonging to the HST of the Vi 1 sequence. Vi 1 is bounded above by SB 5 which is overlain by a LST of fluvial sandstones (A; uppermost core 4) and fluvial-estuarine sandstones with minor mudstones of the fourth-order sequence 5 (B; core 3 ) of the Ga 1 sequence. $\mathbf{C}$ : Core 2 exhibits lagoonal deposits of the TST overlain by a thin HST and shoreface sandstones of the forced regressive systems tract (FRST) of sequence 5, Ga 1 sequence. The upper part of core 2 shows shoreface sandstones (LST) overlain by shoreface to offshore transition zone sandstones and heteroliths of sequence 6 , Ga 1 sequence. For legend, see Fig. 5. lain by highly carbonaceous claystones and coaly beds with roots, or are cut by erosion surfaces overlain by a similar fluvial unit, lacustrine or marine deposits. Palynological samples yield only poor assemblages of spores and pollen (Koch 1983; E.B. Koppelhus and N.E. Poulsen, personal communications 1994; L.H. Nielsen, L. Hamberg and E.B. Koppelhus in: Nielsen 1995). The sandstones are mostly medium- to coarse- grained, occasionally fine-grained, micaceous, carbonaceous, and moderately sorted with subangular to subrounded quartz grains. The colour is typically greyish, occasionally yellowish or brownish. Coarse-grained sand with small quartz pebbles occurs locally in the Haldager Sand Formation. Comminuted organic debris and coalified fragments of leaves, stems and wood occur commonly in both the Haldager Sand and Gassum 
C

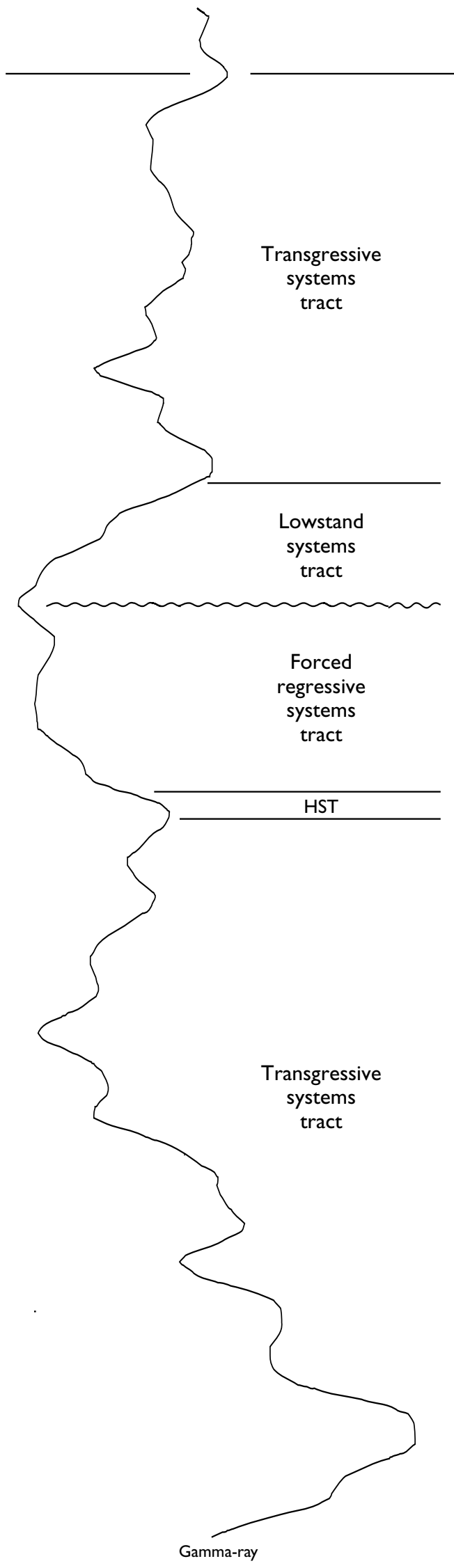

Thisted-3

Core 2

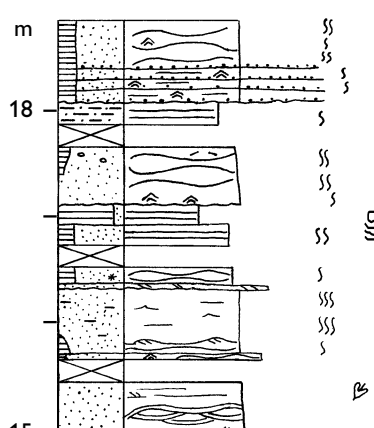

MFS 6

TSME/TS 6

$\sim$ SB 6

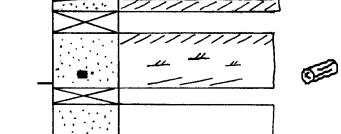

10

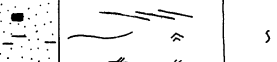

Lower

shoreface

to

offshore

transition

zone

15
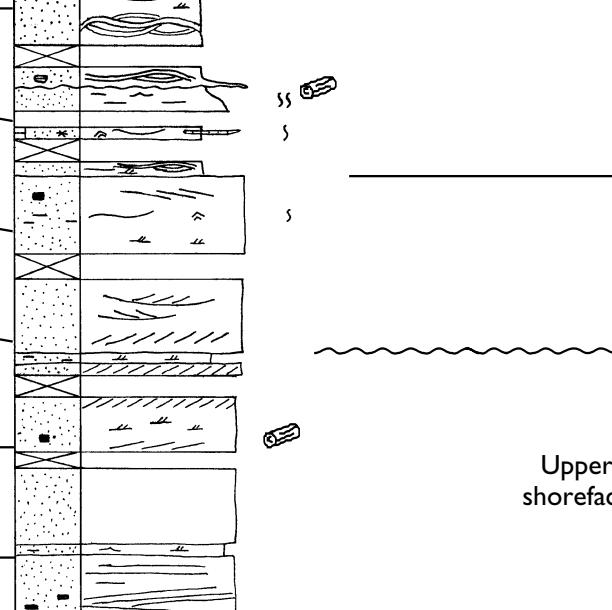

Upper

shoreface

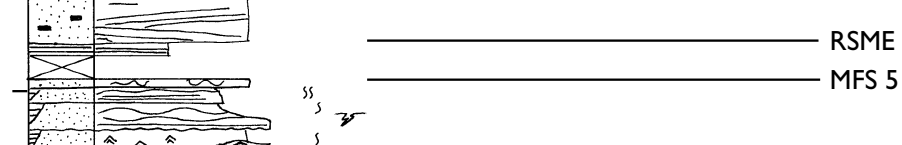

MFS 5
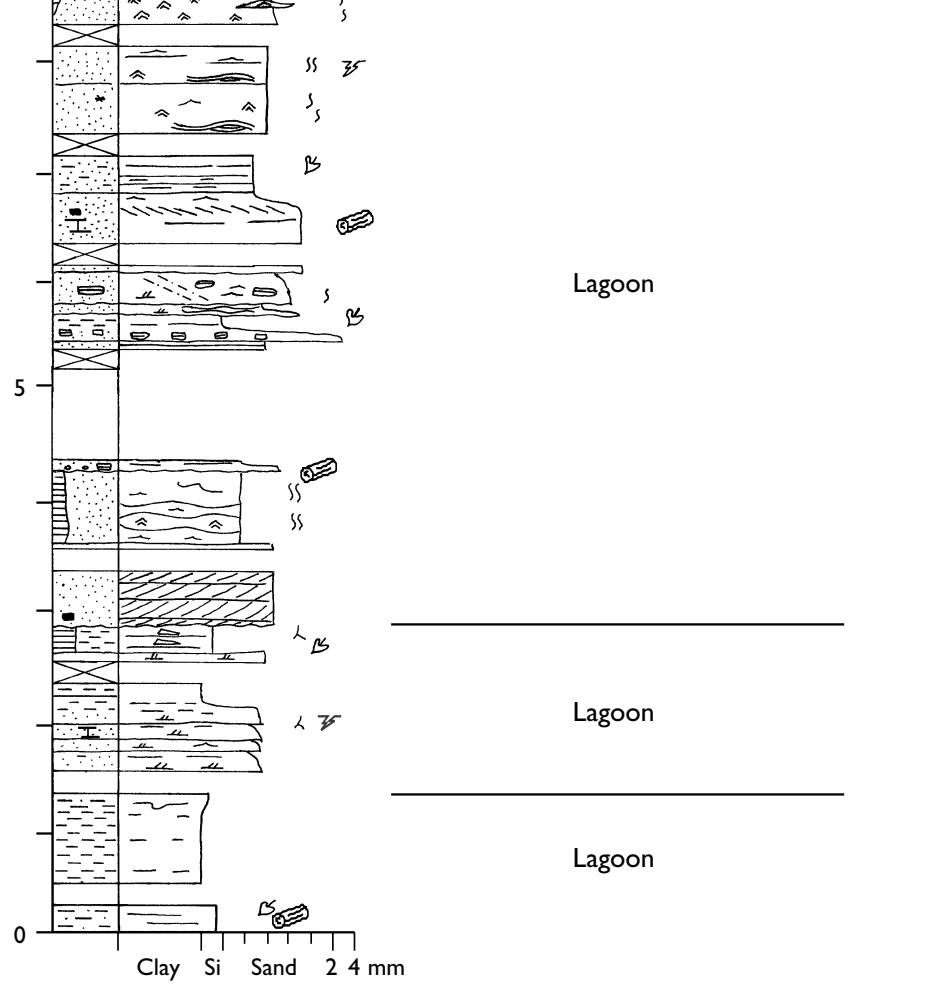

Lagoon

Lagoon

Lagoon 

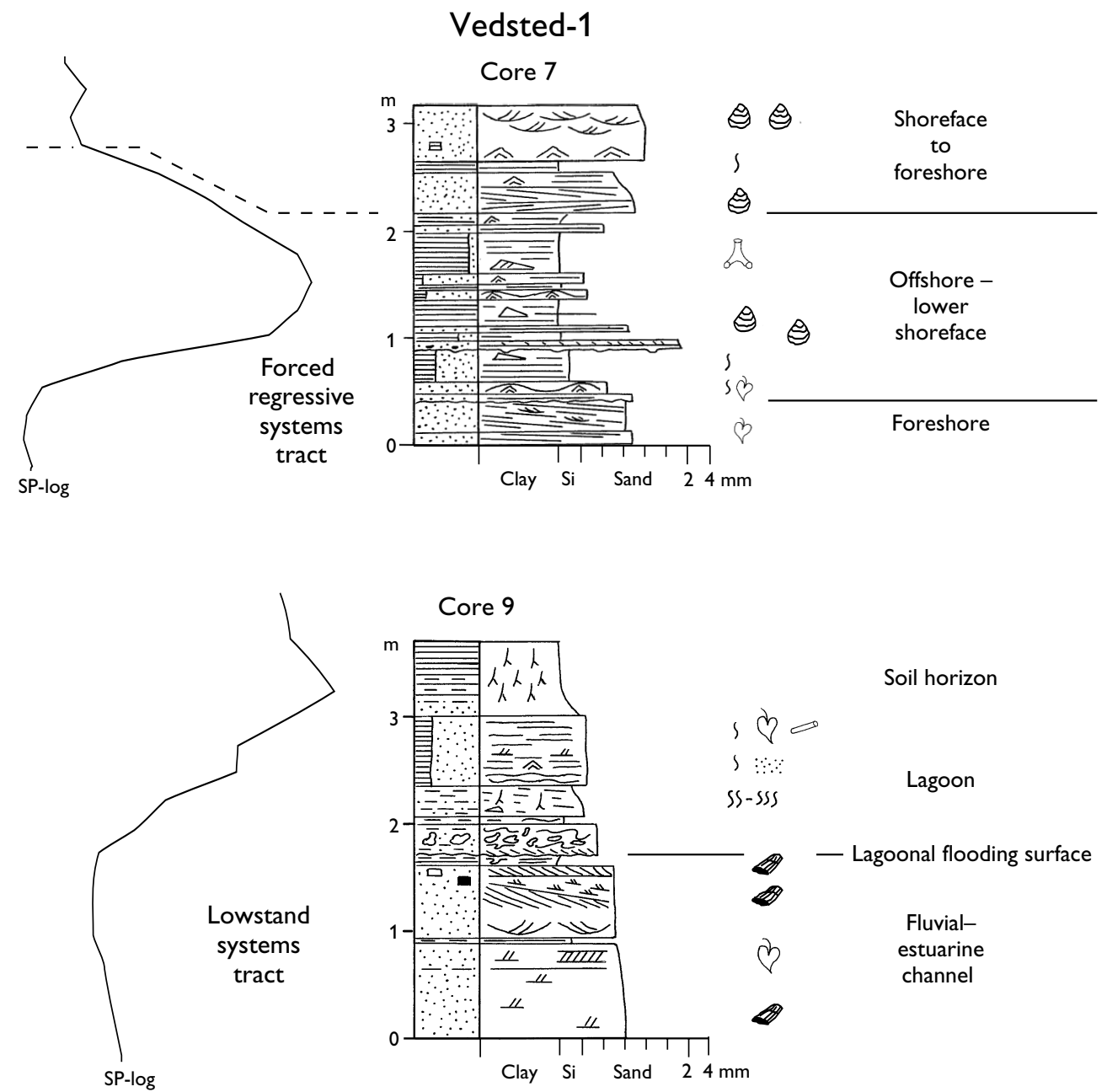

Core 9

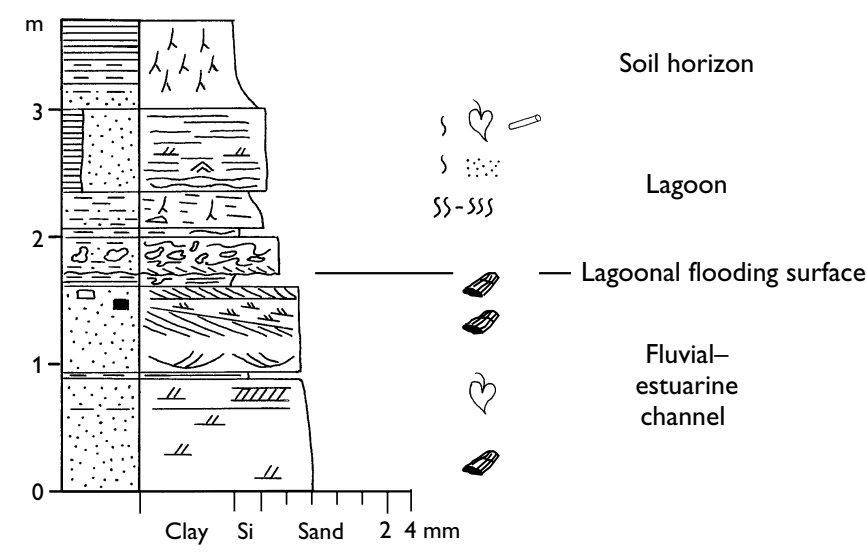

Core 10
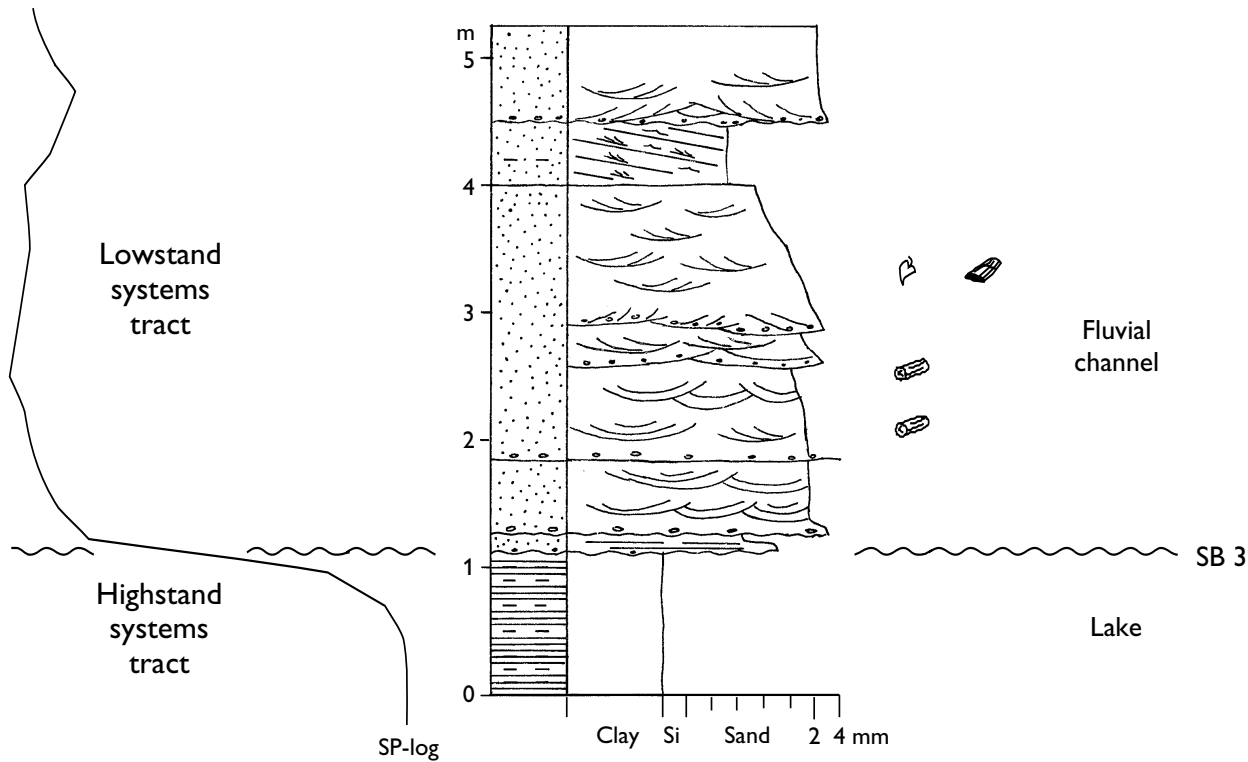
Formations. The sandstones show trough and planar cross-bedding, parallel lamination and cross-lamination. The trough cross-bedded sets are typically $0.05-0.4 \mathrm{~m}$ thick and form cosets $1-4 \mathrm{~m}$ thick. The planar cross-bedded sets are 0.1-1.5 $\mathrm{m}$ thick, and may be isolated or occur in cosets commonly interbedded with trough cross-bedded or parallel-laminated sandstones. Fine-grained, crosslaminated sandstones occur rarely in both formations.

The coarse-grained, pebbly, parallel-laminated beds indicate upper flow regime conditions, while the trough and planar cross-bedding were formed by migrating sinuous and straight-crested dunes under strong currents of the lower flow regime (Harms et al. 1982; Allen 1984). The thick, planar cross-bedded sets represent large bars (Cant \& Walker 1978). The cross-lamination was formed by small ripples driven by weak currents. The fining-upwards units that overlie sharp, erosional bases and consist of cross-bedded cosets and parallellaminated beds, capped by carbonaceous claystones and coal seams, indicate deposition in sandy fluvial channels. This is supported by the occurrence of nonmarine palynomorphs, the absence of marine indicators, and the presence of large plant fragments. The generally high content of dispersed organic debris indicates vegetated interfluve areas. The coarse grain size, the poorly developed fining-upwards trends and the general scarcity of small-scale structures and fine-grained material suggest deposition in braided streams rather than meandering or anastomosing channels (Allen 1965; Miall 1977; Smith 1983). The log-patterns indicate that several thin channel units amalgamate to form fluvial sandstone units up to $25 \mathrm{~m}$ thick in both the Gassum and Haldager Sand Formations in the Fjerritslev Trough and up to $12 \mathrm{~m}$ thick units on the Skagerrak-Kattegat Platform.

\section{Facing page:}

Fig. 8. Core logs of the Skagerrak and Gassum Formations in the Vedsted-1 well. Core 10, within the Vi 1 sequence (Skagerrak Formation) shows lacustrine mudstones (fourthorder sequence 2 ) erosionally overlain by fluvial sandstones that are very coarse-grained and pebbly with rock fragments, weathered feldspars and claystone clasts (LST of sequence 3). Core 9 (Ga 1 sequence) shows fluvial-estuarine and lagoonal deposits of the late LST of the fourth-order sequence 5 (core depths are corrected to $\log$ depths by subtracting $c .6 \mathrm{~m}$ ). Core 7 shows parts of two forestepping parasequences with marine sandstones and mudstones belonging to the FRST of sequence Fj 2 (core depth is corrected to log depth by subtracting c. 5 $\mathrm{m}$; slight misfit between core and log signal is caused by poor core recovery). For location of the Vedsted- 1 cores, refer to Figs 19, 20; For legend, see Fig. 5.

\section{Lacustrine facies association}

In the Gassum Formation, this association is primarily identified in the Flyvbjerg- 1 and Vedsted-1 wells in the Fjerritslev Trough (Fig. 12), but was also cored in Gassum-1 (Fig. 13C). It is uncommon in the Haldager Sand Formation where it was cored in the Fars $\varnothing-1$ and Skagen-2 wells (Fig. 10B).

In the Gassum Formation, the association primarily consists of massive to poorly laminated, micaceous and weakly carbonaceous, silty and dark grey mudstones forming units 7-26 $\mathrm{m}$ thick. Variegated mudstones occur in the lower part of the formation. Similar mudstones are present in the uppermost part of the Skagerrak Formation (Frederikshavn-1 and -2, Skagen-2, Vedsted-1; Fig. 8). In the Haldager Sand Formation, the association consists of grey to dark grey siltstones and mudstones with parallel lamination, lenticular bedding and scattered cross-lamination. The palynomorph assemblages are very poor and non-marine (Bertelsen 1978; Koch 1983; L.H. Nielsen, L. Hamberg and E.B. Koppelhus in: Nielsen 1995).

The structures and the fine grain size indicate deposition mainly from suspension, and the palynomorphs indicate freshwater conditions. The change from variegated claystones to greyish and more carbonaceous claystones reflects the general change in climate from hot and arid in the Triassic to warm and humid in the Jurassic.

\section{Estuarine channel facies association}

This facies association is common in the Gassum Formation, where it was cored in the Børglum-1, Gassum-1, Stenlille-1 and - 6 , Thisted- 3 and Vedsted-1 wells (Figs 5, 7, 8, 14). It consists of erosionally-based, fining-upwards units, 5-25 m thick, locally capped by coal or heteroliths with rootlets.

Cores from the Børglum, Thisted and Vedsted wells mainly show cross-bedded, fine- to medium-grained, occasionally coarse-grained sandstones. They commonly contain abundant mudstone clasts, comminuted organic debris and fragments of leaves and stems, probably of the genus Equisetites. Thin mudstone drapes and ripple-foreset laminae occur in places. The palynomorph assemblages contain the alga Botryococcus sp., the dinoflagellate Dapcodinium priscum and the acritarch Micrbystridium sp. (L.H. Nielsen, L. Hamberg and E.B. Koppelhus in: Nielsen 1995).

The thickest and best developed succession is from Stenlille-1 where cores show fine-grained, cross-bedded 
A

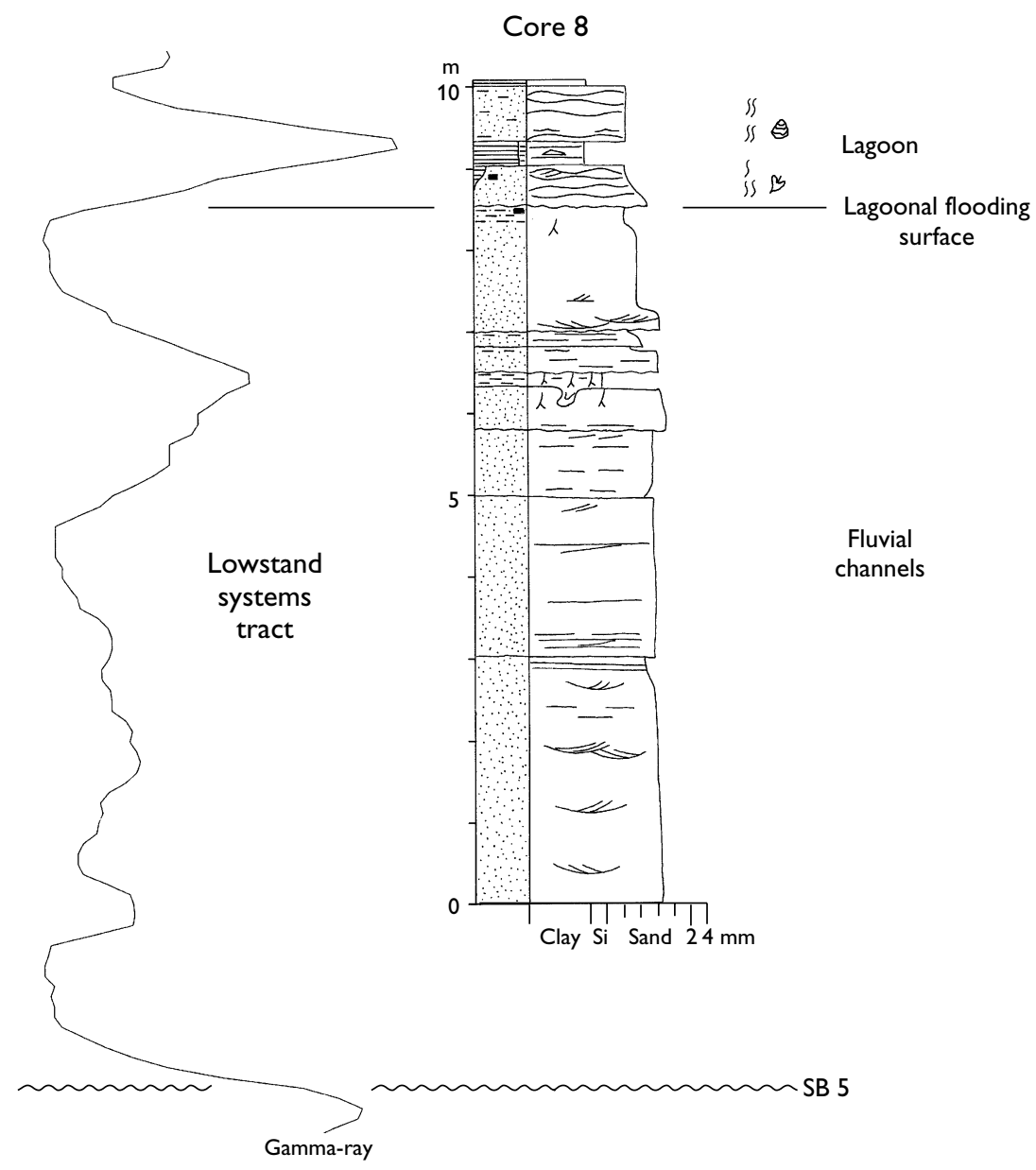

Core 9

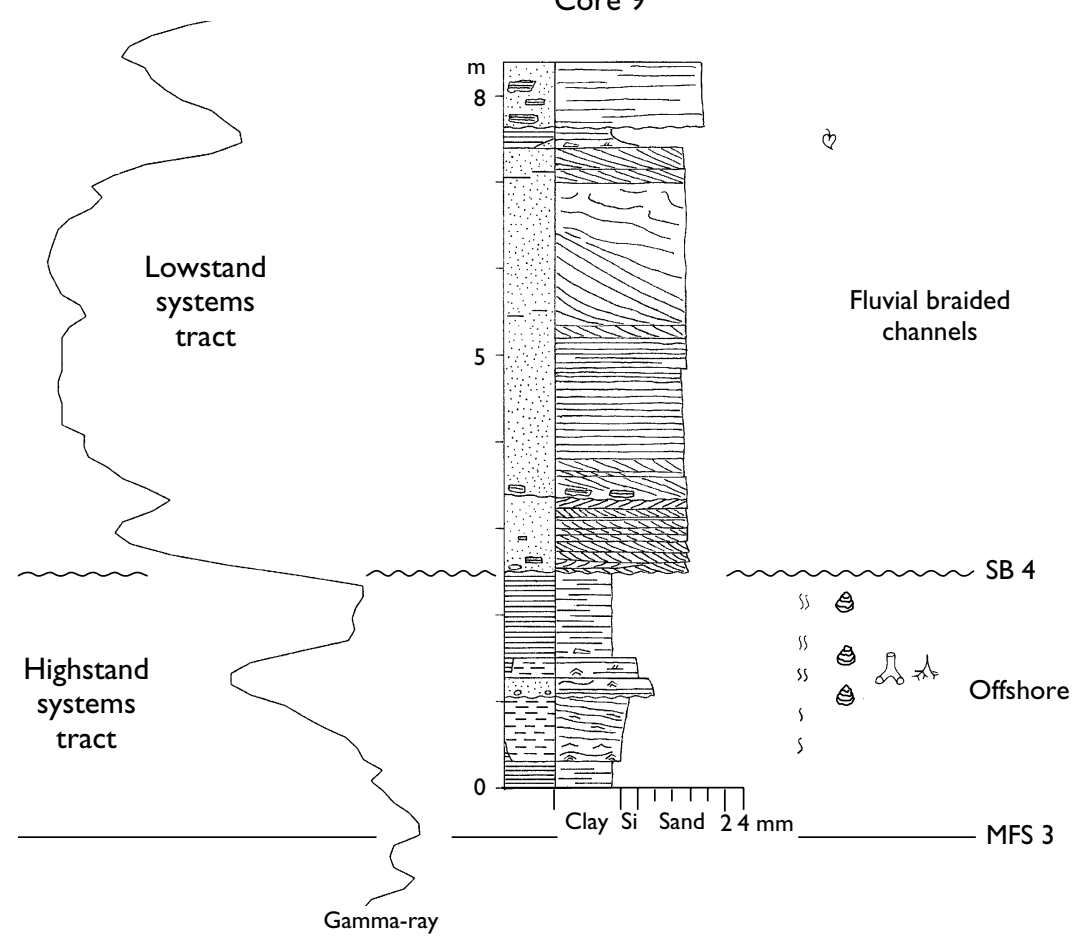


B

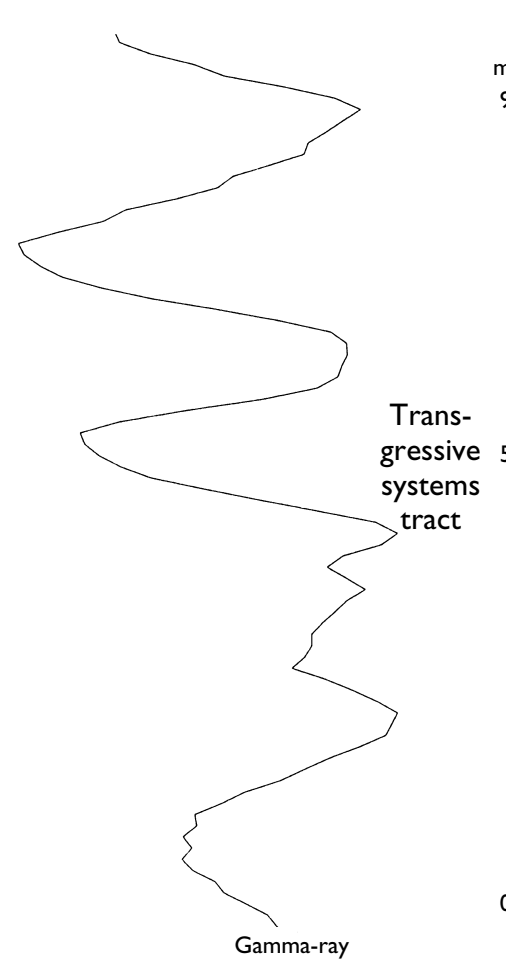

Års-1

Core 6

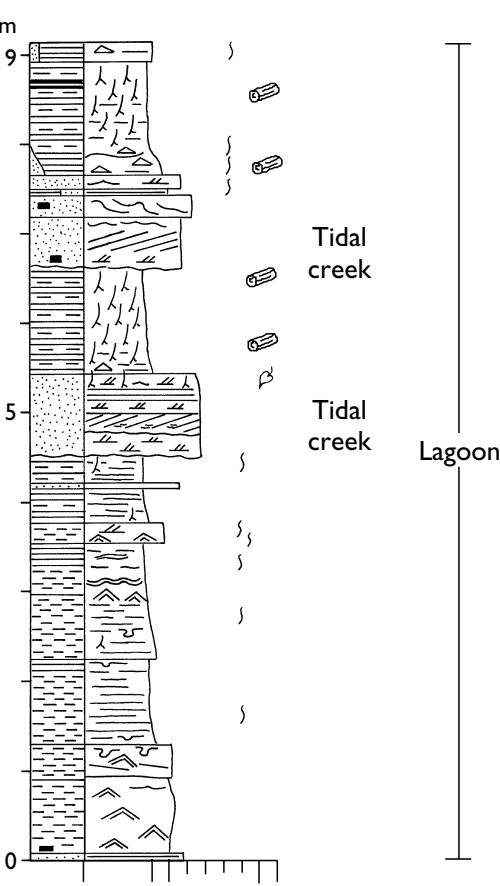

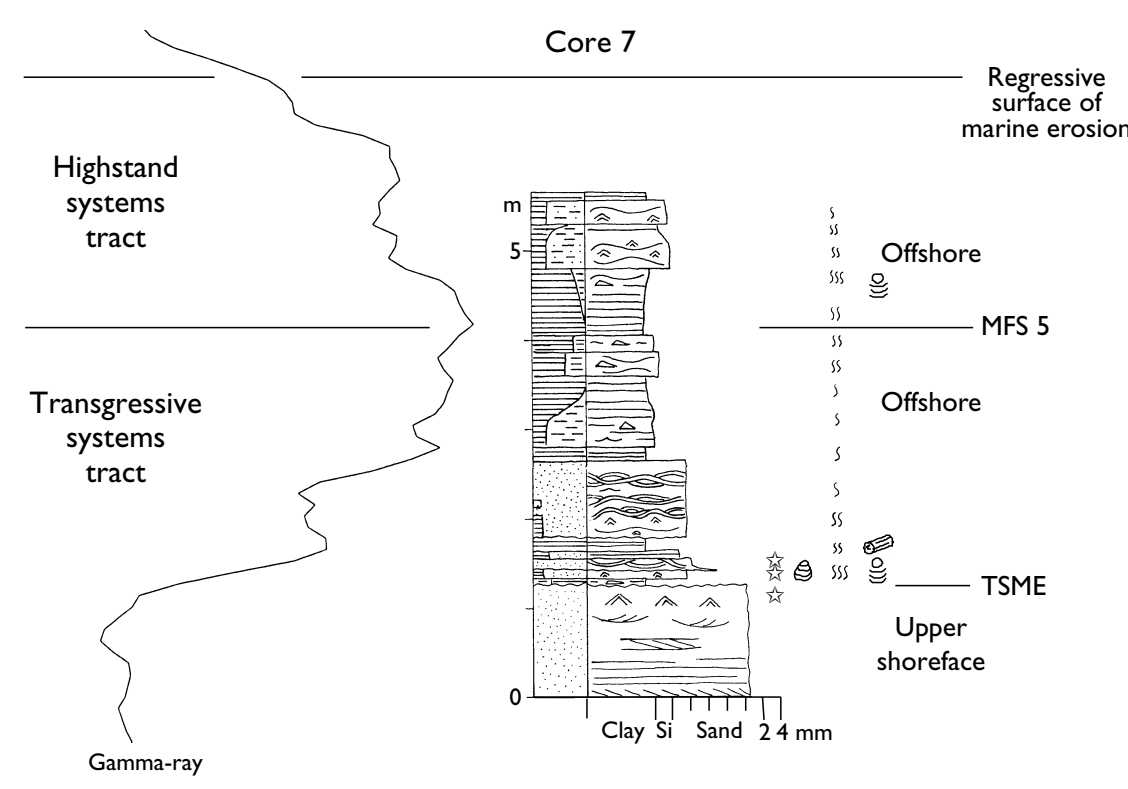

This and facing page:

Fig. 9. Core logs of the Gassum Formation in the Års-1 well. A: Core 9, within the Vi 1 third-order sequence, shows marine mudstones and sandstones (HST) of the fourth-order sequence 3 erosionally overlain by cross-bedded, coarse-grained fluvial sandstones with abundant mudstone clasts and organic debris at the base constituting the LST of the fourth-order sequence 4 (see Fig. 11A). Core 8 shows fluvial sandstones of the fourth-order sequence 5 ( $\mathrm{Ga} 1$ sequence) overlain by transgressive lagoonal deposits. B: Core 7 shows marine deposits of sequence 5 ( $\mathrm{Ga} 1$ sequence). Note the well-defined backstepping and forestepping pattern defining MFS 5, and a sharply developed transgressive surface of marine erosion (shown in Fig. 11D). Core 6 illustrates lagoonal mudstones and sandstones overlying estuarine deposits (below core) of the late LST of sequence Fj 1. For legend, see Fig. 5. 


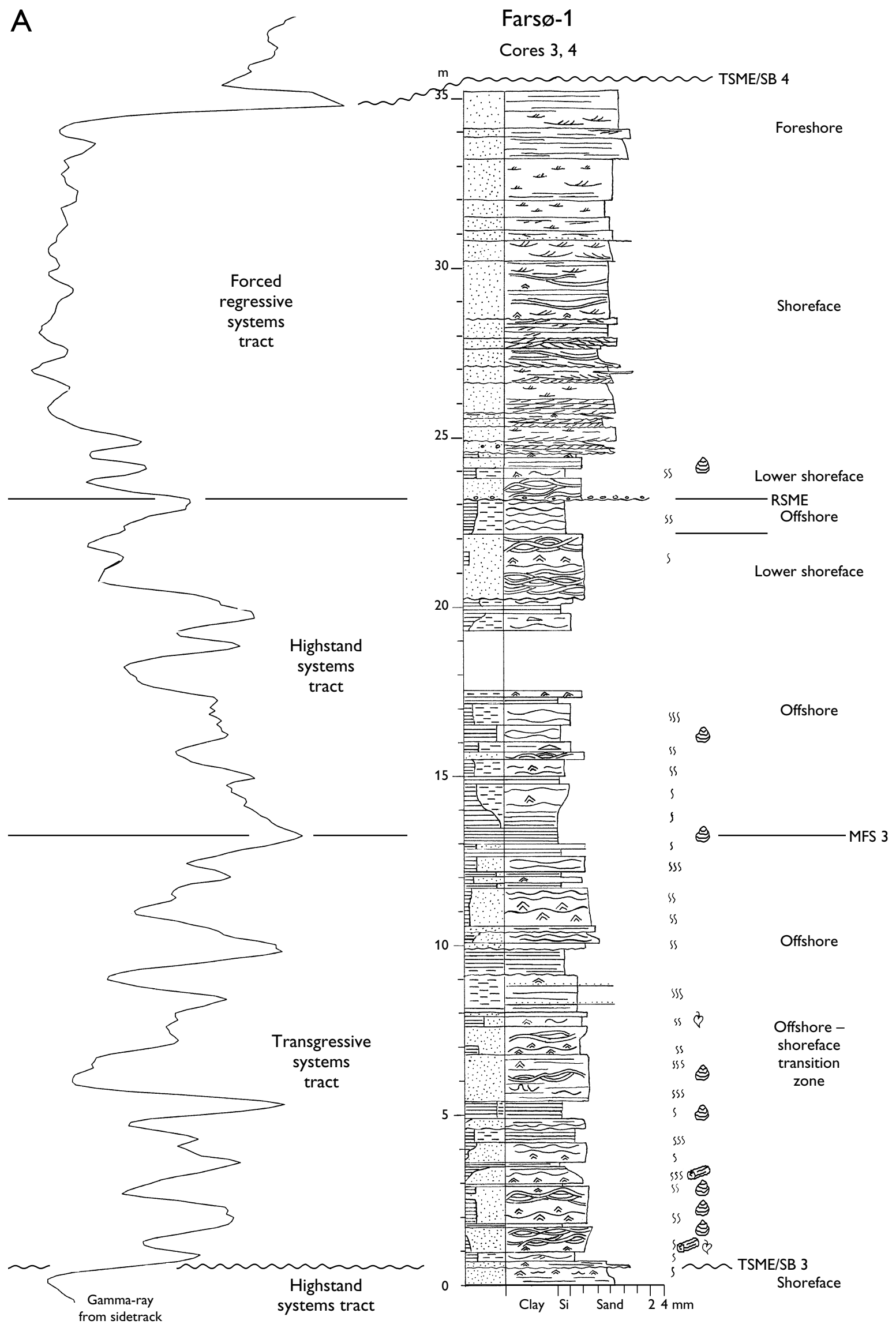


B

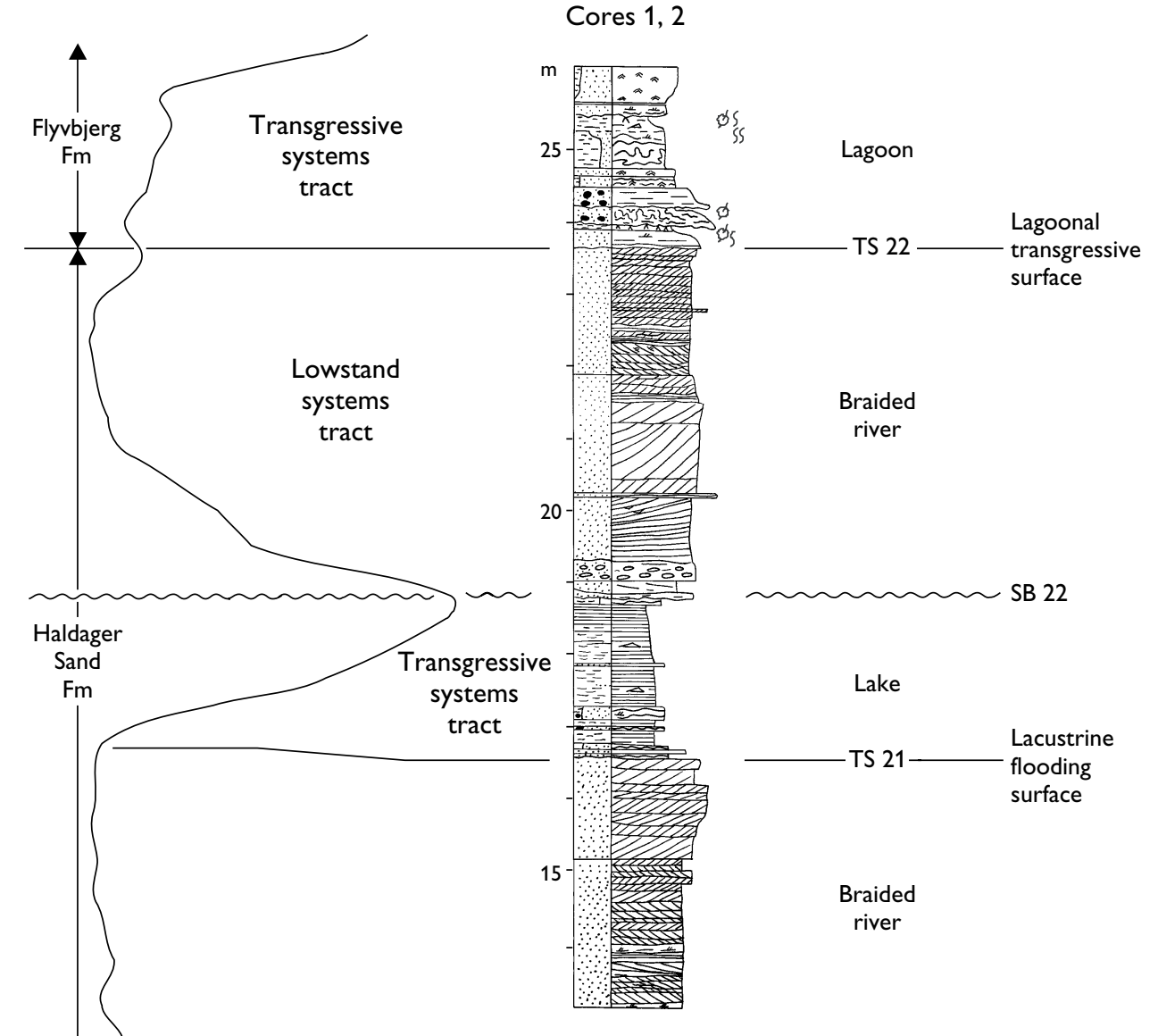

Farsø-1

\section{Cores 1,2}

This and facing page:

Fig. 10. Core logs of the Gassum, Fjerritslev, Haldager Sand and Flyvbjerg Formations in the Farsø-1 well. A: Cores 3 and 4 show marine shoreface to offshore deposits of the TST, HST and FRST of the fourth-order sequence 3 of the Vi 1 sequence (see Fig. 19). A core photo of the base of the FRST is shown in Fig. 11C. B: Cores 1 and 2 show offshore marine mudstones of sequence $\mathrm{Fj} 9$ erosionally overlain by fluvial sandstones (LST) and lacustrine mudstones (TST) of sequence Ha

SB (19-20) 213 (see Fig. 24). The base of the fluvial sandstones marks the 'base Middle Jurassic unconformity' (see core photo in Fig. 11B). The upper part of the core shows fluvial sandstones (LST) and transgressive lagoonal deposits (TST) of sequence Fl 1. Modified from Koch (1983). For legend, see Fig. 5. 

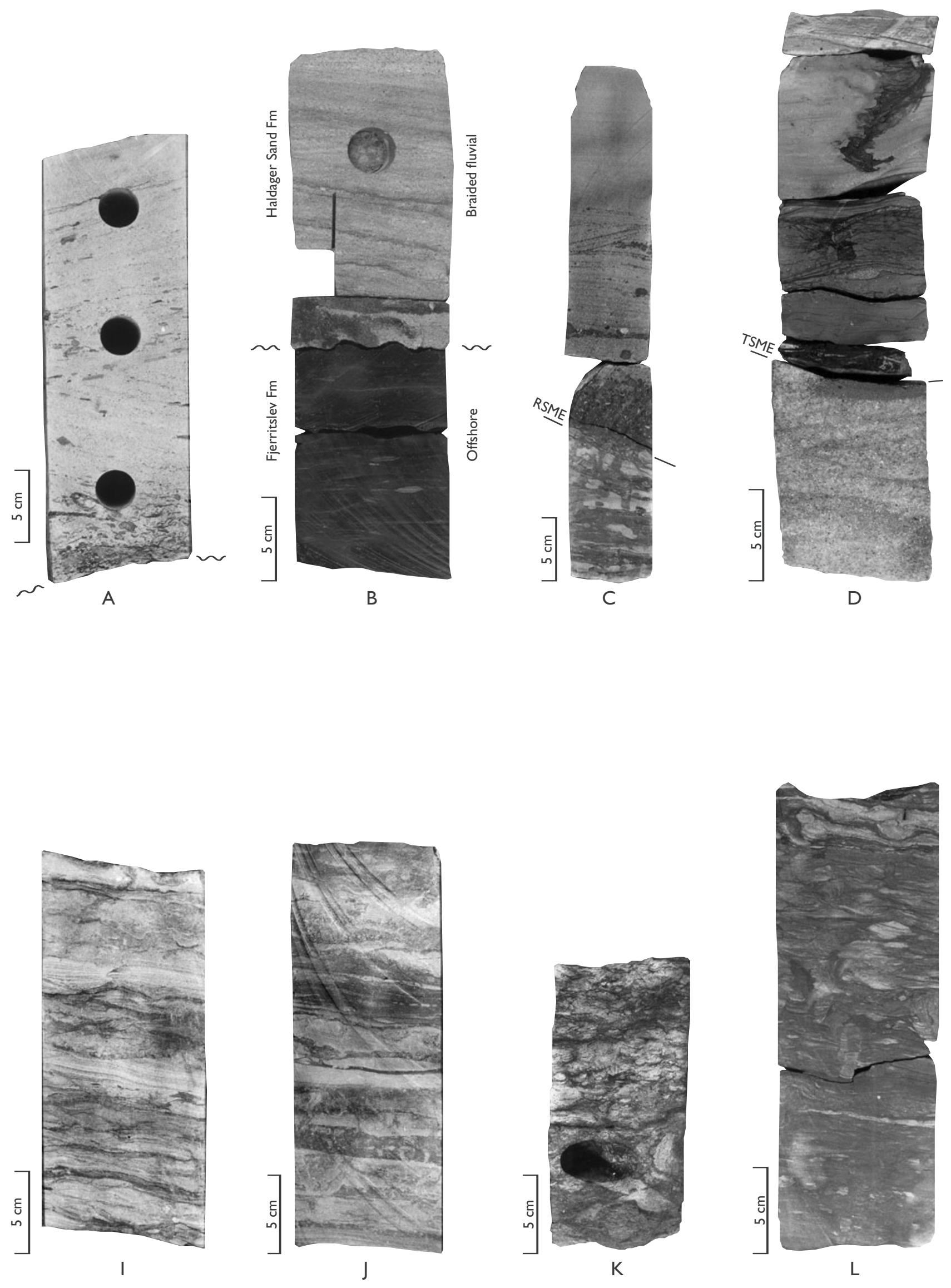


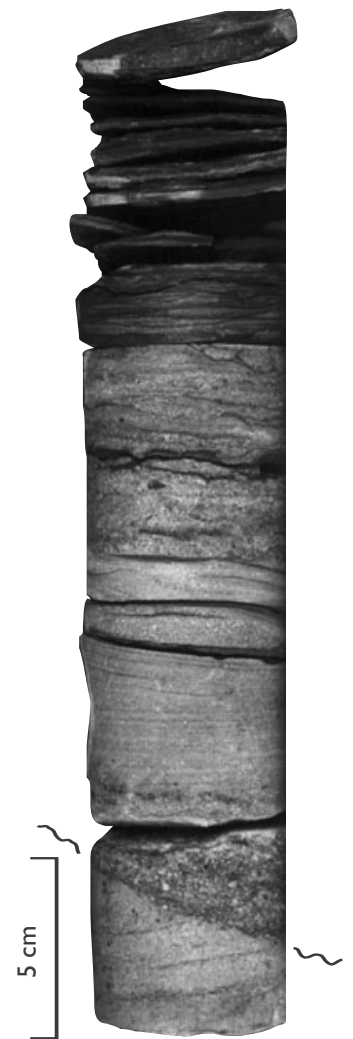

E

\section{E⿱一⿻上丨⿱⿰㇒一乂}

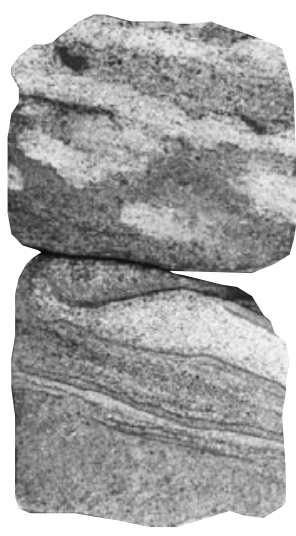

F

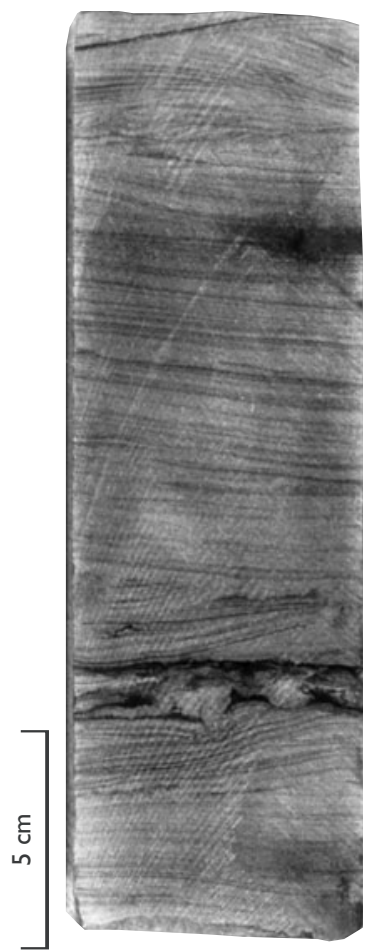

G

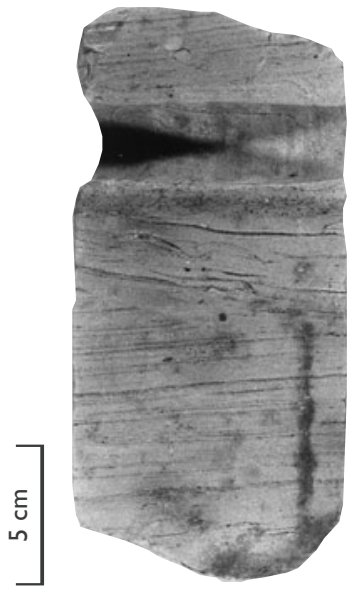

$\mathrm{H}$
Fig. 11. Core photos exhibiting the main facies of the Upper Triassic - Jurassic in the Danish Basin. A: Coarse-grained fluvial sandstones with abundant mudstone clasts and organic debris; the base of this core piece is an erosional surface defining SB 4. Års-1, core 9, Gassum Formation (Fig. 9A). B: Cross-bedded fluvial sandstones of the Haldager Sand Formation erosionally overlying marine mudstones of sequence Fj 9, (Fjerritslev Formation, F-IV member) marking the 'base Middle Jurassic unconformity', consisting of the amalgamated sequence boundaries SB 19-21. Fars $\varnothing-1$, core 2 (see Figs 10, 24). C: Hummocky cross-stratified shoreface sandstones with siderite-cemented clasts sharply overlying offshore bioturbated silty mudstones; the boundary represents a regressive surface of marine erosion (RSME) at the base of the FRST of the fourth-order sequence 3 (Vi 1 thirdorder sequence). Fars $\varnothing-1$, core 3, Gassum Formation (Fig. 10A, 23.2 m). D: Coarse-grained, cross-bedded shoreface sandstones with abundant pyrite aggregates, capped sharply by a transgressive surface of marine erosion (TSME) overlain by burrowed sandstones (Teichichnus) with swaley cross-stratification, sandy fossiliferous heteroliths with waveripple lamination and mudstones. Års-1, core 7, Gassum Formation (Fig. 9B, 1.2 m). E: The lowermost $2-3 \mathrm{~cm}$ of the illustrated core consists of shoreface sandstones of the HST of sequence 2 , which is erosionally capped by TSME/SB 3 overlain by a thin veneer of coarsegrained sandstone and laminated and wave-rippled, fine-grained sandstones; these pass upwards into wavy and lenticular bedded mudstones with laminae and lenses of finegrained sandstones. Fars $\varnothing-1$, core 4, Gassum Formation (see Fig. 10A, 0.5 m). F: Top of calcite-cemented shoreface sandstones with shell fragments forming the LST of sequence 3 (Vi 1 third-order sequence). Gassum-1 well, Gassum Formation (Fig. 13A, 26.5 m). G: Finegrained, swaley cross-stratified and wave-rippled sandstones of the TST of sequence 3 . Farsø-1, Gassum Formation (Fig. 10A, 7.2 m). H: Two sets of swaley cross-stratified, finegrained sandstones, the upper set containing abundant organic debris and shell fragments in the lower part. Børglum-1, core 20, Gassum Formation, HST of Fj 1 (Fig. 5, 0.7 m; see also Fig. 20). I-L: Fine-grained heteroliths of the offshore to shoreface transition zone showing a variable degree of wave-reworking and bioturbation. Gassum Formation. M: Weakly laminated to homogenous, offshore mudstones with thin-shelled bivalves marking MFS 3, sequence 3 of Vi 1. Farsø-1, Gassum Formation (Fig. 10A, 13.2 m). 
Flyvbjerg-1

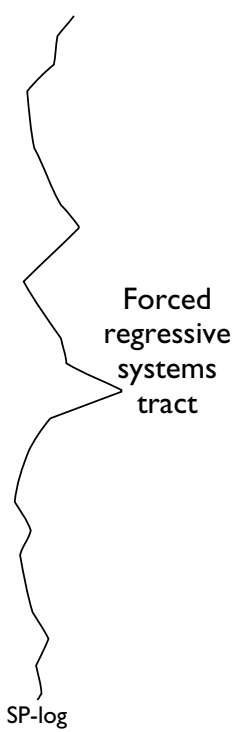

\section{Core 6}

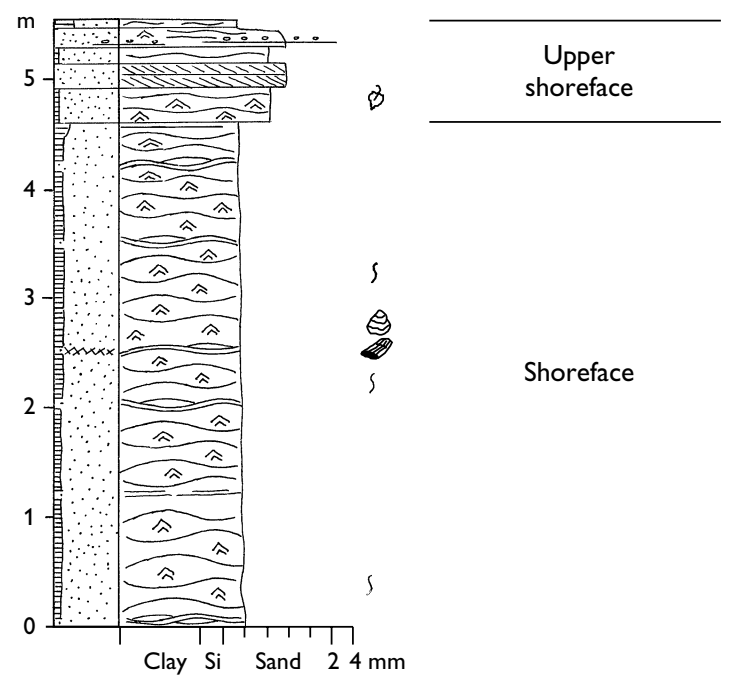

\section{Core 7}

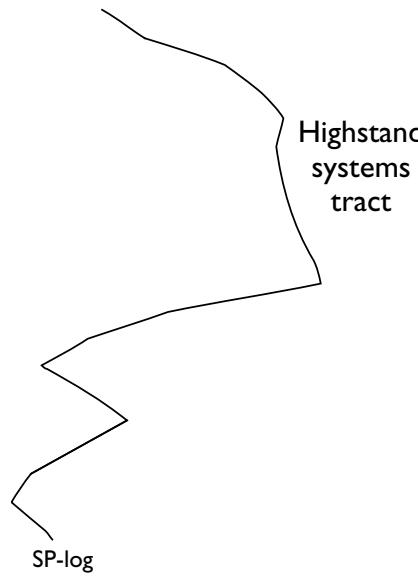

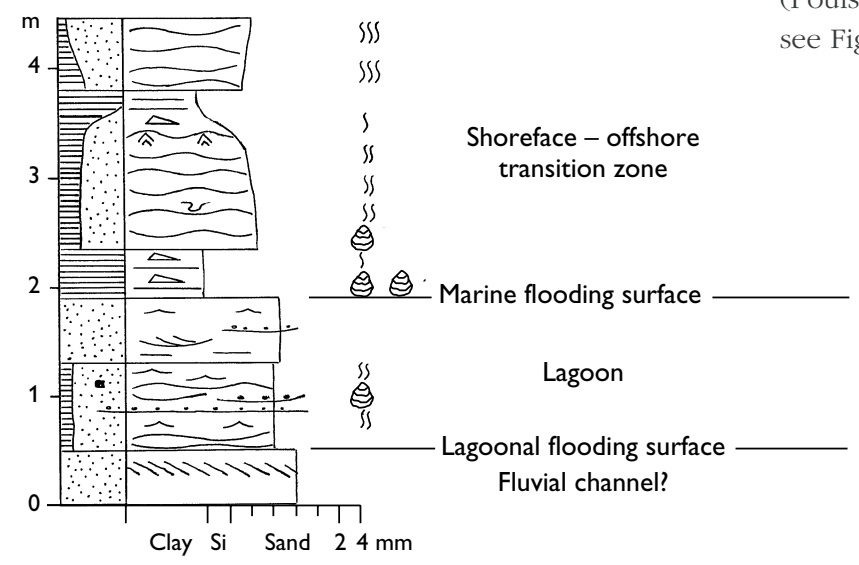

Fig. 12. Core logs of the Gassum Formation in the Flyvbjerg-1 well. Core 8 shows lagoonal and lacustrine deposits (TST) of the fourth-order sequence 7 of Ga 1 (see Fig. 19). Core 7 shows fluvial sandstones overlain by lagoonal sandstones and marine heteroliths of the highly variable HST of sequence Fj 1 (see Fig. 20). Core samples yielded ostracods, dinoflagellate cysts, spores and pollen indicating a Hettangian age (Michelsen 1975; Poulsen 1992b). Core 6 shows shoreface sandstones of the FRST of sequence Fj 2; core samples yielded spores and pollen of the Sinemurian C. macroverrucosus Zone (Poulsen 1992b). For legend, ee Fig. 5.

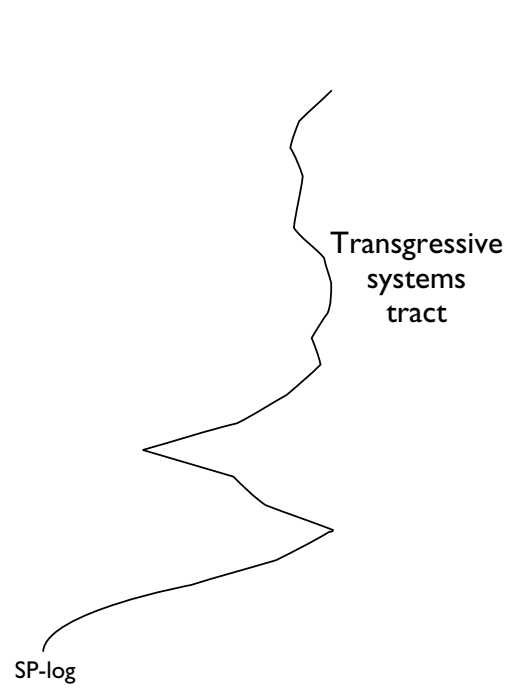

\section{Core 8}

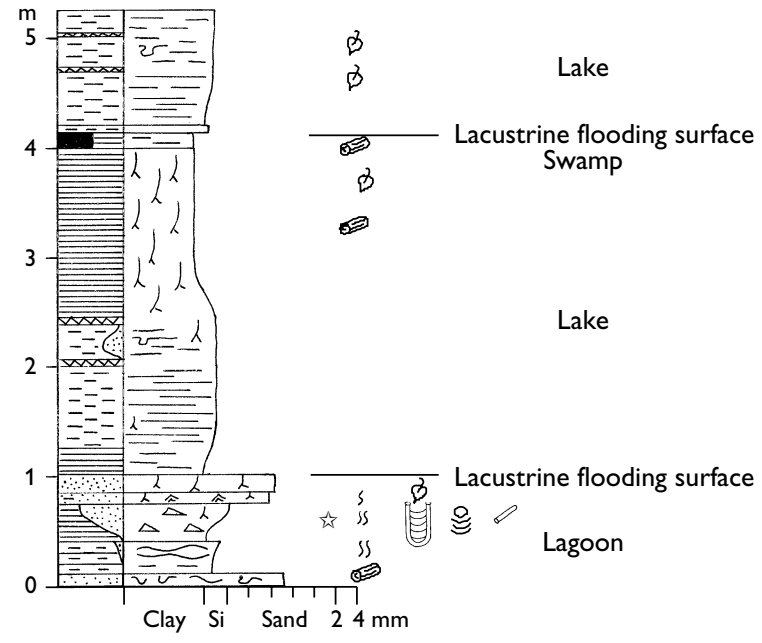




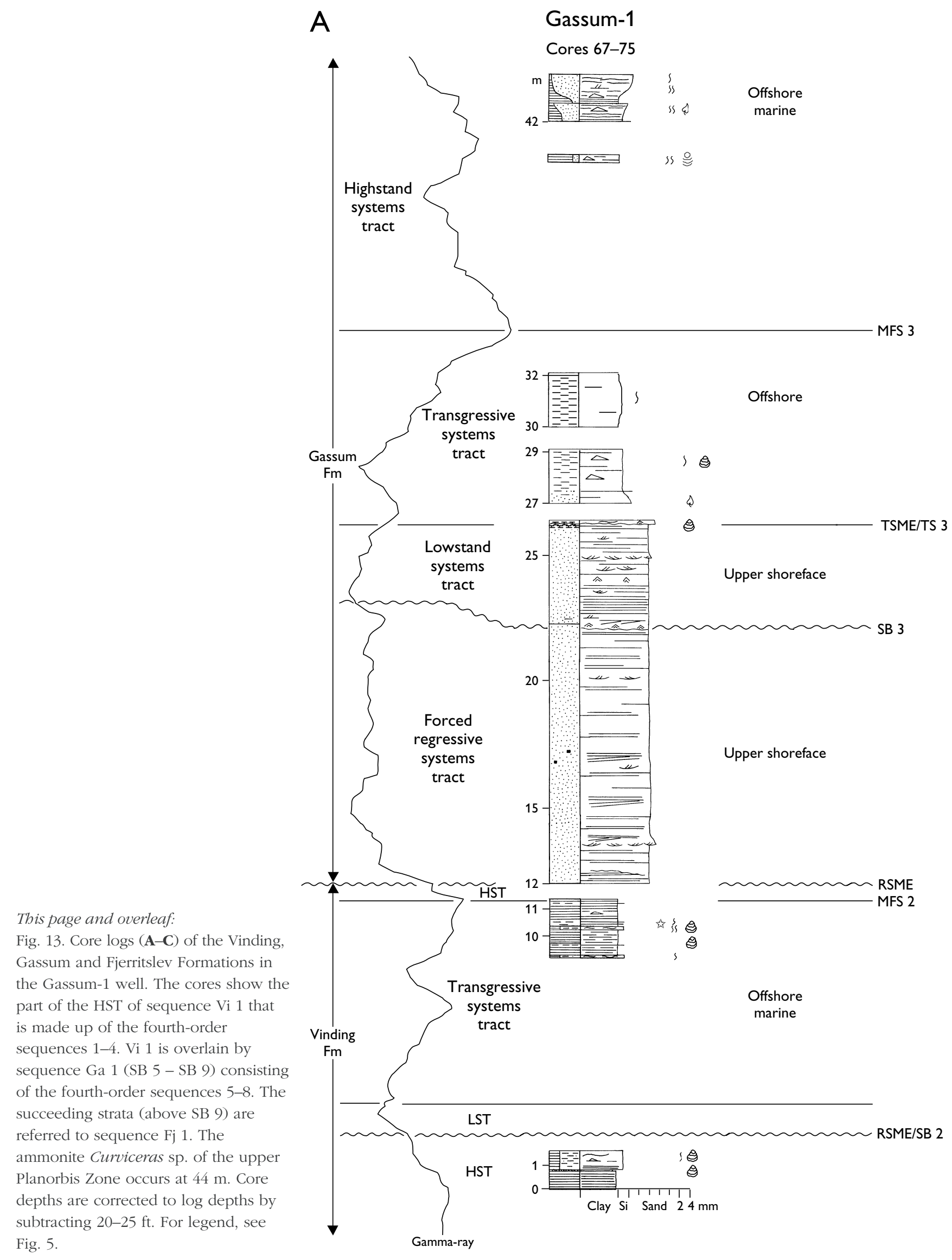


B

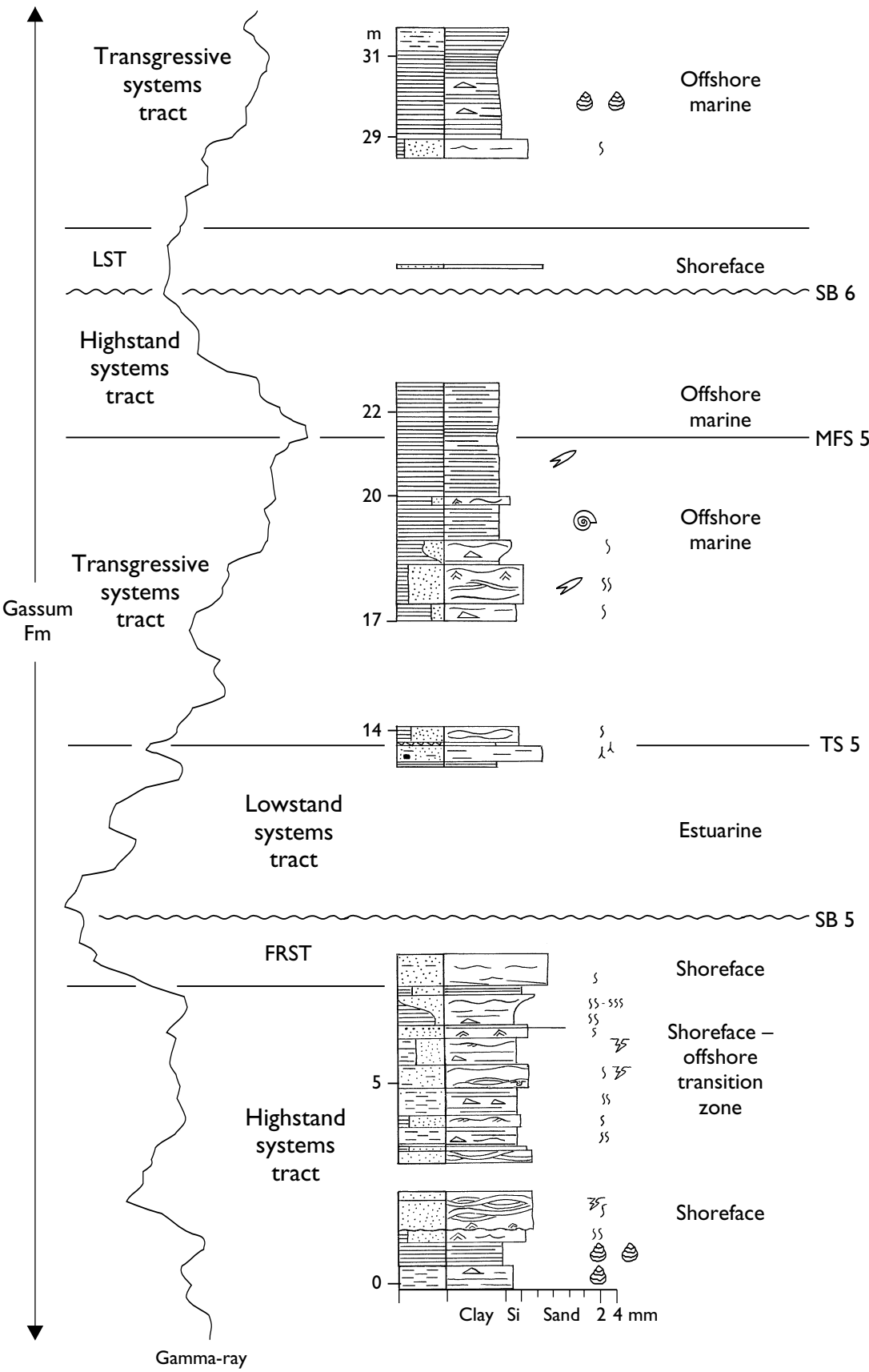

Gassum-1

Core 57-66

\section{Core 57-66}


C

$\uparrow$

Fjerritslev

$\mathrm{Fm}$

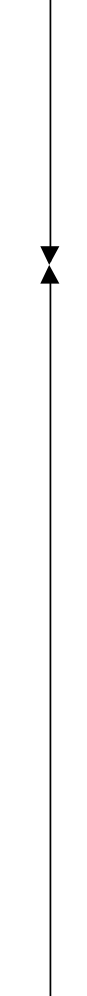

Gassum

$\mathrm{Fm}$

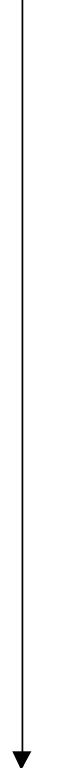

Gassum-1

Core 52-56

$\mathrm{m}$

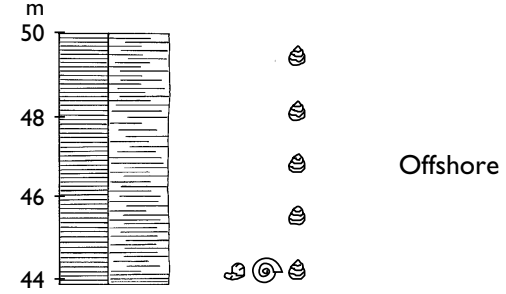

Transgressive

systems

tract

Shoreface

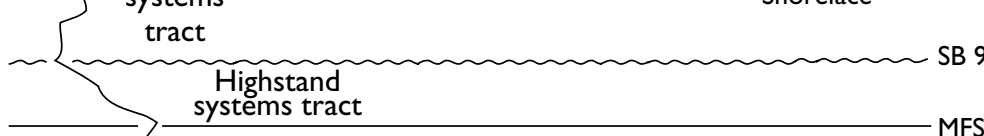

FS 8
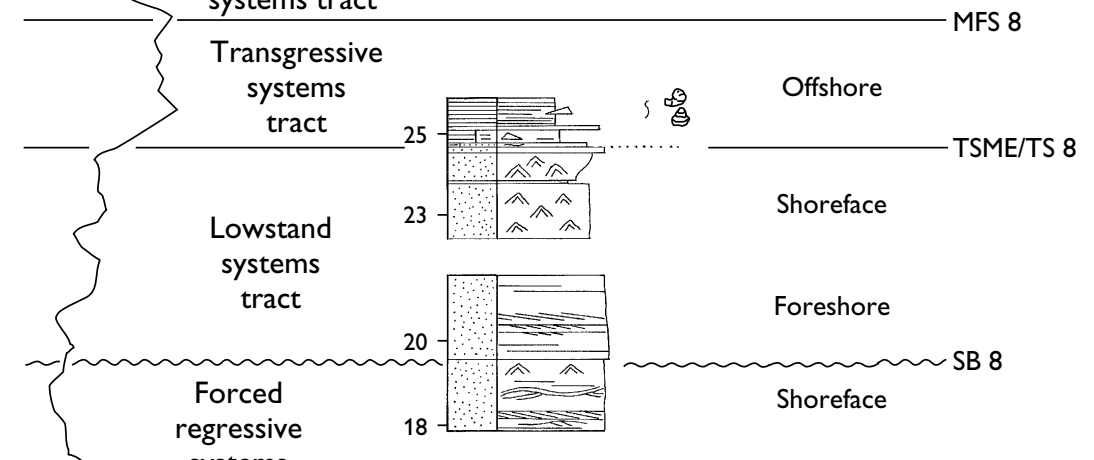

regressiv

systems
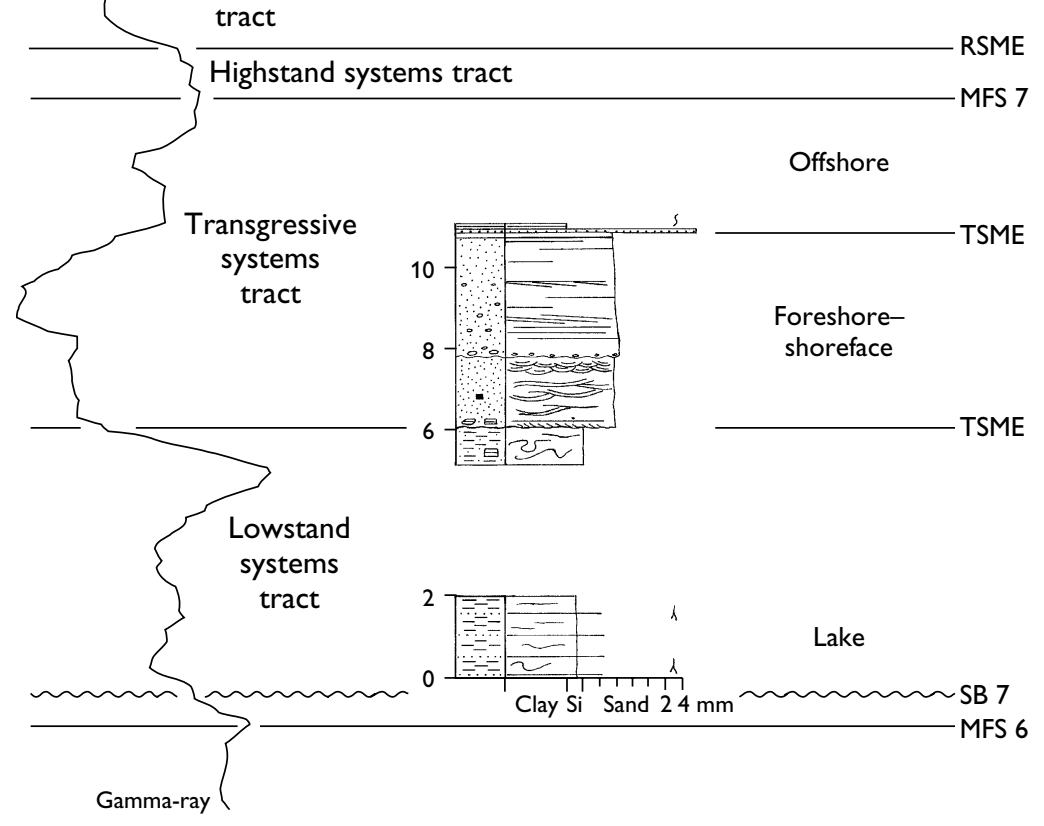


\section{Stenlille-1}

Cores 9, 10

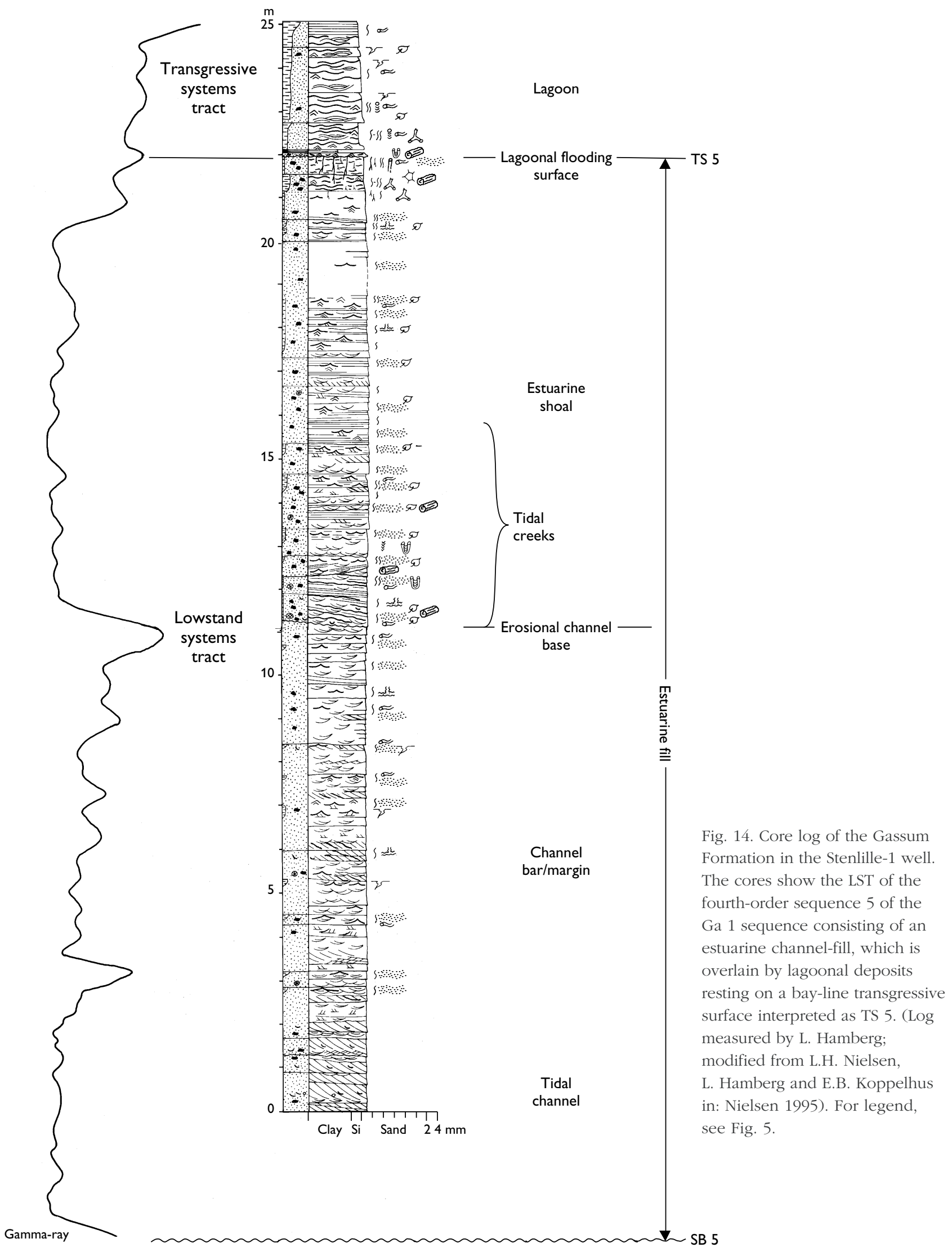


sandstones with carbonaceous debris and common mudstone drapes on foresets, occasionally forming couplets (Nielsen et al. 1989; Hamberg 1994; L.H. Nielsen, L. Hamberg and E.B. Koppelhus in: Nielsen 1995). The foresets are commonly tangential and pass into cross-laminated bottomsets. Ripples occur locally in the lower part of the foresets with foreset laminae dipping in the opposite direction to the larger foresets. Interbedded with the cross-beds are flaser to wavy bedded heterolithic beds, $2-15 \mathrm{~cm}$ thick, with erosional bases and sharp boundaries between ripple-laminated, non-graded sandstone layers and mudstone drapes. Upwards in the succession, the cross-beds are overlain by fining-upwards beds, $10-25 \mathrm{~cm}$ thick, with small, cross-bedded sets that progressively decrease in thickness to ripple-lamination capped by mudstone or flaser bedding. Higher in the section, erosionally based beds show inclined heteroliths of thinly interlaminated, carbonaceous sandstone and mudstone. The inclined heteroliths are overlain by weakly fining-upwards units with erosional bases showing ripple-lamination, parallel lamination and flaser bedding. These units and the inclined heteroliths are burrowed and contain abundant comminuted organic debris, and fragments of leaves, wood and probable Equisetites sp. stems. The overlying, slightly heterolithic and burrowed sandstones show mainly parallel lamination and muddraped wave-ripple lamination. The succession ends in a burrowed, muddy layer with Ophiomorpha isp., rootlets, stems and desiccation cracks.

The mixed marine and freshwater palynomorph assemblages, burrowing, abundant plant material, rootlets and coal seams indicate a brackish-marine environment with fluvial influx. The regular occurrence of foreset drapes reflects tidal influence during deposition, and couplets indicate subtidal conditions (Visser 1980; Banerjee 1989). The cross-beds were formed by migrating transverse bedforms during dominant tidal currents, while the ripple-laminated sand enclosed by mud couplets reflects deposition by the oppositely directed, subordinate and weaker current causing ripple migration up the slipface of the larger bedforms (Boersma \& Terwindt 1981; Terwindt 1981). Deposition is thus interpreted as having taken place in channels with relatively strong tidal currents. The sharp boundaries between the sandstones and the mudstone partings in the heteroliths indicate a settling time-lag of mud relative to sand deposition, which is characteristic of tidal heteroliths (van Straaten \& Kuenen 1957; Little-Gadow \& Reineck 1974), and the heteroliths are interpreted as tidal flat deposits. The increase upwards in the proportion of mud reflects progradation of the tidal flats. The bioturbated, inclined heterolithic bedding is inter- preted to have formed by lateral accretion on point bars in intertidal creeks (Allen 1965; Barwis 1978; Thomas et al. 1987; Smith 1988). The uppermost heteroliths and mudstones with rootlets in the Stenlille- 1 core reflect upwards shallowing and eventual subaerial exposure. Log correlation between closely spaced wells at Stenlille indicate the presence of a deeply incised valley, and the Stenlille-1 core is interpreted to represent the fill of a deep estuarine channel (Hamberg 1994; L.H. Nielsen, L. Hamberg and E.B. Koppelhus in: Nielsen 1995).

\section{Lagoonal facies association}

This association occurs commonly in the Gassum Formation and was cored in the Flyvbjerg-1, Frederikshavn-2, Stenlille-1, -2, -6, Thisted-3, Vedsted-1 and Års-1 wells (Figs 7, 8, 9, 12, 14, 15). It is locally present in the uppermost part of the Fjerritslev Formation on the Skagerrak-Kattegat Platform, where it was cored in the Skagen-2 well. It is relatively uncommon in the Haldager Sand Formation, and was only cored in the Frederikshavn-1 well.

The association consists of muddy and sandy heteroliths and carbonaceous claystones and sandstones, typically forming successions $1.5-11 \mathrm{~m}$ thick, capped by coal seams, carbonaceous claystones and heteroliths with rootlets or a ravinement surface with shoreface sandstones. Good examples are evident in cores from the Gassum Formation at Stenlille (Fig. 14; Hamberg 1994; L.H. Nielsen, L. Hamberg and E.B. Koppelhus in: Nielsen 1995). Estuarine coaly beds are erosionally overlain by wave-rippled, carbonaceous sandstones and heteroliths of mudstone and well-sorted, fine-grained sandstone and siltstone showing parallel to incipient wave-ripple lamination or hummocky cross-stratification. Abundant sand-filled synaeresis cracks occur in the mudstones. The sandstones thin and fine upwards, passing up into a laminated heterolith of mudstone and siltstone. The trace fossils Teichichnus isp. and Planolites isp. occur commonly.

Other examples show laminated and wave-rippled siltstones and heteroliths interbedded with erosionally based cross-bedded sandstones and inclined heterolithic strata (Figs 7A, 9B). Drapes of organic debris and small ripple-foreset laminae occur locally within the foresets. The successions fine upwards from fine- to mediumgrained sandstones to highly carbonaceous heteroliths or muddy siltstones, commonly homogenised by dense rootlets. Siderite-cemented layers, $1-5 \mathrm{~cm}$ thick, commonly occur in the mudstone beds. The inclined het- 

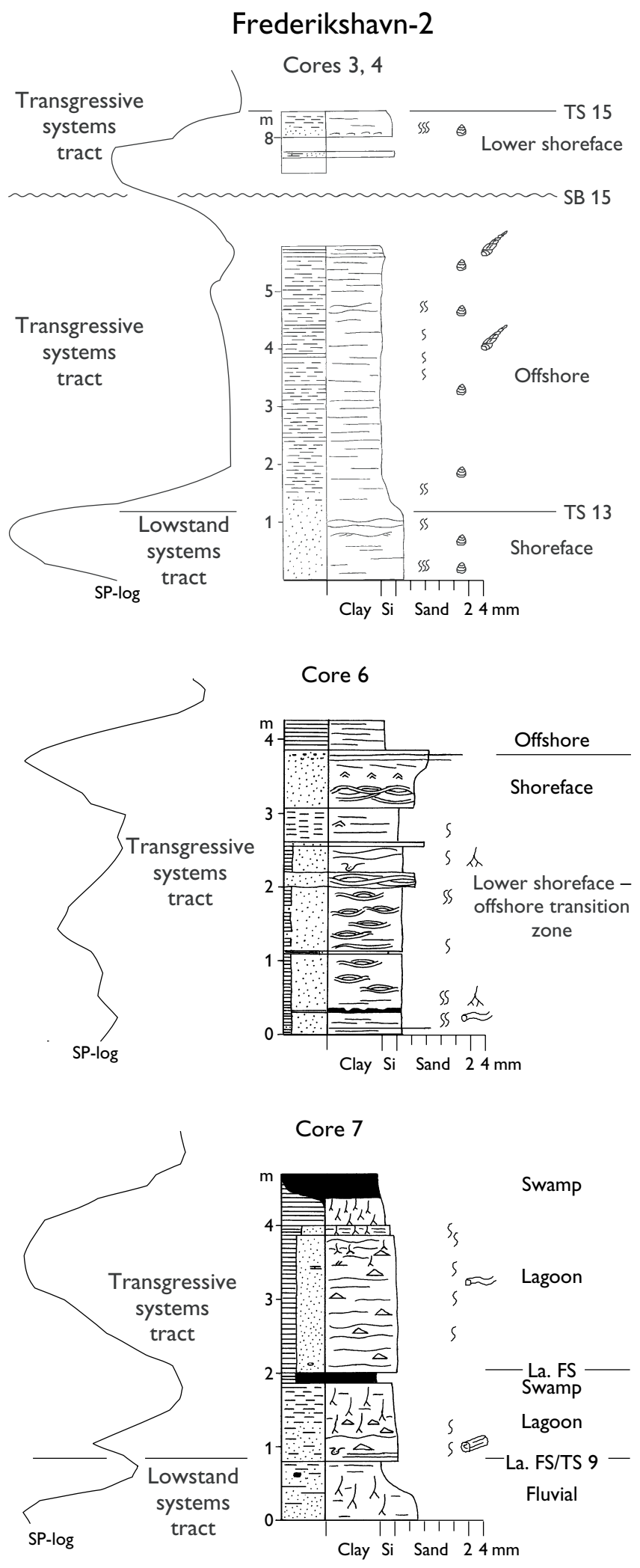

eroliths dip $2-10^{\circ}$ and are composed of thinly and rhythmically interbedded carbonaceous sandstones and mudstones with large fragments of plants and branches. A sapropelitic coal bed, $5 \mathrm{~cm}$ thick, with a very high content of alginite, sporinite and bituminite occurs in the Års-1 core (Fig. 9B; Thomsen 1984).

From the uppermost part of the Fjerritslev Formation as defined by well logs in Skagen-2 (Michelsen 1978), cores with poor recovery show units, $2-4 \mathrm{~m}$ thick of greyish, fine-grained micaceous sandstones and coarse siltstones, dark grey to almost black, carbonaceous and poorly laminated mudstones, and coaly beds. Thick, long rootlets are very common; an upwards change from very small to large rootlets occurs in one unit. Cores with poor recovery from the Haldager Sand Formation in the Frederikshavn-1 well show 10-12 m of almost homogeneous dark claystones with few silt-streaks, muddy and sandy heteroliths with laminated and muddraped cross-laminated sand layers, and a few thin coarse-grained, pebbly layers. Pyrite occurs as large nodules and as cement in sandstones. Plant fragments, large coal fragments or coal seams, possible rootlets and weak bioturbation are also present.

The wave-rippled sandstone at the base of the lagoonal succession in Figure 14 is interpreted as a transgressive lagoonal shoreline deposit, and the overall fining-upwards trend of the wave-reworked sandstones and heteroliths reflects deposition in increasingly deeper lagoonal water. Facies successions capped by coal beds or rooted sediments are interpreted as the fill
Fig. 15. Core logs of the Gassum (core 7, lower core 6) and Fjerritslev Formations (upper core 6, cores 4, 3) in the Frederikshavn-2 well. Core 7 shows fluvial deposits of the LST overlain by lagoonal deposits of the TST, sequence Fj 1 . Core 6 shows sandstones and heteroliths of the shoreface - offshore transition zone (Gassum Fm) and offshore mudstones (Fjerritslev Fm) belonging to the TST of sequence Fj 3. The mudstones have yielded $D$. priscum dinoflagellate cysts (Dybkjær 1991). Core 3 illustrates a thin calcite-cemented sandstone bed that overlies, and is succeeded by, offshore mudstones. Ostracods of the G. apostolescui-K. (K.) foveolata Subzone occur in the transgressive, offshore mudstones of sequence $\mathrm{Fj} 5$ (between TS 13 and SB 15) indicating an Early Pliensbachian age, while ostracods of the upper part of the O. adenticulata $-N$. (N.) simplex Zone occur in the transgressive mudstones of sequence $\mathrm{Fj} 7$ above TS 15 indicating a late Late Pliensbachian age (Michelsen 1975). A hiatus corresponding to at least the Margaritatus Zone is thus indicated at SB 15.

La. FS, lagoonal flooding surface. For legend, see Fig. 5. 
of lagoons that gradually developed into coastal marshes (e.g. Fig. 15, core 7), while successions overlain by shoreface sandstones reflect rising sea level and marine flooding of the coastal area. The fining-upwards units of erosionally-based cross-bedded sandstones overlain by carbonaceous heteroliths or siltstones with rootlets are interpreted as the fills of small channels, and the inclined, stratified heteroliths were formed by point bar deposition (Thomas et al. 1987). Deposition probably took place in tidally influenced creeks that formed part of a tidal drainage network near a vegetated lagoonal margin. A brackish lagoon is similarly indicated by the weakly bioturbated sandstones and mudstones with abundant rootlets and well-preserved plant material in the Flyvbjerg-1 and Vedsted-1 cores (Figs 8, 12). The composition of the coal bed in Års-1 indicates deposition of organic-rich mud in an anoxic brackish to freshwater environment.

The successions cored from the uppermost part of the Fjerritslev Formation and the lowermost part of the Haldager Sand Formation in the Skagen-2 well, and from the middle part of the Haldager Sand Formation in the Frederikshavn-1 well are interpreted as lagoon and swamp deposits by analogy to well-cored examples from contemporaneous deposits on Bornholm (Nielsen 1995). The interpretation is supported by a significant pyrite content in the coal seam from the Fjerritslev Formation (Petersen et al. 2003, this volume). The delicate rootlets may represent small, salt-tolerant pioneer plants or sea-meadows that vegetated muddy lagoonal flats, while the larger rootlets close to the top of the succession may represent larger land plants that became dominant when the lagoon silted up and became a marsh.

\section{Shoreface and foreshore facies association}

This association is very common in the Gassum Formation and has been cored in many wells (Børglum-1, Farsø-1, Flyvbjerg-1, Frederikshavn-2, Gassum-1, Horsens-1, Stenlille, Thisted-3, Ullerslev-1, Vedsted-1 and Års-1 wells; Figs 5-7, 10, 12, 13, 15). The association occurs locally in the Fjerritslev Formation especially from the Sorgenfrei-Tornquist Zone and the Skagerrak-Kattegat Platform.

The facies association consists primarily of hummocky cross-stratified and wave-rippled, light olivegrey to grey, locally weakly glauconitic sandstones and coarse-grained siltstones with coal fragments and scattered pyrite nodules in places (Fig. 11C-K). In the
Gassum Formation, the association is $4-30 \mathrm{~m}$ thick and typically sharply overlies offshore mudstones (L.H. Nielsen, L. Hamberg and E.B. Koppelhus in: Nielsen 1995). Thick sandstone successions are common close to the southern and eastern basin margins, and in the basin centre in the lower part of the Gassum Formation. The sandstones are erosionally based and either show blocky log motifs or comprise several units, $2-5 \mathrm{~m}$ thick, separated by thinner and slightly finer grained sandy beds or, in places, heteroliths. The heteroliths may be intensely burrowed and Teichichnus isp. is present. The Gassum-1 core from a blocky succession shows faint, parallel lamination, low-angle cross-bedding and structureless intervals (Fig. 13A). Wave-ripple crosslamination and trough cross-bedding may be outlined by drapes of organic debris. The sandstones are generally capped by a sharp transgressive surface of marine erosion overlain by offshore mudstones, or locally by a calcite-cemented sandstone with small pebbles and shells or up to $0.5 \mathrm{~m}$ of fining-upwards sandstones and heteroliths (Fig. 11D-F).

In the upper part of the Gassum Formation, the sandstones are thinner and typically form two or three units separated by muddy, burrowed, wave-rippled and wavy bedded heteroliths (Hamberg \& Nielsen 2000). Horizontal burrows, large vertical burrows and Skolithos isp. occur locally in the sandstones. The lower sandstones are typically fine-grained and hummocky crossstratified with a sharp, erosional base mantled by coarser grains, rip-up clasts, sideritic clasts and carbonaceous debris. The upper sandstones are fine- to mediumgrained, commonly with a weak coarsening-upwards tendency, and show swaley cross-stratification, trough and planar cross-bedding, low angle cross-bedding, parallel lamination and wave-ripple lamination. Rootlets are locally preserved (e.g. Stenlille-2; Hamberg \& Nielsen 2000).

Sharp-based shoreface sandstones also occur in the Fjerritslev Formation as shown by cores and well logs in the Stenlille wells (Figs 16, 17). Cuttings samples and well logs from the Sorgenfrei-Tornquist Zone and the Skagerrak-Kattegat Platform indicate a succession of sandstones or siltstones interbedded with marine mudstones. Core pieces from the upper part of the F-II member of the Fjerritslev Formation from the Skagerrak-Kattegat Platform (Frederikshavn-1, -2) show an olive-grey, greenish or weakly yellowish, micaceous and carbonaceous sandstone which is very fine- to finegrained, muddy, occasionally heterolithic, and almost completely burrowed. Weak parallel to wavy lamination and cross-lamination are locally present. Shell frag- 
Box 12

Box 13

Box 14

Box 15

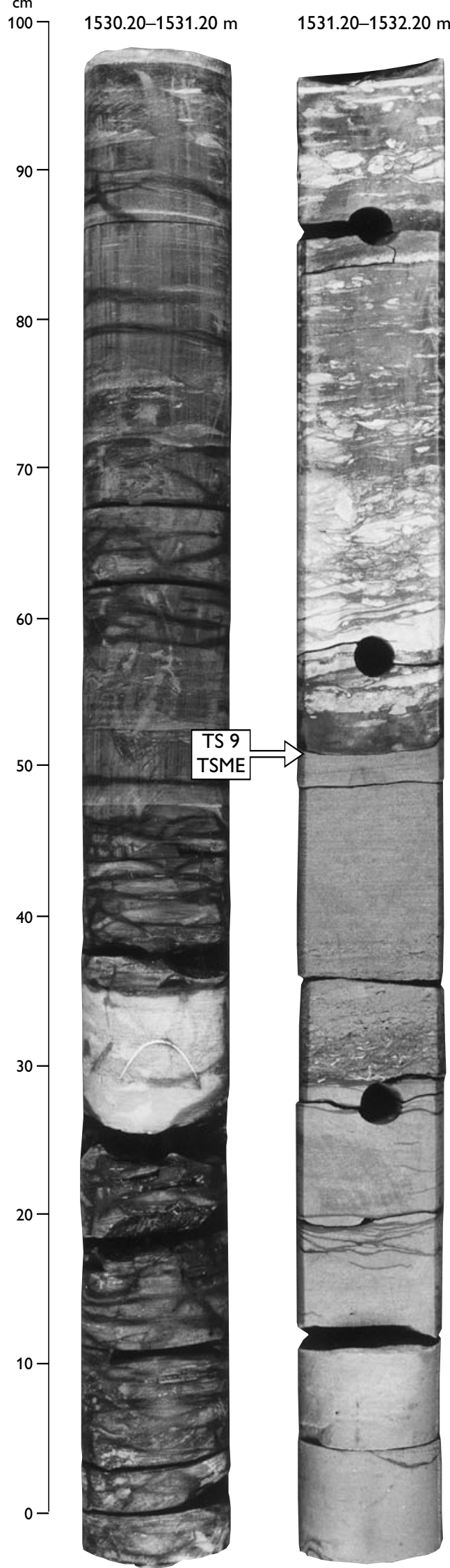

1532.20-1533.20 m

1533.20-1534.20 m

$1534.20-1535.20 \mathrm{~m}$
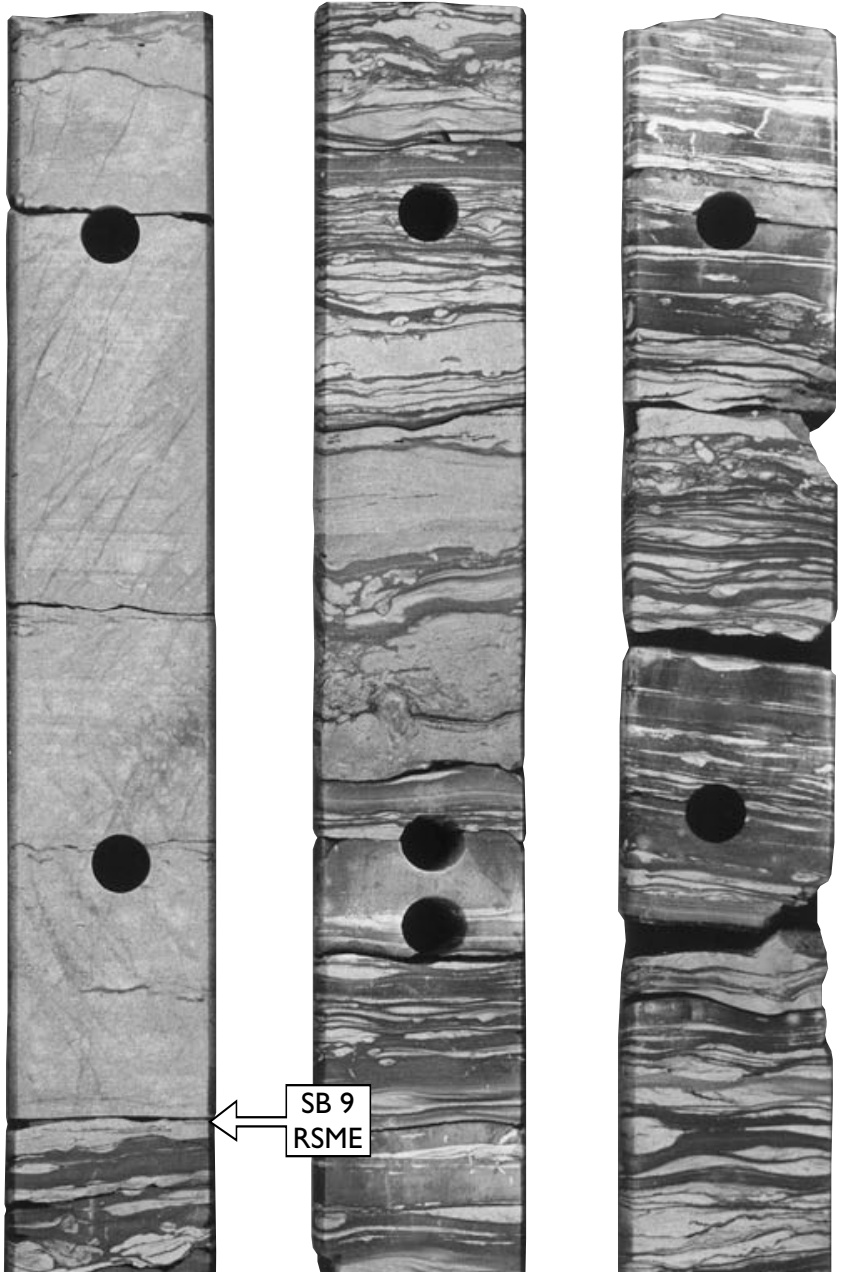

SB 9

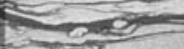

15?

D.
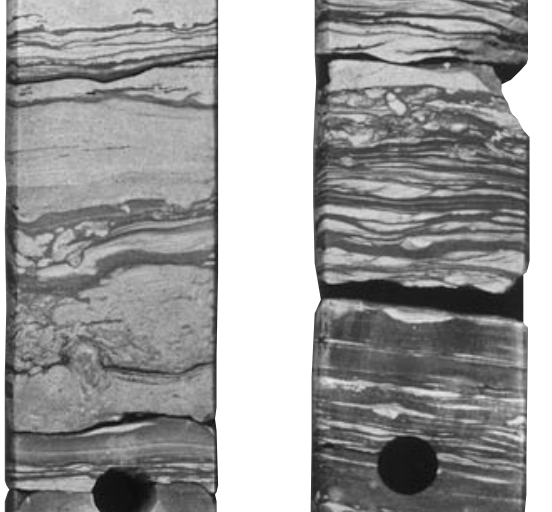

2.

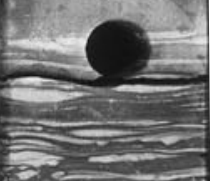

\begin{tabular}{l} 
S 9 \\
\hline SME
\end{tabular}
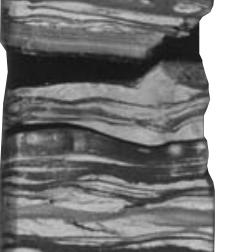

P
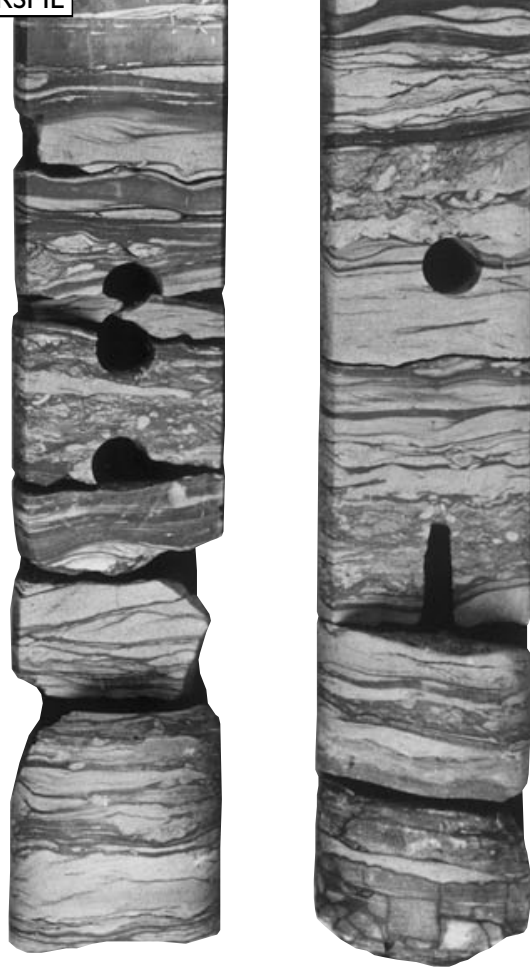


\section{Facing page:}

Fig. 16. Marine lower shoreface to offshore transition zone heteroliths of the HST of sequence Ga 1 (boxes 13 lower part, 14,15 ) erosionally overlain by shoreface sandstones (boxes 12 , 13 upper part) of the LST of sequence Fj 1 bounded below by SB 9, which is developed as a regressive surface of marine erosion (RSME). The LST is sharply topped by TS 9, a transgressive surface of marine erosion (TSME), overlain by transgressive heteroliths and offshore mudstones (boxes 11, 12) of the TST of sequence Fj 1. F-1a member, Stenlille-5, core 3; base lower right, top upper left.

ments occur abundantly and thin siderite- and calcitecemented beds are common. Core pieces from the upper part of the F-IV member (Frederikshavn-1, Skagen-2) show an olive grey, micaceous and carbonaceous, poorly cemented, coarse-grained siltstone grading to very fine-grained sandstone with thin mudstone laminae.

The trace and body fossils, glauconite and pyrite indicate marine conditions. The sharp, basal erosion surface of the sandstones is interpreted as the result of prolonged wave scouring and winnowing in the shoreface during sea-level fall causing bypass and seawards transport of fine-grained material, and formation of a thin lag of coarse sand, small pebbles, claystone chips and plant fragments. The overlying amalgamated hummocky cross-stratified sandstone beds were deposited in the lower shoreface during the waning phase of storms, which eroded away any fair-weather, fine-grained deposits (Dott \& Bourgeois 1982). The interbedded heteroliths are interpreted as having been deposited in the offshore-shoreface transition zone. The trough cross- bedding to swaley cross-stratification and the association of wave-rippled and cross-bedded beds suggest constant reworking by waves and strong currents in the upper shoreface and foreshore (Davidson-Arnott \& Greenwood 1976; Hunter et al. 1979; Leckie \& Walker 1982; Nielsen et al. 1988). The planar cross-beds are interpreted as swash-bars, and the parallel lamination and low-angle cross-bedding represent beach lamination (Thompson 1937; Clifton 1969; Clifton et al. 1971).

The vertical facies successions represent shoreline progradation with minor intermittent transgressions represented by the intercalated heteroliths or fine-grained sandstone beds. Heteroliths are sometimes absent, suggesting that the entire sandstone unit was deposited in the upper shoreface to foreshore (e.g. Gassum-1; Fig. $13 \mathrm{~A})$. With the exception of the scattered rootlet horizons, no evidence of subaerial exposure is seen and the erosion surface at the base of the overlying marine mudstones is interpreted as a ravinement surface.

The sandstones of the F-II and F-IV members of the Fjerritslev Formation were deposited in the offshore-shoreface transition zone as deduced from their fine-grained, muddy and heterolithic nature. The pervasive bioturbation and abundant bivalves in the F-II member indicate a well-oxygenated sea-bottom with infaunal deposit-feeders and suspension-feeders similar to those described from other parts of the Fjerritslev Formation (Pedersen 1986). The lack of shells and burrows in the F-IV sandstones may relate to the generally unfossiliferous nature of the F-IV member, a feature that has been interpreted to reflect anoxia (Michelsen 1975, 1989b).

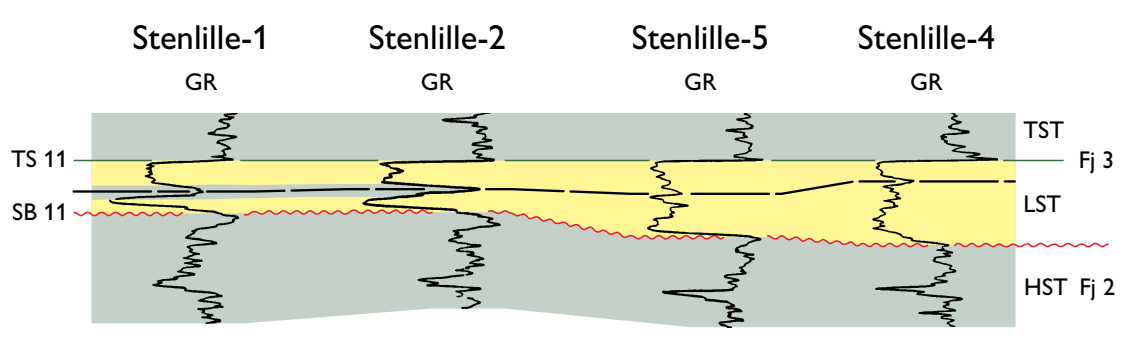

Depositional environment

Offshore mudstone

Shoreface sandstone
Bounding surfaces

$\sim \mathrm{SB} \sim$ Sequence boundary

- TS - Transgressive surface

Correlation line
Fig. 17. Log panel of the Fjerritslev Formation in the Stenlille structure, showing marine shoreface sandstones of the LST of sequence Fj 3, 10-15 m thick, sharply overlying marine offshore mudstones of the HST of Fj 2. SB 11 is developed as a regressive surface of marine erosion. The sandstones are capped by TS 11 , developed as a transgressive surface of marine erosion, overlain by marine mudstones of the TST. The wells are placed in a hypothetical cross-section (c. $1 \mathrm{~km}$ long) perpendicular to the coast with land to the right and sea to the left. The sandstones wedge out seawards and the sandwiched mudstones thicken. 
Recent sandy shoreface profiles commonly show a break in slope from the shoreface sand to offshore mud at water depths of 5-15 m (Everts 1987; Penland et al. 1988; Walker \& Plint 1992; Nummedal et al. 1993); shoreface progradation during a sea-level stillstand would thus produce $5-15 \mathrm{~m}$ of sand. The thick units in the Gassum Formation that show several sandstone beds with finer-grained intercalations are therefore interpreted as amalgamated progradational shoreface sandstones stacked in an aggradational manner, reflecting rising sea level during deposition. Detailed correlation of closely-spaced cored sections in the Stenlille area indicates that the sandstones with sandwiched mudstones and heteroliths are composed of shingles formed during forced regressions punctuated by minor transgressions that caused deposition of the fine-grained deposits (Hamberg \& Nielsen 2000).

\section{Marine offshore facies association}

The association is common in the Gassum Formation where it has been cored in the Fars $\varnothing-1$, Gassum-1, Stenlille, Ullerslev-1 and Års-1 wells (Figs 5, 8-10, 13, 15). It dominates the Fjerritslev Formation and has been cored in many wells (Fig. 16; Michelsen 1975, 1978, 1989a, b; Pedersen 1985, 1986). Cores and log patterns indicate that it occurs in the Haldager Sand Formation from the Sorgenfrei-Tornquist Zone.

The association is dominated by mudstones but also includes siltstones, heterolithic siltstones and very finegrained, heterolithic sandstones. The mudstones are black to dark grey, carbonaceous, with graded or uniform claystone laminae. Scattered silt streaks and lenses are common. Small Planolites isp. and Chondrites isp. burrows are locally present. The mudstones grade into silt-streaked mudstones with dark grey to olive grey, erosionally based, graded siltstone laminae. Incipient ripples are also present; they are 5-10 mm thick, composed of coarse siltstone or very fine-grained sandstone with internal flat cross-lamination, and, in places, loading. Indistinct bioturbation is observed. The heterolithic siltstones consist of black mudstones and olive grey siltstones grading to very fine-grained sandstones. The siltstone laminae are up to $3 \mathrm{~cm}$ thick, graded and have sharp, erosional bases (Fig. 11I, J). Steep-sided scours are observed in places; they are typically $1-4 \mathrm{~cm}$ deep and filled with silt or very fine-grained sand. Wave ripple cross-lamination, with chevrons, offshoots and draping foresets, is common. Burrows are common and the heterolithic siltstones are sometimes completely churned
(Fig. 11K, L). The trace fossils Zoophycos isp., Thalassinoides isp., Teichichnus isp. and Helminthopsis isp. occur sporadically. Very fine-grained, heterolithic sandstones, constructed of sand laminae up to $2 \mathrm{~cm}$ thick and thinner mudstone laminae, show wavy-bedding that is almost obliterated by bioturbation. Well-sorted, coarse-grained siltstones and very fine-grained sandstones show small-scale hummocky cross-stratified sets, 5-15 cm thick, separated by mudstones.

The mudstones typically form relatively uniform successions that may be several tens of metres thick. In places, they form 1-5 $\mathrm{m}$ thick units that become siltier upwards, beginning with black mudstones and terminating with hummocky cross-stratified siltstones, which in turn are abruptly overlain by black mudstones. Coarsening-upwards successions of silt-streaked mudstones overlain by wavy-bedded, heterolithic sandstones also occur (Fig. 5, core 17). The sandstones are capped by a graded, fine-grained sandstone layer containing quartz pebbles up to $0.5 \mathrm{~cm}$ in diameter and overlain by a dark grey-black mudstone, which may be carbonate-cemented. Coarsening-upwards successions, 3-5 $\mathrm{m}$ thick, overlain by fining-upwards successions, 5-15 m thick, have been described from the Fjerritslev Formation (Pedersen 1985).

In the Gassum Formation, the facies association contains dinoflagellate cysts, acritarchs, foraminifers, rare marine bivalves, and fragments of belemnites and ammonites. In the Fjerritslev Formation, it contains a rich fauna of ostracods, bivalves, gastropods, foraminifers, ammonites and other marine fossils in addition to dinoflagellate cysts (Nørvang 1957; Sorgenfrei \& Buch 1964; Michelsen 1975; Pedersen 1986; Dybkjær 1988, 1991; Poulsen 1996). In the Haldager Sand Formation, dinoflagellate cysts, Tasmanites (prasinophycean algae), acritarchs and foraminifers are found (Forbes et al. 1985; Ravn-Sørensen 1989; Poulsen 1992a).

The body and trace fossils and palynomorphs clearly indicate a marine environment. The nature of the mudstones testifies to deposition primarily in calm water from suspension clouds. The graded bedding, scoured surfaces and incipient ripples indicate rapid deposition from the suspension load of storm-generated currents (Pedersen 1985). Isolated coarse silt to fine-grained sand ripples, wave ripples and hummocky cross-stratification reflect an increasing amount of wave reworking during storm events (de Raaf et al. 1977). The scour-fills are interpreted as small gutter-casts reflecting scouring and deposition. The environment was offshore marine below average fair-weather wave base ranging from below storm wave base (the mudstone 
end-member) to the transition zone influenced by storm waves (the hummocky cross-stratified end-member). Pedersen (1986) recognised a normal shale facies fauna in the Hettangian and Lower Sinemurian, and a restricted shale facies fauna in the Upper Sinemurian - Pliensbachian on the basis of fossil content and bivalve ecology in cores from the Gassum-1 well.

The black, carbonaceous and clay-dominated mudstones characterised by the highest gamma-ray values and maximum (leftward) deflection of the SP-log are interpreted to represent the lowest accumulation rate during maximum flooding. The thick, uniform successions in the Fjerritslev Formation are interpreted to reflect relatively rapid vertical aggradation of mud blankets deposited from the suspension loads of storm-generated currents. The more distinctly coarsening-upwards units encased in black mudstones are interpreted as distal parasequences formed by coastal progradation terminated by flooding. The thin, fine-grained pebble layer is interpreted as the distal correlative of a ravinement surface formed during the transgression of the coastal areas, and the carbonate cement probably reflects early diagenesis associated with condensation caused by subsequent flooding. The association corresponds to the 'outer shelf facies association' and the most fine-grained part of the 'inner shelf facies association' described from the Fjerritslev Formation by Pedersen (1985).

\section{Depositional sequences}

The Upper Triassic - Jurassic of the Danish Basin is composed of depositional sequences falling in the time range of the second- to third-order sequences of Mitchum \& Van Wagoner (1991). For convenience, they are here termed third-order sequences without implying correlation to the cycle chart of Haq et al. (1988). Representative well-log cross-sections of the sequences are shown in Figures 19-22, 24 and 25. The third-order sequences are numbered sequentially within each formation, from Vi 1 (Vinding Formation) at the base of the succession to Fr 3 (Frederikshavn Formation) at the top; the uppermost Jurassic to Lower Cretaceous Bø 1, Fr 1, Fr 2 and Fr 3 sequences are not described in detail here. The Vi 1 and Ga 1 third-order sequences are further composed of fourth-order sequences; these are described and shown on Figures 20 and 21 but are not named. Sequence boundaries (SB), maximum flooding surfaces (MFS) and transgressive surfaces (TS) are numbered from 1 (lower) to 23 (upper) irrespective of their hierarchy, although only third-order surfaces are shown on Figure 25.
The facies associations described above form the basis for interpretations of well logs and the subdivision into depositional units. Sequence boundaries, maximum flooding surfaces and transgressive surfaces are identified following Van Wagoner et al. (1990). The sequence stratigraphic interpretation of deposits formed during sea-level fall and the position of the sequence boundary is intensely debated (Plint 1988; Posamentier et al. 1988, 1992; Hunt \& Tucker 1992, 1995; Ainsworth \& Pattison 1994; Helland-Hansen \& Gjelberg 1994; Kolla et al. 1995; Hamberg \& Nielsen 2000; Plint \& Nummedal 2000; Posamentier \& Morris 2000). In this study, the shelf deposits formed during falling sea level are included in the forced regressive systems tract as defined by Hunt \& Tucker (1995). Fluvial incision is interpreted to have occurred during sea-level fall, although deposition may also occur during the fall (Van Wagoner 1995). The fluvial and estuarine valley-fill deposits overlie incised surfaces and are bounded above by regional marine flooding surfaces with marine mudstones. The valley-fills are thus interpreted to have formed during sea-level lowstand and early phases of sea-level rise, and are therefore included in the (late) lowstand systems tract (Van Wagoner et al. 1990), rather than the (early) transgressive systems tract as preferred by others (Allen \& Posamentier 1994).

The dating of the sequences is primarily based on ostracod, dinoflagellate and miospore zones (Fig. 18). The standard ammonite zones are used as chronostratigraphic units (Callomon 1984) and are referred to by the species name alone - the Turneri Zone, for example.

The resolution of seismic data from the Danish Basin is in general too poor to confirm the well-log correlations. The reflectors are relatively parallel except for areas influenced by growth of salt structures, and attributes such as downlap, onlap and offlap are difficult to recognise. It is furthermore difficult to correlate reflectors across major faults and between onshore and offshore surveys. Some regional seismic reflectors may, however, be identified to support the log correlations. The 'top Oddesund Formation' reflector seems to correspond to a significant lower Norian transgressive surface at the base of marine claystones of the Vinding Formation. The 'top Triassic' reflector, which forms a very distinct seismic marker traceable over most of the basin (Baartman \& Christensen 1975; Japsen \& Langtofte 1991), seems to correspond to an upper Rhaetian maximum flooding surface (L.H. Nielsen, L. Hamberg and E.B. Koppelhus in: Nielsen 1995). The seismic marker corresponding to the top of the F-II member is a 


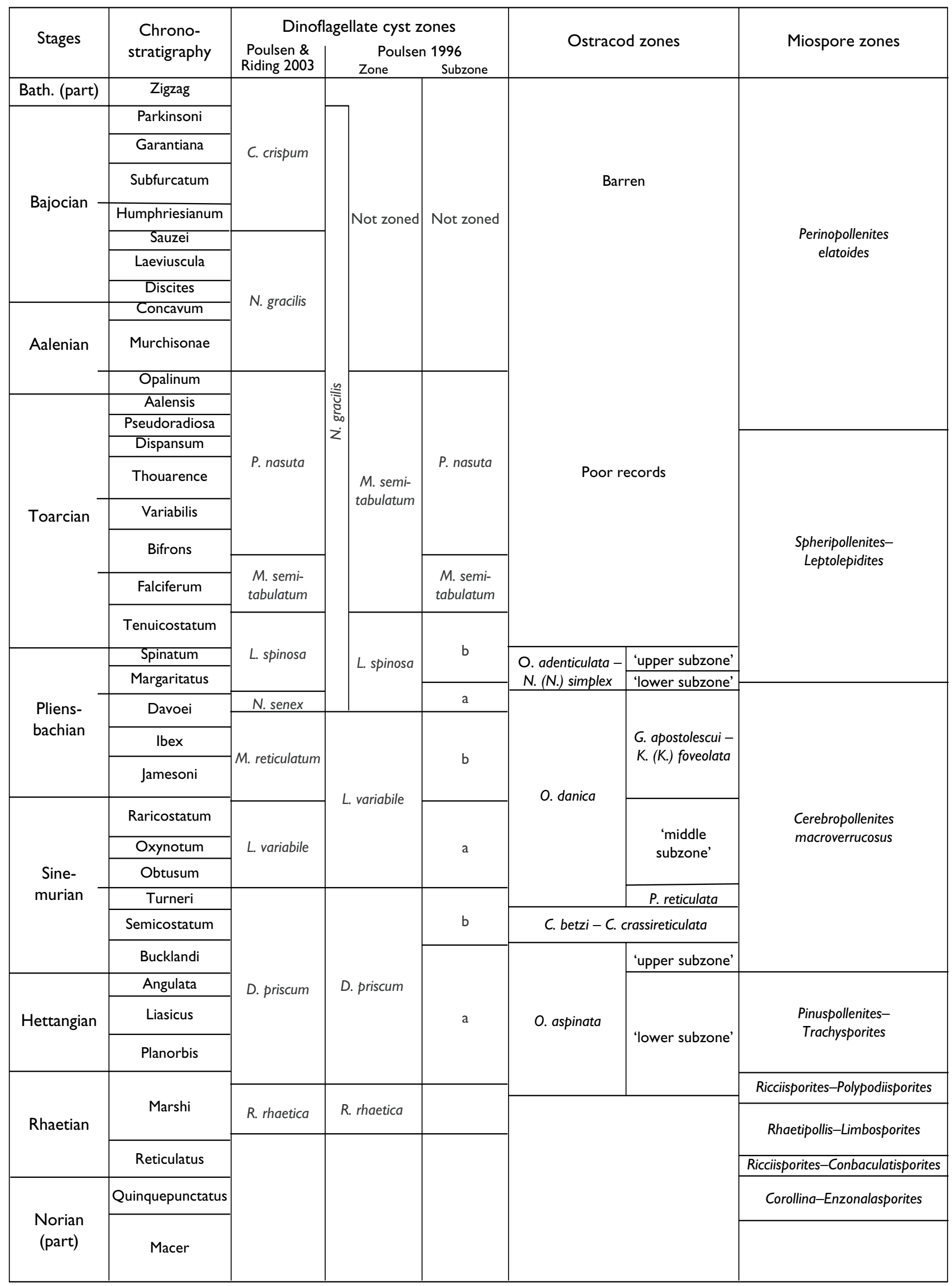


significant Upper Pliensbachian transgressive surface. The 'base Middle Jurassic unconformity' is a deep truncation surface on the Ringkøbing-Fyn High and in the south-western part of the basin caused by uplift (Michelsen 1978; Michelsen \& Andersen 1981; Ziegler 1982; Koch 1983; EUGENO-S Working Group 1988). Less section is missing below the unconformity in the basin centre, and it continues into a seismic conformity in the Sorgenfrei-Tornquist Zone.

\section{Sequence Vi 1 (Lower Norian - lower Rhaetian)}

This sequence comprises the Vinding Formation, the upper part of the Skagerrak Formation and the lower part of the Gassum Formation. It spans the Upper Norian and Rhaetian miospore assemblage Zones I-III of Bertelsen (1978; Zone 1 was dated to the Rhaetian by Bertelsen, but is of late Norian age according to Pedersen \& Lund 1980). Furthermore, miospore zones ranging from the Corollina-Enzonalasporites Zone to the lower part of the Rhaetipollis-Limbosporites Zone and the dinoflagellate Rhaetogonyaulax rhaetica Zone have been identified in some wells (Fig. 18; L.H. Nielsen, L. Hamberg and E.B. Koppelhus in: Nielsen 1995). These data indicate an early Norian - early Rhaetian age. This is supported by the presence of the foraminifer Ammodiscus sp., the ostracod Emphazia sp. and the bivalve Rhaetavicula contorta (Fazekas 1948; Fredbold 1948; Nørvang 1948; Sorgenfrei \& Buch 1964; Christensen 1972).

\section{Base of sequence and transgressive systems tract}

The western, central and southern parts of the Danish Basin were flooded during the early Norian, and continental-sabkha deposits of the Oddesund Formation were overlain by restricted and shallow marine deposits

\section{Facing page:}

Fig. 18. Biozonation of the Danish Basin and the Fennoscandian Border Zone based on data from Michelsen (1975, 1989a), Dybkjær (1988, 1991), Poulsen (1992a, 1996), L.H. Nielsen, L. Hamberg and E.B. Koppelhus (in: Nielsen 1995), Koppelhus \& Batten (1996) and Poulsen \& Riding (2003, this volume) of the Vinding Formation (Christensen 1972; Bertelsen 1978, 1980). The boundary between the two formations is interpreted as a transgressive surface TS 1, and is tentatively adopted as the base of the Vi 1 sequence (Fig. 19, facing page 498). The transgression culminated in the late Norian (Bertelsen 1978), as marked by the maximum flooding surface MFS 1 that is readily recognised in the Vinding Formation on SP and gamma-ray logs from most wells. The MFS 1 is characterised by an olive-grey, very finely laminated claystone in cores (e.g. Ullerslev-1). MFS 1 is tentatively traced into thick lacustrine claystones occurring in the upper part of the Skagerrak Formation along the north-eastern and eastern basin margins and in the western part of the basin (F-1, Inez-1, K-1; Fig. 1). The lacustrine claystones are assumed to be contemporaneous with the marine claystones in the Vinding Formation based on biostratigraphic evidence (Bertelsen 1980); the sporadic occurrence of acritarchs (Bertelsen 1978) suggests that the lakes were slightly brackish and probably formed as a result of the general rise in base-level caused by rising sea level. The transgressive systems tract from TS 1 to MFS 1 consists of fossiliferous limestones, oolites and marine claystones, up to $60 \mathrm{~m}$ thick in the basinal areas. South of the Ringkøbing-Fyn High, in the North German Basin, the Vinding Formation is similarly developed indicating that the high was submerged at this time, precluding the supply of coarse sediment.

\section{Highstand systems tract}

The highstand systems tract bracketed by the thirdorder surfaces MFS 1 and SB 5, consists of a weakly coarsening-upwards succession of marine mudstones, 10-15 m thick, overlain by alternating marine mudstones, shoreface sandstones and estuarine deposits amounting to a total thickness of the HST of up to $125 \mathrm{~m}$ (Fig. 19). The shoreface sandstones are typically sharp-based and occur together with the estuarine deposits at three distinct levels separated by marine mudstones. The three successive shoreface sandstones show a stepwise more basinwards distribution, and define three forestepping fourth-order sequences bounded by SB 2, 3 and 4 (L.H. Nielsen, L. Hamberg and E.B. Koppelhus in: Nielsen 1995; Hamberg \& Nielsen 2000). The sandstones overlie wave-scoured surfaces and were mainly deposited during falling sea level and constitute widespread, forced regressive systems tracts. A cored example is shown in Figure 13A from Gassum-1. In some places, the shoreface sandstones are 
up to $30 \mathrm{~m}$ thick and show a subtle forestepping to aggrading pattern overlain by an aggrading to backstepping pattern reflecting weak overall shoreface progradation during late highstand to falling sea level (highstand to forced regressive systems tract) followed by overall shoreline retreat during the subsequent rise (lowstand to early transgressive systems tract; L.H. Nielsen, L. Hamberg and E.B. Koppelhus in: Nielsen 1995). The shoreface sandstones were incised in places due to further sea-level fall; during subsequent sealevel rise, estuarine sediments were deposited in the incised valleys.

The Vi 1 sequence seems to be absent on the Skagerrak-Kattegat Platform. In the Fjerritslev Trough, which is down-faulted relative to the platform, the sequence consists of alternating units of pebbly fluvial sandstones and lacustrine clays of the upper Skagerrak Formation and lower Gassum Formation (Fig. 19).

\section{Sequence Ga 1 (Lower Rhaetian - Lower Hettangian)}

This sequence is primarily composed of the upper part of the Gassum Formation. The sequence also includes the lowermost part of the Fjerritslev Formation in the basin centre, and 10-20 m of greyish claystones of the uppermost Skagerrak Formation on the SkagerrakKattegat Platform which probably belong to the miospore Rhaetipollis-Limbosporites Zone (E.B. Koppelhus, personal communication 1994). With reference to the dinoflagellates, the sequence spans the upper part of the Rhaetogonyaulax rhaetica Zone and the lowermost part of Dapcodinium priscum Zone; according to the spores and pollen, it spans the upper part of the Rhaetipollis-Limbosporites Zone, the RicciisporitesPolypodiisporites Zone and the lowermost part of the Pinuspollenites-Trachysporites Zone.

\section{Base of sequence and lowstand to transgressive systems tract}

The lower boundary of the third-order sequence is defined by a basinwide, lower Rhaetian fluvial incision surface, SB 5, present in the lower Gassum Formation (Fig. 19). The third-order SB 5 marks the largest basinwards shift in facies and the most pronounced fluvial incision in the upper Norian - Rhaetian succession, and an extensive late Rhaetian coastal onlap onto the surface occurs towards the north-east (L.H. Nielsen, L.
Hamberg and E.B. Koppelhus in: Nielsen 1995). The sequence boundary cuts into marine offshore mudstones and shoreface sandstones of the lower Gassum Formation. In the deep central part of the basin, the sequence boundary occurs at the base of shoreface sandstones (e.g. Voldum-1) or at the base of estuarine sandstones (e.g Gassum-1; Fig. 13B). Close to the southwestern basin margin, along the Ringkøbing-Fyn High (Horsens-1, Ullerslev-1, Vemb-1) and the north-eastern margin at the Børglum Fault (Flyvbjerg-1), the sequence boundary is overlain by fluvial sandstones belonging to the lowstand systems tract. In the Himmerland Graben (Farsø-1, Års-1), the Sorgenfrei-Tornquist Zone (Terne-1), at Stenlille (Stenlille-13) and at Thisted (Thisted-1, -3, -4), the sequence boundary shows deep incision and it is overlain by fluvial-estuarine deposits up to $45 \mathrm{~m}$ thick, showing a variable development. Cores from the incised valley-fills show fluvial-estuarine and lagoonal sandstones and mudstones (Figs 7A, $\mathrm{B}, 8,9 \mathrm{~A}, 14)$. The valley-fills commonly have a basal unit of fluvially dominated sandstones, a middle unit of lagoonal mudstones and an upper unit of shoreface sandstones reflecting vertical stacking of an estuarine valley system caused by progressive drowning (Allen \& Posamentier 1994; Dalrymple et al. 1994). In the Stenlille area, the thick incised valley-fill is capped by a heterolithic sandstone with roots overlain by transgressive lagoonal deposits (Fig. 14). In some wells, the sequence boundary occurs on top of shoreface sandstones belonging to the underlying forced regressive systems tract (e.g. Rønde-1, Voldum-1) and it coincides with a transgressive surface of marine erosion indicating very limited fluvial incision.

The transgressive systems tract overlying the transgressive surface TS 5 typically consists of $20-40 \mathrm{~m}$ of offshore mudstones and shoreface sandstones. The systems tract is relatively uniformly developed over large parts of the basin and shows an overall backstepping pattern that culminates with a widespread marine claystone containing the third-order MFS 7. Two widely distributed shoreface sandstones occur within the transgressive systems tract; they both overlie a sharp, wavescoured base and are erosionally overlain by transgressive marine mudstones. In places, cores show roots preserved in shoreface sandstones below the ravinement surface indicating subaerial exposure during the lowest sea-level stand (Hamberg \& Nielsen 2000). The sandstones are interpreted as forced regressive systems tracts reflecting two fourth-order sea-level falls superimposed on the general third-order rise that culminated at MFS 7 (SB 6, SB 7; Fig. 19). The sandstones show a back- 
stepping pattern and testify to a progressive, stepwise landwards shift of the lowstand shorelines.

\section{Maximum flooding surface, MFS 7 and highstand systems tract}

The condensed section containing the MFS 7 is easily recognised on well logs, and is traced throughout the basin from the easternmost part (Hans-1, Lavø-1) to the westernmost (F-1, Inez-1, K-1), from the SkagerrakKattegat Platform (Frederikshavn-2, Sæby-1) to well sections south of the Ringkøbing-Fyn High (e.g. Rødby-1), indicating that the entire basin including the platform was flooded. In cores from the Gassum-1 well, the ammonite Curviceras sp. (determined by G. Bloos, S. Elmi, S. Franiatte and R. Mouterde in: Poulsen 1996), indicating the Johnstoni Subzone (the upper subzone of the Lower Jurassic Planorbis Zone), occurs c. $30 \mathrm{~m}$ above MFS 7 (Fig. 13C). In Rødby-1, where MFS 7 occurs in marine claystones and heteroliths marked by a distinct rightwards deflection of the SP-log, the Triassic- Jurassic boundary as determined by the spore-pollen Ricciisporites-Polypodiisporites and Pinuspollenites-Trachysporites Zones occurs $4.3 \mathrm{~m}$ above MFS 7, and Lower Jurassic ammonites (Psiloceras planorbis, determined by J.H. Callomon and D.T. Donovan in: Poulsen 1996) and the base of the ostracod Ogmoconchella aspinata Zone are found $13 \mathrm{~m}$ and $2.4 \mathrm{~m}$ above MFS 7 , respectively (Bertelsen \& Michelsen 1970; Michelsen 1973, 1975; Lund 1977; Poulsen 1992a, 1996). The lowermost Hettangian ostracods and the Rhaetian-Hettangian boundary based on spores and pollen occur just above MFS 7 in several wells, and the boundary between the Rhaetian $R$. rhaetica and the uppermost Rhaetian lowermost Sinemurian D. priscum Zones (dinoflagellates) seems to coincide with MFS 7 (Michelsen 1975; L.H. Nielsen, L. Hamberg and E.B. Koppelhus in: Nielsen 1995; Poulsen 1996). MFS 7 is thus well dated to the latest Rhaetian and represents the maximum extent of the sea in Rhaetian time.

MFS 7 is overlain by an overall forestepping succession of marine mudstones and sandstones constituting a highstand systems tract, up to $35 \mathrm{~m}$ thick. Cores from the Stenlille area show offshore silt-streaked mudstones that coarsen upwards to lower shoreface heterolithic siltstones and sandstones. A higher-order sequence is recognised within the third-order highstand systems tract based on a widespread, thin shoreface sandstone that passes into fluvial sandstones overlying SB 8 in the north-eastern part of the basin (Fig. 19).

\section{Sequence Fj 1 (Lower-Middle Hettangian)}

Sequence $\mathrm{Fj} 1$ consists of marine heteroliths of the uppermost Gassum Formation and marine mudstones of the F-Ia unit (Fjerritslev Formation) in the southwestern and central parts of the basin (Fig. 20, following page 498). Towards the east, north-east and north, sandstone-dominated strata of the Gassum Formation gradually take over. On the Skagerrak- Kattegat Platform and in Terne-1 and Hans-1 in the Sorgenfrei-Tornquist Zone, the sequence consists exclusively of the Gassum Formation. The sequence spans the lower part of the O. aspinata Zone of Michelsen (1975, 1989a), and the lower parts of the D. priscum and PinuspollenitesTrachysporites Zones of Dybkjær (1991) and Poulsen (1992a, 1996).

Base of sequence, SB 9 and lowstand systems tract

SB 9 is marked by a regional change from forestepping to backstepping sedimentary packages (Fig. 20). In the Stenlille area, SB 9 is marked by shoreface sandstones overlying heteroliths (Fig. 16). On the Thisted salt dome, fluvial sandstones cut down into marine mudstones and sandstones of the Gassum Formation. Deep incision is also indicated by SB 9 in the Himmerland Graben, where cores and logs show a thick valley-fill of estuarine sandstones overlain by lagoonal siltstones and mudstones with abundant rootlets and a thin coal seam in Års-1 (Fig. 9B) and fluvial-estuarine sandstones in Hyllebjerg-1 (Fig. 20). Farther to the north-east, SB 9 is traced into shoreface sandstones (Vedsted-1) and to the base of fluvial sandstones, 2-10 m thick overlying marine mudstones and sandstones (Flyvbjerg-1, Frederikshavn-1, -2, -3). Sandstones most likely of fluvial origin were cored in Børglum-1 (Fig. 5). The lowstand systems tract thus consists of fluvial, estuarine and shoreface sandstones passing basinwards into offshore heteroliths and mudstones.

In most of the basin, SB 9 occurs within lowermost Hettangian strata. Towards the basin margins, it is correlated with the widespread base Hettangian unconformity present on Bornholm, in Skåne, Poland and Germany (Troedsson 1948; Gry 1969; Dadlez 1976; Lund 1977; Guy-Ohlson 1981; Gravesen et al. 1982; Sivhed 1984; Hallam 1988, 1992; Bloos 1990; Pieńkowski 1991; Norling et al. 1993; Ahlberg \& Arndorf 1994; Surlyk et al. 1995). SB 9 thus records the greatest regional basinwards shift in facies of the upper Rhaetian - lowermost Hettangian, accompanied by fluvial incision and shoreface erosion. 


\section{Transgressive systems tract}

The lowstand deposits are capped by TS 9 overlain by backstepping to aggrading, offshore heteroliths and mudstones, 3-25 m thick (Figs 19, 20). Cores from Stenlille-5 show lowstand shoreface sandstones overlain by mudstones resting on a transgressive surface of marine erosion (Fig. 16). In the southern part of the basin, TS 9 is marked by a change from marine heteroliths and silty mudstones to more uniform mudstones. In most of the basin, TS 9 coincides with the lithostratigraphic boundary between the Gassum and Fjerritslev Formations. Towards the north-east, TS 9 occurs within the Gassum Formation, and the transgressive systems tract consists of marine mudstones and 3-4 m of shoreface sandstones (e.g. Flyvbjerg-1, Vedsted-1; Figs 19, 20). Closer to the basin margin, the transgressive systems tract consists of aggrading coastal plain deposits with coal beds (e.g. Hans-1; Fig. 1). In the Frederikshavn and Skagen wells, c. $20 \mathrm{~m}$ of stacked lagoonal parasequences, indicated by serrated log-pattern and cores containing a mixed brackish palynomorph assemblage (Dybkjær 1991, tables 3, 4), are overlain by offshore mudstones (Fig. 15). In the Gassum-1 well, the Johnstoni Subzone is indicated $14-15 \mathrm{~m}$ above TS 9 by the occurrence of Curviceras sp. (Fig. 13C; Poulsen 1996), indicating together with the identified palynomorphs that TS 9 occurs in the lowermost Hettangian.

\section{MFS 9 and highstand systems tract}

The maximum flooding surface MFS 9 is overlain by c. 25-75 m of marine mudstones primarily showing an aggrading pattern in the southern and central parts of the basin. The mudstones have a low content of ostracods, foraminifera and infaunal deposit-feeding bivalves and a high content of land-derived organic matter (Michelsen 1975, Pedersen 1986; Dybkjær 1991). Cores show poorly laminated to homogeneous, dark grey mudstones with scattered siltstone lenses and shell debris. Farther to the north-east is a $60-75 \mathrm{~m}$ thick succession of aggrading shoreface and fluvial-estuarine sandstones interbedded with thin marine sandstones and mudstones (Børglum-1, Flyvbjerg-1; Figs 5, 12). The mudstones sometimes contain a rich, but low-diversity ostracod fauna (Fig. 12, core 7; Michelsen 1975). Biostratigraphic evidence suggests that MFS 9 belongs to the lower mid-Hettangian, being located above the lowermost Hettangian SB 9 and below the upper Hettangian log marker a of Michelsen (1989b).

\section{Sequence Fj 2 (Upper Hettangian - lowermost Sinemurian)}

Sequence $\mathrm{Fj} 2$ consists of marine mudstones and heteroliths of the upper F-Ia unit (Fjerritslev Formation) in most of the basin (Fig. 21, following page 498). Along the north-eastern and eastern margins of the SorgenfreiTornquist Zone, the sequence consists of sandstones of the Gassum Formation. It spans the upper part of the O. aspinata Zone (ostracods) of Michelsen (1975, 1989a), part of the D. priscum Zone (dinoflagellates), the upper part of the Pinuspollenites-Trachysporites Zone and the lowermost part of the Cerebropollenites macroverrucosus Zone (spore-pollen) of Dybkjær (1991) and Poulsen (1992a; Fig. 18). The sequence appears to be absent locally on the Skagerrak-Kattegat Platform due to erosional truncation (Fig. 20).

\section{Base of sequence and lowstand systems tract}

The base of the sequence, SB 10, is defined by marine shoreface sandstones, heteroliths or sandy mudstones constituting the lowstand systems tract sharply overlying uniform to weakly forestepping marine mudstones in the Fjerritslev Trough, Himmerland Graben and at Stenlille (Fig. 21). Farther into the basin, SB 10 appears to be conformable and is marked by a subtle change to more silty mudstones forming a thin lowstand systems tract. Towards the north-eastern margin of the Fjerritslev Trough, SB 10 is tentatively traced into aggrading marine and fluvial sandstones along the Børglum Fault (Børglum-1, Flyvbjerg-1; Fig. 20). SB 10 probably belongs to the upper Hettangian Angulata Zone as it is located between log markers $\mathrm{a}$ and $\mathrm{b}$ of Michelsen (1989b; Fig. 21). The lowstand systems tract is capped by TS 10 .

Transgressive systems tract, MFS 10, highstand and forced regressive systems tracts

The transgressive systems tract overlying TS 10 consists of 10-20 m of aggrading to slightly backstepping marine mudstones in most of the basin passing into backstepping marine shoreface and offshore sandstones and heteroliths, 20-30 m thick close to the Børglum Fault. In the basinal mudstone-dominated successions, TS 10 corresponds to log marker b of Michelsen (1989b; Fig. 21). The maximum flooding surface is well-defined in the Fjerritslev Trough and Himmerland Graben, where it 
is overlain by distinctly forestepping offshore mudstones that form a c. 8-15 m thick highstand systems tract. Distally in the basin, MFS 10 is positioned within relatively homogeneous mudstones. The highstand deposits in the Fjerritslev Trough are sharply overlain by weakly forestepping to aggrading shoreface sandstones, c. 5-20 m thick that are interpreted as a forced regressive systems tract that wedges out towards the deeper parts of the basin (Figs 8, 12, 20).

MFS 10 is located below the F-Ia/F-Ib boundary in the Lower Sinemurian Bucklandi Zone and above log marker b which was suggested to occur at the Hettangian-Sinemurian boundary by Michelsen (1989b). However, in Stenlille-2, MFS 10 seems to be located in the Hettangian Pinuspollenites-Trachysporites Zone (spore-pollen; Dybkjær 1991). In Sæby-1, it occurs at the top of the Hettangian defined by miospores (Church et al. 1986; Michelsen \& Nielsen 1991). A latest Hettangian to earliest Sinemurian age, most likely the Angulata Zone, is thus suggested for MFS 10.

\section{Sequence Fj 3 (Lower-Upper Sinemurian)}

Sequence $\mathrm{Fj} 3$ consists of the topmost part of the F-Ia unit and the lower F-Ib unit in most of the basin. In the Sorgenfrei-Tornquist Zone and on the Skagerrak-Kattegat Platform, the sequence includes the uppermost part of the Gassum Formation and the F-I member (Frederikshavn wells; Fig. 20; Nielsen \& Japsen 1991). Based on ostracods, the sequence spans the uppermost part of the O. aspinata Zone, the Cristacythere betziCristacythere crassireticulata Zone, and the lower part of the Ogmoconchella danica Zone, including the Progonoidea reticulata Subzone of Michelsen (1975, 1989b). It spans the upper part of the D. priscum and the lower part of the Liasidium variabile Zones (dinoflagellates), and the C. macroverrucosus Zone (sporepollen) of Dybkjær (1988, 1991) and Poulsen (1992a, 1996).

\section{Base of sequence, lowstand systems tract and TS 11}

The base of the sequence (SB 11) is defined by small but distinct log changes indicating a relatively abrupt change from uniform mudstones to heterolithic mudstones in most of the basin, and to coarser heteroliths in the Himmerland Graben (Figs 20, 21). The change is interpreted to reflect shallowing and defines the conformable SB 11 overlain by lowstand heteroliths. SB 11 occurs in the upper part of the O. aspinata Zone above log marker b of Michelsen (1989b) and just below the top of the F-Ia unit, suggesting that it occurs in the Bucklandi Zone. In the Stenlille area, the lowstand systems tract is $10-15 \mathrm{~m}$ thick with shoreface sandstones sharply overlying marine mudstones (Fig. 17).

From the basin, SB 11 is traced into dominantly aggrading parasequences of marine shoreface sandstones and thin mudstones in the Vedsted- 1 well in the Fjerritslev Trough (Fig. 20). The aggrading parasequences constituting the lowstand systems tract are capped by a transgressive surface TS 11 overlain by two backstepping shoreface parasequences. SB 11 and TS 11 are traced further to Flyvbjerg-1 and Børglum-1, where the surfaces tend to amalgamate on top of a $12-20 \mathrm{~m}$ thick unit of marine shoreface sandstones, interpreted as the highstand or forced regressive systems tract of the underlying sequence. The logs from the three closely spaced Frederikshavn wells indicate 4-24 $\mathrm{m}$ of fluvial sandstones overlying SB 11 that shows variable depths of incision. The fluvial sandstones belong to the lowstand systems tract and are overlain by marine transgressive sandstones that yield $D$. priscum dinoflagellate cysts (Figs 15, 20; Dybkjær 1991). TS 11 is thus no younger than the Bucklandi Zone, as D. priscum cysts disappear or occur only very sporadically above this zone (Woollam \& Riding 1983; Poulsen \& Riding 2003, this volume). TS 11 is traced further to Skagen-2, where cores with poor recovery show a few metres of siltstones with the marine bivalve Oxytoma sinemuriensis indicating the Bucklandi to Semicostatum Zones above TS 11 (Sorgenfrei \& Buch 1964). Core samples indicate that the transition from the Hettangian PinuspollenitesTrachysporites Zone to the Sinemurian C. macroverrucosus Zone (Poulsen 1992a) occurs very close to TS 11, which coincides with the boundary of the Gassum and Fjerritslev Formations. Farther to the south, in the Sorgenfrei-Tornquist Zone, TS 11 also coincides with the boundary between the Gassum and Fjerritslev Formations (Terne-1 and Hans-1) which occurs just above the Hettangian-Sinemurian boundary (Michelsen \& Nielsen 1991). In the Øresund-8 and -9 wells, sandy paralic deposits without ostracods are overlain by transgressive marine mudstones with ostracods of the C. betzi-C.crassireticulata Zone corresponding to the Semicostatum Zone (Michelsen 1975).

In the basinal successions of continuous mudstones, TS 11 coincides with the top of the F-Ia unit, where subtle log changes indicate a shift from lowstand heterolithic mudstones to transgressive homogeneous mudstones (Fig. 21). TS 11 typically occurs $10-20 \mathrm{~m}$ 
below log marker c, which Michelsen (1989b) refers to the boundary between the Bucklandi and Semicostatum Zones. Hence, based on the ostracod and palynomorph data, the significant flooding represented by TS 11 occurred in the latter part of the Bucklandi Zone and appears to be of the same age in the entire basin. The flooding caused a significant decrease in diversity and density of the ostracod and bivalve faunas with a marked low in the Semicostatum Zone (Pedersen 1986; Michelsen 1989b). Lithostratigraphically, the transgressive surface corresponds to the F-Ia/F-Ib boundary in most of the basin and to the Gassum/Fjerritslev Formation boundary in the Sorgenfrei-Tornquist Zone and on the Skagerrak-Kattegat Platform. This indicates a slightly older age for the formation boundary than that suggested by Michelsen $(1975,1978)$, who based the younger age on a few ostracod fragments from cuttings and poor core samples from Børglum-1, Flyvbjerg-1 and Frederikshavn-2 that were possibly contaminated by drilling mud (O. Michelsen, personal communication 1994).

Transgressive systems tract, MFS 11 and highstand systems tract

In the central parts of the basin, the transgressive systems tract consists of a succession of very homogenous marine mudstones, up to $150 \mathrm{~m}$ thick, showing a subtle backstepping pattern overlain by weakly forestepping mudstones of the highstand systems tract (Figs 20, 21). MFS 11 occurs between the log markers $d$ and e, which are referred to the Turneri and Obtusum Zones, respectively (Michelsen 1989b). A very pronounced thinning of both systems tracts is indicated towards the north-east, where they thin to $c .25 \mathrm{~m}$ in Børglum- 1 and to $10-15 \mathrm{~m}$ in the Frederikshavn wells; in Skagen-2, they form an amalgamated succession of siltstones, less than $10 \mathrm{~m}$ thick. This dramatic thinning of the sequence is supported by biostratigraphic evidence indicating that the Sinemurian is very thin in the Børglum- 1 , Frederikshavn-2, Skagen-2 and Sæby-1 wells (Michelsen 1975; Dybkjær 1991; Michelsen \& Nielsen 1991; Poulsen 1992a). Much of the thinning seems to be primary, as deep erosion below SB 12 cannot be demonstrated.

\section{Sequence Fj 4 (Upper Sinemurian - Lower Pliensbachian)}

Sequence $\mathrm{Fj} 4$ consists of marine mudstones of the F-Ib unit in most of the basin and includes the lower part of the F-II member on the Skagerrak-Kattegat Platform (Figs 20,21). It spans part of the O. danica and $G$. apostolescui - K. (K.) foveolata Zones (ostracods) of Michelsen (1975, 1989b), and parts of the L. variabile Zone (dinoflagellates) and the C. macroverrucosus Zone (spore-pollen) of Dybkjær (1991) and Poulsen (1996).

Base of sequence, lowstand and transgressive systems tracts, and MFS 12

The base of the sequence, SB 12, is marked by subtle log changes, indicating that homogeneous mudstones are conformably overlain by slightly coarser mudstones over much of the basin including the Sorgenfrei-Tornquist Zone (Figs 20, 21). SB 12 is more clearly marked towards the north-east, where it is overlain by heterolithic sandstones (Børglum-1, Sæby-1 and Frederikshavn wells). SB 12 coincides with log marker g, referred to the Oxynotum Zone by Michelsen (1989b).

In the basinal parts, the lowstand deposits consist of marine mudstones, less than $5 \mathrm{~m}$ thick, that coarsen to siltstones and bioturbated, heterolithic lower shoreface sandstones towards the north-east (Børglum-1 and Frederikshavn wells; Fig. 5). The lowstand systems tract is overlain by uniform, aggrading to weakly backstepping marine mudstones capped by MFS 12 (Fig. 20). MFS 12 coincides with log marker h (Fig. 21) dated to the Raricostatum Zone and corresponds to a very marked low in the density and diversity of ostracods and bivalves in cores from Gassum-1 (Pedersen 1986; Michelsen 1989b). A restricted shale facies without infaunal suspension feeders dominates at this level in the Gassum cores (Pedersen 1986). MFS 12 can be traced to most well sections including wells on the Skagerrak-Kattegat Platform.

\section{Highstand systems tract}

The highstand systems tract is $50-70 \mathrm{~m}$ thick in the Sæby-1 and Frederikshavn wells, and shows an aggrading to forestepping pattern (Fig. 20). Although recovery was poor, the cores from Frederikshavn- 1 and -2 exhibit silty and sandy, bioturbated mudstones with shell debris, that coarsen upwards to muddy, bioturbated, fine-grained sandstones also with shell debris, interpreted as the deposits of the offshore - lower shoreface transition zone. The well logs supported by cores indicate that the upper $15 \mathrm{~m}$ of the highstand systems tract consist of prograding lower shoreface sandstones 
(Fig. 22, following page 498). The lower part of the Lower Pliensbachian G. apostolescui - K. (K.) foveolata Subzone of Michelsen (1975) is indicated in core 5 just above MFS 12 in Frederikshavn-2. The same zone occurs in Skagen-2 in the upper $3 \mathrm{~m}$ of the highstand systems tract, which consists of 5-10 m of intensely burrowed muddy siltstones and fine-grained, lower shoreface sandstones with abundant bivalve fragments. Thus, the highstand deposits belong to the lower Lower Pliensbachian. The palynomorph assemblage resembles that of the contemporaneous shoreface sandstones of the Hasle Formation on Bornholm in that it includes Mendicodinium reticulatum, Tasmanites $\mathrm{sp}$. and various acritarchs (Poulsen 1992a; Koppelhus \& Nielsen 1994).

\section{Sequence Fj 5 (Lower-Upper Pliensbachian)}

Sequence $\mathrm{Fj} 5$ consists of the main part of the F-II member (F-IIa and most of the F-IIb beds of Michelsen (1989a) where F-II is subdivided) over much of the basin including the Sorgenfrei-Tornquist Zone (Fig. 21). North-east of the Børglum Fault, the sequence consists of the uppermost part of the F-II member and the lowermost part of the F-III member. With reference to the ostracod zonation, the sequence spans the upper part of the G. apostolescui-K. (K.) foveolata Subzone and the lowermost part of the O. adenticulata-N. (N.) simplex Zone (Fig. 18) of Michelsen (1975, 1989a). It spans the upper part of the L. variabile Zone and the lower part of the L. spinosa Zone (dinoflagellates), and the upper part of the C. macroverrucosus Zone (sporepollen) of Dybkjær (1991) and Poulsen (1996).

\section{Base of sequence, lowstand and transgressive systems tracts}

The lower sequence boundary (SB 13) is marked by an abrupt log-break on sonic and resistivity logs, indicating homogenous marine mudstones overlain by a succession of silty and sandy mudstones that is typically $1-10 \mathrm{~m}$ thick although locally increasing to more than $40 \mathrm{~m}$ (Fjerritslev-2). South-west of the Børglum Fault, SB 13 coincides with the base of the F-II member, and tracing of log-patterns from Hyllebjerg-1 to wells located on salt structures indicates that SB 13 is conformably developed (Fig. 21). The silty and sandy mudstones are overlain by transgressive mudstones and are interpreted as a lowstand systems tract which corresponds to the F-IIa beds of Michelsen (1989b). A core just above the base of the F-II member in Gassum-1 shows a maximum in density and diversity of ostracods indicating a well-oxygenated environment (Michelsen 1989b). The base of the F-II member occurs in the lower part of the Ibex Zone, and is interpreted to be isochronous in most of the basin.

North-east of the Børglum Fault, SB 13 occurs in the upper part of the F-II member and the lowstand systems tract consists of 10-20 m of aggrading to weakly backstepping marine sandstones (Sæby-1 and Frederikshavn wells; Fig. 22, see also Fig. 25). These are sharply overlain by marine sandstones and mudstones, 6-8 $\mathrm{m}$ thick, constituting the transgressive systems tract (Fig. 15). The mudstones contain a relatively rich and diverse ostracod fauna of the $G$. apostolescui $-K$. (K.) foveolata Subzone, including both the index fossils and $O$. moubersenis and O. amalthei, which indicate the upper Lower Pliensbachian (Michelsen 1975; O. Michelsen, personal communications 1991, 1993). A hiatus corresponding to the Margaritatus Zone and the lower part of the Spinatum Zone occurs in the Frederikshavn cores, and the transgressive systems tract is truncated by SB 15 (Figs 15, 22). Mudstones of the transgressive systems tract in both the Frederikshavn-2 and Skagen-2 wells contain dinoflagellate cysts indicative of the Nannoceratopsis gracilis Zone (Dybkjær 1991; Poulsen 1992a); integration of the ostracod and dinoflagellate data indicates the middle to upper Davoei Zone (Fig. 18). Thus TS 13 is probably situated in the Ibex Zone or in the lower Davoei Zone, as it is located just above SB 13.

\section{MFS 13, highstand systems tract and} thickness variations

MFS 13 is relatively clearly marked in the Himmerland Graben, where the sequence is 30-60 m thick, and in the Fjerritslev Trough, where the thickness increases to c. $100 \mathrm{~m}$ in the Fjerritslev-2 well, located close to the bounding fault. MFS 13 can be traced to the eastern part of the Fjerritslev Trough (Børglum-1, Flyvbjerg-1), but is not present east of the Børglum Fault (Fig. 22, see also Fig. 25). The sequence thins over salt structures with a minimum thickness of less than $5 \mathrm{~m}$ in Kvols-1, and it appears that only the part of the sequence close to the point of maximum flooding is represented (Fig. 21). The influence of the salt structures and the coarser grain size compared to sequences $\mathrm{Fj} 1-4$ suggest a shallower water depth during deposition compared to the underlying sequences.

MFS 13 occurs in the upper Lower Pliensbachian in the Børglum-1, F-1, Fjerritslev-2, Hyllebjerg-1 and 
Rønde- 1 wells. In Oddesund- 1 and Rødding-1, it occurs just below the top of the Lower Pliensbachian. In Flyvbjerg-1, MFS 13 is identified below the base of the Upper Pliensbachian. Since the available evidence indicates that the transgressive systems tract in Frederikshavn-2 belongs to the Davoei Zone, MFS 13 is referred to the Davoei Zone, where both the diversity and density of ostracods are low (Michelsen 1989b).

\section{Sequence Fj 6 (Upper Pliensbachian)}

Sequence Fj 6 consists of the upper F-II member (upper F-IIb and F-IIC) and the lower F-III member in the basin including the Sorgenfrei-Tornquist Zone (Figs 21, 22). The sequence spans the ostracod O. adenticulata $-N$. (N.) simplex Zone of Michelsen $(1975,1989$ a) with the exception of the lowermost and uppermost parts. It is referred to the L. spinosa Zone of Poulsen (1996). Sequence Fj 6 is not present on the Skagerrak-Kattegat Platform, where a hiatus corresponding to the Margaritatus Zone and part of the Spinatum Zone is indicated, as discussed under Sequence Fj 7.

\section{Base of sequence, lowstand and transgressive systems tracts, and MFS 14}

The base of the sequence is marked by a subtle change from forestepping mudstones to backstepping silty and sandy mudstones across the conformable SB 14 in the middle part of F-IIb in the Himmerland Graben. SB 14 can be traced to Børglum-1 and Flyvbjerg-1, where it is marked by a subtle change from forestepping to backstepping sandy mudstones and muddy sandstones (Fig. 22). The log change is more pronounced in wells located on salt structures, suggesting that SB 14 is sharply developed (e.g. Oddesund-1, Rødding-1, Skive-1; Fig. 21). A hiatus occurs in the upper part of the F-II member in these wells (Michelsen 1989b) indicating that non-deposition or submarine erosion prevailed on the structures during the formation of the sequence boundary. SB 14 is located in the Margaritatus Zone, occurring above the top of the Lower Pliensbachian and below log marker i, which was referred to the Margaritatus Zone by Michelsen (1989b).

The lowstand systems tract is $15-40 \mathrm{~m}$ thick, and logmotifs and cuttings samples indicate that it consists of sandy and silty mudstones and fine-grained, heterolithic sandstones which show an aggrading to weakly backstepping pattern (Figs 21, 22). It is sharply overlain by mudstones of the transgressive systems tract, which shows very smooth log-patterns in the lower part in most wells indicating 5-20 m of homogeneous marine mudstones. These are overlain by more variable mudstones showing both coarsening- and fining-upwards trends. However, the overall backstepping culminates at MFS 14, just above log marker j of Michelsen (1989b), which occurs close to the boundary between the Margaritatus and Spinatum Zones. The transgressive systems tract ranges in thickness from $c .10 \mathrm{~m}$ in Børglum-1 to more than $60 \mathrm{~m}$ in basinal sections. A core from Flyvbjerg-1 illustrates parts of two coarsening-upwards parasequences of shell-bearing mudstones and intensely bioturbated muddy, fine-grained sandstones with erosion surfaces mantled by thin shell and pebble layers.

\section{Highstand systems tract}

The highstand systems tract is up to $c .40 \mathrm{~m}$ thick and typically consists of weakly forestepping mudstones. In the eastern part of the Fjerritslev Trough, it consists of a succession of distinctly forestepping sandstones and mudstones, 20-30 m thick (Fig. 22).

\section{Sequence Fj 7 (Upper Pliensbachian - Middle Toarcian)}

Sequence $\mathrm{Fj} 7$ consists of the major part of the F-III member over most of the basin; in the eastern part of the Fjerritslev Trough and on the Skagerrak-Kattegat Platform, it includes the lowermost part of F-IV member. The lower part of the sequence corresponds to the uppermost part of the ostracod O. adenticulata $-N$. (N.) simplex Zone. This zone is overlain by a thick section that is almost barren of ostracods, providing only weak evidence of the Toarcian Stage (Michelsen 1975, 1989a, b). With reference to dinoflagellates, the sequence spans the L. spinosa Subzone b and the M. semitabulatum Subzone of Poulsen (1996).

\section{Base of sequence and lowstand systems tract}

The base of the sequence (SB 15) is clearly marked by a succession of marine shoreface sandstones, 5-12 m thick, overlying a regressive surface of marine erosion in the Børglum-1, Flyvbjerg-1, Haldager-1 and Vedsted-1 wells (Figs 22, 23). In the Himmerland Graben, SB 15 is marked by a change from marine mudstones to a succession of silty or sandy mudstones, up to $25 \mathrm{~m}$ thick, 
most clearly shown by the sonic and resistivity logs (Fig. 22). On the Skagerrak-Kattegat Platform, SB 15 is defined at the base of a very distinct peak on the gammaray $\log$ and the SP-log in the Sæby-1, Frederikshavn-1, $-2,-3$, and Skagen-2 wells. This peak was cored in Frederikshavn-2, where it is marked by less than $1 \mathrm{~m}$ of calcite-cemented marine sandstone bounded by mudstones (Figs 15, 22). The mudstones below the sandstone bed contain a rich ostracod fauna typical of the Lower Pliensbachian G. apostolescui - K. (K.) foveolata Subzone and belong to sequence $\mathrm{Fj} 5$, whereas the mudstones above the sandstone contain a fauna typical of the upper part of the O. adenticulata - N. (N.) simplex Zone, belonging to the Spinatum Zone (Michelsen 1975, 1989b; O. Michelsen, personal communication 1993). This implies a significant Upper Pliensbachian hiatus at the base of the sandstone corresponding to sequence $\mathrm{Fj} 6$ and the upper part of $\mathrm{Fj}$ 5. No evidence of subaerial exposure has been observed in the mudstones below SB 15, suggesting either that the missing section was removed by submarine erosion or that a subaerial erosion surface was obliterated by transgressive erosion. SB 15 coincides with log marker $\mathrm{k}$ of Michelsen (1989b; Figs 21, 22), and as it occurs 1-20 m below the top of the Upper Pliensbachian, it is well-dated to the upper part of the Spinatum Zone.

The shoreface sandstones and their basinwards silty mudstone equivalent constitute the lowstand systems tract, which is capped abruptly by TS 15 in the Fjerritslev Trough. TS 15 is dated to the Pliensbachian-Toarcian boundary as it coincides with, or occurs very close to, the upper boundary of the ostracod O. adenticulata$N$. (N.) simplex Zone in most well sections. Core samples from the lowstand systems tract in Fjerritslev-2 and Sæby-1 indicate the Upper Pliensbachian - lowermost Toarcian Subzone b of the dinoflagellate L. spinosa Zone (Forbes et al. 1985; Poulsen 1992a, 1996). In all the investigated well sections, L. spinosa is absent in the succeeding transgressive systems tract. In Anholt-4, L. spinosa cysts are only present in Upper Pliensbachian silty sands at the base of the borehole (Seidenkrantz et al. 1993), and disappear a few metres below a transgressive surface overlain by marine clay. It is thus likely that the lowermost part of the Anholt- 4 section belongs to the lowstand systems tract, and the transgressive surface observed in this well correlates with TS 15. The Anholt -4 section is thus considered to record the same overall development during the late Pliensbachian Early Toarcian as the other well sections in the area, contradicting the interpretation of Seidenkrantz et al. (1993; see also Nielsen et al. 2003, this volume).

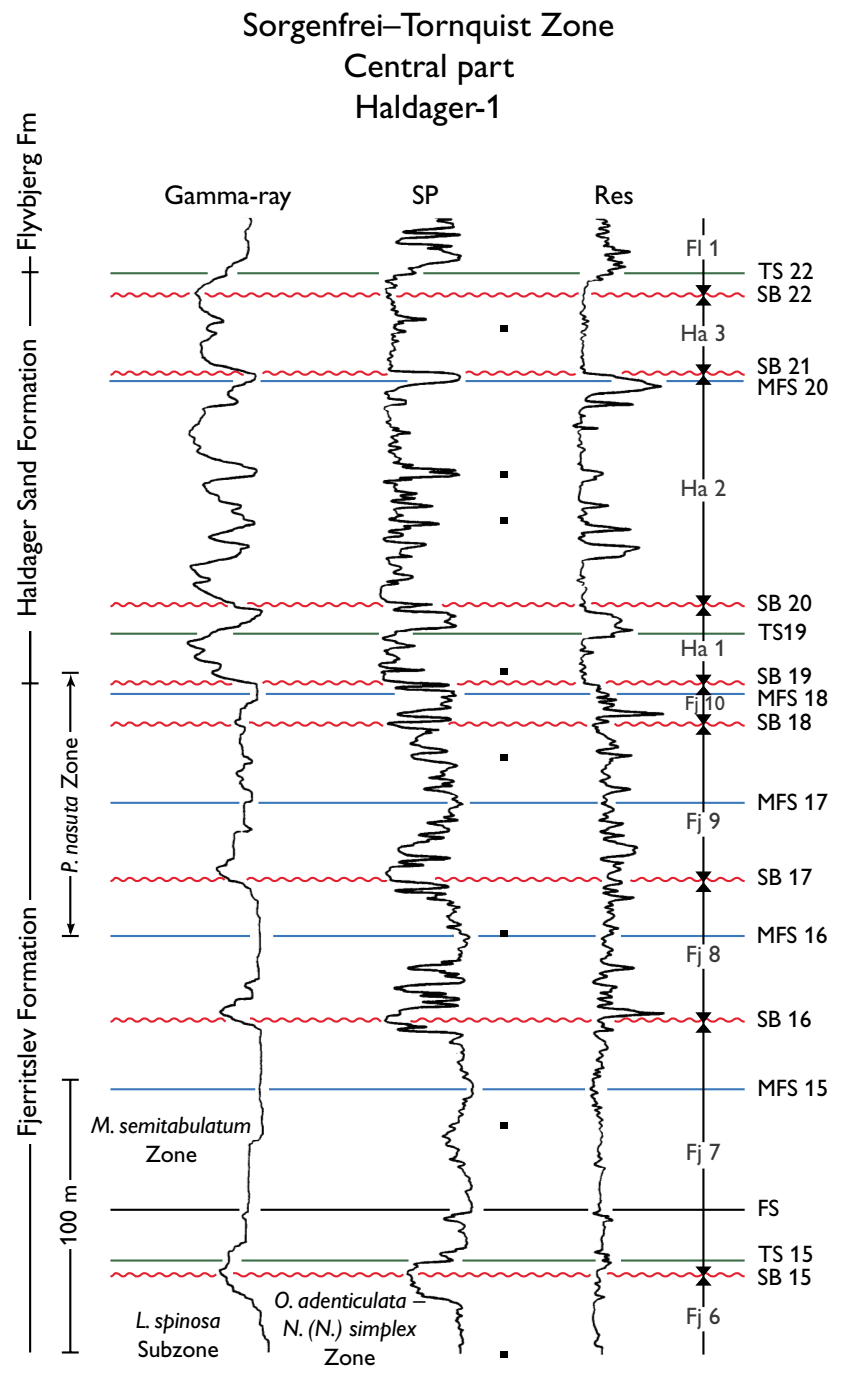

Fig. 23. Well logs from the upper part of the Fjerritslev Formation, the Haldager Sand Formation and the lowermost part of the Flyvbjerg Formation in the Haldager-1 well showing sequences, key surfaces and the position of cores. Biozones are based on Michelsen (1975) and Poulsen (1992a). Note that the top of the dinoflagellate P. nasuta Subzone is defined by a core sample of marine mudstones of the flooding surface that caps the lowermost parasequence overlying SB 19; this sequence boundary corresponds to the regional 'base Middle Jurassic unconformity', here developed as a regressive surface of marine erosion overlain by a LST of marine shoreface sandstones.

\section{Transgressive systems tract, MFS 15 and} highstand systems tract

The transgressive systems tract comprises a well-developed backstepping succession of marine mudstones and heteroliths, 15-40 m thick in most wells (Figs 21, 23). The mudstones are almost barren of ostracods except 
for pyritic casts, and contain abundant Spheripollenites psilatus together with amorphous organic matter implying reducing conditions (Michelsen 1975; Dybkjær 1991). The ostracods disappear just below TS 15 in the Fjerritslev-2, Hyllebjerg-1 and Års-1 wells, which are located in the deep parts of the basin, whereas they disappear just above TS 15 in the Frederikshavn- 1 and -2 wells located on the shallow Skagerrak-Kattegat Platform (Michelsen 1975, 1989a, b). The disappearance of the benthic ostracods thus seems to be related to the development of anoxia associated with the transgression that formed TS 15. Within the transgressive systems tract in Vedsted-1 and Haldager-1, a flooding surface is overlain by prograding units. The flooding surface corresponds to log marker 1 of Michelsen (1989b), which possibly occurs in the Tenuicostatum Zone. The marker is traced to other well sections, but the prograding pattern is not recognised elsewhere.

MFS 15 is distinctly marked by high gamma-ray, very low sonic and low resistivity values and rightwards deflection on the SP-log; severe caving of the condensed section results in anomalous values (i.e. low gamma-ray) in some wells (e.g. Hyllebjerg-1; Fig. 21). MFS 15 occurs just below log marker $\mathrm{m}$ in most wells, but is slightly above the marker in Kvols-1. The log marker is correlated to the Falciferum Zone (Michelsen 1989b). Core pieces of greyish-green mudstones from $c .10 \mathrm{~m}$ below MFS 15 in Haldager-1 and c. $10 \mathrm{~m}$ above MFS 15 in Flyvbjerg-1 yield dinoflagellates of the M. semitabulatum Subzone, which ranges from the uppermost Tenuicostatum Zone to the lower Bifrons Zone (Poulsen 1992a, 1996); this supports a Falciferum Zone age for MFS 15.

The highstand systems tract mainly consists of a succession of marine mudstones, up to $c .125 \mathrm{~m}$ thick in Fjerritslev-2, showing a weak coarsening-upwards to siltstones in the uppermost part. On the Skagerrak-Kattegat Platform, the highstand deposits contain progradational units of coarser grained mudstones.

\section{Sequences $\mathrm{Fj}$ 8, Fj 9 and $\mathrm{FJ} 10$ (Middle Toarcian - Lower Aalenian)}

The succession referred to sequences Fj 8, Fj 9 and Fj 10 consists of marine mudstones and sandstones of the F-IV member. Its top corresponds to the 'base Middle Jurassic unconformity'. The succession is almost barren of ostracods. Cores from the Vedsted-1 and Haldager-1 wells have yielded a monospecific fauna with poor stratigraphic significance, but suggesting a broad ToarcianAalenian age (Michelsen 1975, 1978, 1989b). A slightly more diverse fauna from the Øresund-2 well, supported by foraminifers, suggests an Aalenian age (Michelsen 1975). Dinoflagellate cysts of the Parvocysta nasuta Subzone have been reported from the Farsø-1, Fjerritslev-2, Haldager-1, Lavø-1, Terne-1, Vedsted-1 and Øresund-2 wells, indicating the Middle Toarcian - Lower Aalenian (Forbes et al. 1985; Poulsen 1992a, 1996).

The succession is thickest in the deep part of the Sorgenfrei-Tornquist Zone, and also occurs in the Himmerland Graben and on the Skagerrak-Kattegat Platform; only the lower part of the succession is present in the K-1, Kvols-1, Mors-1 and Rønde-1 wells, and it is absent in the southern and south-easternmost part of the basin.

In Haldager-1, three sharp-based sandstones up to $10 \mathrm{~m}$ thick occur within forestepping and backstepping marine mudstones (Figs 23, 24; Fig. 24 follows page 498). The sandstones are interpreted as shoreface sandstones overlying regressive surfaces of marine erosion implying that lowstand shorelines were established in the Sorgenfrei-Tornquist Zone during the Middle-Late Toarcian. The bases of the sandstones are interpreted as sequence boundaries, SB 16-18, which are traced to Terne-1, located on strike towards the south-east. Updip from Haldager-1, the sequence boundaries appear to be marked by thin veneers of sandstone, possibly reflecting lowstand erosion and bypass and subsequent transgressive erosion (e.g. Farsø-1, Frederikshavn-2, Vedsted-1; Fig. 24). Thin lagoonal units with coals were cored in the Skagen-2 well, in the uppermost part of the F-IV member. The member typically consists of marine mudstones and these unusual lagoonal deposits overlain by normal marine mudstones are interpreted as erosional remnants of transgressive, paralic deposits overlying sequence boundaries.

The maximum flooding surfaces of the three sequences, MFS 16-18, are only well-defined in Haldager-1 and Terne-1. Palynomorphs from core samples in Haldager-1 show that the surfaces occur in the dinoflagellate P. nasuta Subzone (Poulsen 1992a, 1996). SB 16, SB 17 and MFS 16 can be traced to the Himmerland Graben (Farsø-1) and updip to the SkagerrakKattegat Platform, but the biostratigraphic resolution is too poor to confirm the correlations (Fig. 24).

\section{Sequences $\mathrm{Ha}$ 1, $\mathrm{Ha}$ 2, $\mathrm{Ha} 3$ and $\mathrm{FI} 1$ (Aalenian-Oxfordian)}

The succession referred to sequences Ha 1, Ha 2, Ha 3 and $\mathrm{Fl} 1$ consists of the Haldager Sand Formation and the lower two-thirds of the Flyvbjerg Formation. It is 
bounded by the 'base Middle Jurassic unconformity' below and SB 23 above (Fig. 24). The succession is poorly dated as it primarily contains long-ranging spores and pollen, suggesting a broad Middle - early Late Jurassic age. In the Sorgenfrei-Tornquist Zone, however, palynomorphs indicating the Aalenian-Callovian and Oxfordian are found (Forbes et al. 1985; Dybkjær 1991; Michelsen \& Nielsen 1991; Poulsen 1992a, b, 1996; Seidenkrantz et al. 1993). The succession reaches a maximum thickness of c. $200 \mathrm{~m}$ in the Sorgenfrei-Tornquist Zone decreasing to $c .50 \mathrm{~m}$ on the Skagerrak-Kattegat Platform. In the north-west and central parts of the basin, the thickness is between 30-60 m depending on the position relative to salt structures and faults. The thickness decreases to $c .2-20 \mathrm{~m}$ in the southern and south-western part of the basin, and the succession is absent close to, and upon, the Ringkøbing-Fyn High.

\section{Sequence Ha 1}

Sequence Ha 1 is only present in the deepest part of the Sorgenfrei-Tornquist Zone. It wedges out towards the faulted margins of the Fjerritslev Trough and is absent in the Børglum-1, Fjerritslev-2, and Flyvbjerg-1 wells (Fig. 24). The base of the sequence (SB 19) is marked by a change from marine offshore mudstones of the Fjerritslev Formation to three shoreface sandstone units, $c$. 18-20 $\mathrm{m}$ thick, separated by fine-grained beds (Haldager-1, Terne-1; Figs 23, 24). Core fragments from the fine-grained beds in Haldager-1 show a weakly bioturbated heterolith containing abundant plant material, pyrite and a marine palynomorph assemblage (Ravn-Sørensen 1989; Poulsen 1992a). In Terne-1, dinoflagellate cysts, Tasmanites sp. and foraminiferal test linings occur (Forbes et al. 1985). The biostratigraphic evidence indicates that SB 19 occurs in the Lower Aalenian Opalinum Zone, just below the base of the Murchisonae Zone, as suggested below.

The sandstones are sharply overlain by transgressive mudstones and are referred to the lowstand systems tract. The upper sandstone in Terne- 1 is carbonate-cemented, a feature that is commonly seen at transgressive surfaces capping lowstand systems in the Danish Basin. The relatively gradual base of the sandstones in Terne-1 and Haldager-1 suggests that only limited shoreface erosion occurred in the deepest part of the Sorgenfrei-Tornquist Zone during the sea-level fall that produced SB 19. In contrast, SB 19 is very sharply overlain by shoreface sandstones showing a weak overall forestepping progradational pattern in
Vedsted-1 (Fig. 24). The overlying transgressive systems tract consists of backstepping parasequences with interbedded marine mudstones and sandstones $(35 \mathrm{~m}$ thick in Terne-1) overlain by forestepping parasequences defining the position of MFS 19. A similar pattern is absent in the Haldager-1 and Vedsted-1 wells, where only $6-9 \mathrm{~m}$ of mudstones and sandstones are preserved below SB 20, possibly reflecting a more shallow and proximal position than at Terne-1.

\section{Sequence Ha 2}

Sequence Ha 2 has only been identified in the deep part of the Sorgenfrei-Tornquist Zone. The base of the sequence (SB 20) is overlain by a succession of sandstones with mudstone beds and thin coaly beds; this succession is $c .45 \mathrm{~m}$ thick in Terne- 1 and Haldager-1 (Figs 23, 24). The succession comprises a basal sandstone and three fining-upwards units overlain by a coarsening-upwards unit in Haldager-1. A core from the upper fining-upwards unit consists of cross-bedded, fine- to coarse-grained, slightly pebbly sandstones and laminated siltstones with large plant fragments. The succession is capped by laminated, silty mudstones with plant fragments and non-marine palynomorphs, as shown by core pieces (Ravn-Sørensen 1989). The succession is interpreted as a basal fluvial sandstone overlain by stacked, sandy estuarine channel and lagoonal units. The lower part of the succession in Terne- 1 shows a serrated log pattern which, supported by cuttings samples, indicates a thin fluvial sandstone overlain by interbedded lagoonal sandstones and mudstones with thin coaly seams and a mixed palynomorph assemblage including N. gracilis, Tasmanites sp. and Botryococcus sp. The upper part, showing a blocky log motif, consists of 18-19 m of barrier sandstones with thin coal seams and a mixed palynomorph assemblage. The successions, especially in Terne-1, resemble a succession formed in a drowned estuary (Allen \& Posamentier 1994; Dalrymple et al. 1994), and are thus interpreted as estuarine valley-fills formed during rising sea level in the deep part of the Sorgenfrei-Tornquist Zone. The Terne-1 succession seems to reflect a slightly more seawards position than Haldager-1.

The valley-fills are overlain by weakly backstepping marine sandstones and mudstones, $26 \mathrm{~m}$ thick in Terne-1, and aggrading to weakly prograding shoreface sandstones, $15-30 \mathrm{~m}$ thick and capped by thin transgressive mudstones in Haldager-1 and Vedsted-1 (Fig. 24). The progradational pattern may reflect proximity to 
sand-rich sources, while the Terne-1 succession reflects a more seawards position. Forestepping mudstones and sandstones of the highstand systems tract, $12 \mathrm{~m}$ thick, clearly define the position of MFS 20 in Terne-1, while highstand deposits are thin or absent in Vedsted-1 and Haldager-1.

The dinoflagellate cyst $N$. gracilis has its topmost occurrence in the highstand systems tract in Terne-1 (Forbes et al. 1985), suggesting that these deposits are not younger than Early Bajocian (Poulsen \& Riding 2003, this volume). Therefore, SB 20 was most likely formed in Late Aalenian - Early Bajocian times.

\section{Sequence Ha 3}

Sequence Ha 3 is identified in the Sorgenfrei-Tornquist Zone, the most basinwards part of the Skagerrak-Kattegat Platform, in parts of the Himmerland Graben and in Felicia-1 located just outside the Fjerritslev Trough (Fig. 1). The sequence wedges out south-west of Fars $\varnothing-1$ and is absent in Hyllebjerg-1, where deep erosion is indicated below SB 22 (Fig. 25, facing page 499). It thus oversteps the limits of sequences $\mathrm{Ha} 1$ and $\mathrm{Ha} 2$. In the deepest part of the Sorgenfrei-Tornquist Zone, the base of the sequence (SB 21) is overlain by fining-upwards successions, 21-25 m thick, of coarse- to fine-grained, muddy sandstones and thin mudstones, possibly with coal seams in the upper part (Figs 23, 24). Cuttings samples from Terne-1 and cores from Haldager-1 contain a mixed assemblage of marine and freshwater palynomorphs (Forbes et al. 1985; Ravn-Sørensen 1989), and the cores comprise fine- to medium-grained, laminated, weakly bioturbated sandstone with abundant organic debris, mudstone drapes and flakes. The fining-upwards successions are interpreted as estuarine channel-fills deposited during rising sea level. Elsewhere, sequence $\mathrm{Ha} 3$ commences with fluvial sandstones, 7-25 $\mathrm{m}$ thick. The sandstones appear to occur in small channel units, 3-7 $\mathrm{m}$ thick, as suggested by subtle log fluctuations (Fig. 24). The sandstones were cored in Fars $\varnothing-1$ and Frederikshavn-1 and are sharply capped by lacustrine mudstones (Fars $\varnothing-1$ ) or lagoonal mudstones (Frederikshavn wells) reflecting a further rise in sea level (Fig. 10B). In Flyvbjerg-1, SB 21 cuts more than $50 \mathrm{~m}$ into marine mudstones of the Fjerritslev Formation relative to the neighbouring Børglum-1 well, and the overlying sandstone-dominated section is interpreted as an estuarine valley-fill (Fig. 25). Sequence Ha-3 is absent in Børglum-1 as indicated by log correlation and biostratigraphic evidence that show that the lower part of the Middle Jurassic is missing here (Ravn-Sørensen 1989). In Felicia-1, the sequence consists of c. $17 \mathrm{~m}$ of carbonaceous sandstones and mudstones with shell fragments and a terrestrially dominated palynomorph assemblage, probably representing a transgressive lagoonal unit.

Highstand deposits seem to be absent in all well sections except for Haldager-1, where $8 \mathrm{~m}$ of coarseningupwards sandstones overlying a thin mudstone are interpreted as a prograding shoreface. Palynomorphs from Felicia-1 indicate an Early Bathonian age (Stratlab a.s. 1988), and in combination with weak biostratigraphic evidence from other wells, it is suggested that SB 21 was formed in Late Bajocian - Early Bathonian times.

\section{Sequence Fl 1}

Sequence Fl 1 oversteps the limit of sequence Ha 3 and is present over most of the basin from Skagen-2 to the south-western part of the basin. It includes the topmost part of the Haldager Sand Formation and the lower two-thirds of the Flyvbjerg Formation. It shows a pronounced north-eastwards thickening (Fig. 25).

\section{Base of sequence, SB 22, lowstand and transgressive systems tracts}

The base of the sequence (SB 22) is overlain by shoreface sandstones in the deep part of the Sorgenfrei-Tornquist Zone. In the southern and south-western part of the basin, where marine mudstones of the Fjerritslev Formation are deeply truncated, SB 22 is overlain by thin and discontinuous sandstones interpreted as fluvial sandstones preserved in channel scours below the transgressive surface, TS 22 (e.g. Horsens-1, Mejrup-1, Oddesund-1; Fig. 25). Fluvial sandstones overlie lacustrine-lagoonal mudstones of sequence $\mathrm{Ha} 3$ in the Fars $\varnothing-1$, Felicia-1, Frederikshavn-2 and Vedsted-1 wells. In Skagen-2, fluvial sandstones overlie lagoonal mudstones included in the Fjerritslev Formation (Fig. 24). The sandstones are 1-18 $\mathrm{m}$ thick and were cored in the Farsø-1, Frederikshavn-1, Skagen-2, Vedsted-1 and Års-1 wells (Fig. 10B). SB 22 cuts deeply into the Fjerritslev Formation in Hyllebjerg-1 in contrast to the nearby Farsø-1 and Års-1 sections, where sequence Ha 3 is preserved below SB 22. This suggests that Hyllebjerg-1 lay structurally higher, as is also indicated by a primary thinning of the uppermost Lower Jurassic marine mudstones (F-III, F-IV members). The shoreface and fluvial 
sandstones belong to the lowstand systems tract and are erosionally or sharply overlain by transgressive lagoonal deposits or marine mudstones. The transgressive surface (TS 22) coincides with the boundary between the Haldager Sand and Flyvbjerg Formations in most of the basin. This boundary has been dated to occur just above the Callovian-Oxfordian boundary (Poulsen 1996). Biostratigraphic evidence of the Callovian Stage is poor in the Danish Basin, and a significant hiatus between the Haldager Sand and Flyvbjerg Formations was assumed by Michelsen (1989a). The interpretation presented here indicates that the formation boundary corresponds only to a diastem caused by transgressive erosion.

The transgressive systems tract shows great lateral variation in composition and thickness. In the Himmerland Graben, it is c. $5-15 \mathrm{~m}$ thick and cores (Års-1) show lagoonal deposits consisting of burrowed and rooted, wavy to lenticular bedded, occasionally wave-rippled to small-scale hummocky cross-stratified heteroliths of very fine-grained sandstones, coarse-grained siltstones and claystones. Cores from Skagen- 2 and Vedsted-1 comprise bioturbated, parallel-laminated, cross-laminated and wave-rippled sandstones and heteroliths, $2-3 \mathrm{~m}$ thick, with roots, plant fragments and brackish-marine dinoflagellates. These deposits are interpreted as transgressive lagoonal beach deposits overlying a lagoonal ravinement surface (Fig. 24). Locally, the fluvial lowstand deposits are non-erosionally overlain by muddy siltstones with rootlets and thin coal seams, indicating a gradual and gentle flooding (Frederikshavn-3). Towards the southwestern part of the basin, the systems tract thins to few metres of mudstones of presumed lagoonal origin.

In the Sorgenfrei-Tornquist Zone and on the Skagerrak-Kattegat Platform, the transgressive systems tract also includes backstepping marine deposits up to c. $30 \mathrm{~m}$ thick (Fig. 24). Cores from the Børglum-1, Flyvbjerg-1, Frederikshavn-1, -3 and Skagen-2 wells exhibit burrowed, lenticular-bedded heteroliths, laminated carbonaceous mudstones, cross-laminated siltstones and fine-grained sandstones; calcite-cemented sandstone beds with bivalve shells occur in places. The palynomorph assemblages are fairly rich in dinoflagellates showing an upwards increase in density and diversity (Forbes et al. 1985; Church et al. 1986; Ravn-Sørensen 1989; Poulsen 1992a, b). Dinoflagellate cysts of the Dichadogonyaulax sellwoodi 'group' have their topmost occurrences in the transgressive systems tract in Terne-1, indicating an age no younger than the Early Oxfordian Densiplicatum Zone (Poulsen 1996).

\section{Highstand systems tract}

The highstand deposits are very thin in the southwestern part of the basin, consisting of a few metres of mudstones (Fig. 24). The thickness increases to 5-22 m in the Sorgenfrei-Tornquist Zone and on the SkagerrakKattegat Platform, where cores consists of carbonaceous mudstones and burrowed, heterolithic, fine-grained sandstones with bivalve shells and carbonate-cemented beds (Børglum-1, Frederikshavn-1, Haldager-1, Skagen-2). Marine palynomorphs have been reported from Haldager-1 and Skagen-2 (Ravn-Sørensen 1989; Poulsen 1992a, b). The highstand deposits are thus interpreted to represent a marine offshore to lower shoreface environment. The palynomorphs of the transgressive and highstand systems tracts in the Hyllebjerg-1, Skagen-2, Terne-1, Vedsted-1 and Års-1 wells indicate a general Oxfordian age, possibly with hiati or thin biozones (Forbes et al. 1985; Poulsen 1992a, 1996). The dinoflagellates in Skagen-2 show that MFS 22 occurs in the Upper Oxfordian - lowermost Kimmeridgian Scriniodinium crystallinum Zone (Poulsen 1996; Poulsen \& Riding 2003, this volume).

\section{The upper sequence boundary, SB 23}

The upper boundary of sequence Fl 1, SB 23, is defined at the base of a unit of shell-bearing marine shoreface siltstones and sandstones, $2-10 \mathrm{~m}$ thick, in the uppermost part of the Flyvbjerg Formation in the Fjerritslev Trough. On the Skagerrak-Kattegat Platform, SB 23 is overlain by fluvial sandstones. These lowstand deposits are capped by a transgressive surface (TS 23) that is overlain by marine mudstones of the Børglum Formation in most of the basin, including the Sorgenfrei-Tornquist Zone and the Skagerrak-Kattegat Platform (Fig. 24). In the Himmerland Graben and in Felicia-1, SB 23 is marked by a change from forestepping to backstepping marine parasequences, and the boundary between the Flyvbjerg and Børglum Formation appears to be conformable. The base of the Børglum Formation occurs just above the Oxfordian-Kimmeridgian boundary in most of the basin, with a weak younging trend towards the northeast (Poulsen 1992a, b, 1996). SB 23 is thus dated to the uppermost Oxfordian.

\section{Discussion}

The sequence stratigraphic interpretation described in detail above and summarised in Figures 25 and 26 pro- 
vides the basis for an improved understanding of the Late Triassic - Jurassic evolution of the Danish Basin, both in terms of intrinsic (i.e. intrabasinal) and extrinsic (regional or global) controlling factors.

\section{Timing and cause of formation of the regional intra-Aalenian unconformity}

The 'base Middle Jurassic unconformity' is the most significant unconformity within the Upper Triassic - Jurassic succession in the Danish Basin and the Fennoscandian Border Zone (Figs 10B, 11B, 21, 24-26). In most of the basin, it is a pronounced seismic unconformity that shows progressively deeper truncation of the Lower Jurassic Fjerritslev Formation and older formations towards the Ringkøbing-Fyn High. The unconformity is also developed as a significant erosion surface on the Skagerrak-Kattegat Platform, whereas it passes into a seismic conformity in the deep part of the SorgenfreiTornquist Zone. The overlying succession shows an Upper Aalenian - Volgian onlap onto the unconformity surface with a pronounced younging of the onlap towards the Ringkøbing-Fyn High. Jurassic deposits are eroded on the high, and Lower Cretaceous strata onlap eroded Triassic deposits or Precambrian crystalline basement. The 'base Middle Jurassic unconformity' thus subdivides the Upper Triassic - Jurassic succession into two principal tectono-stratigraphic units.

Formation of the deep, erosional unconformity required major uplift of the Ringkøbing-Fyn High and large parts of the basin (Fig. 27). The onlap of the overlying strata shows that accommodation space was subsequently created due to renewed subsidence, as the eustatic sea-level rise alone cannot account for the onlap pattern. The unconformity is most precisely dated in the Sorgenfrei-Tornquist Zone, where it passes into a relatively conformable, regressive surface of marine erosion (SB 19). Generally, biostratigraphic information from the Toarcian-Aalenian deposits is poor, reflecting the restricted nature of the basin at this time, but data from the Anholt-4, Børglum-1, Fjerritslev-2, Haldager-1, Terne-1, Vedsted- 1 and Øresund- 2 wells indicate that deposition of marine mudstones and siltstones continued uninterrupted from Early Jurassic into Aalenian times in the Sorgenfrei-Tornquist Zone (Michelsen 1975; Forbes et al. 1985; Ravn-Sørensen 1989; Dybkjær 1991; Michelsen \& Nielsen 1991; Poulsen 1992a, b, 1996; Seidenkrantz et al. 1993). The top of the Upper Toarcian - Lower Aalenian P. nasuta Zone (dinoflagellates) is found above SB 19 in core samples of mudstones in
Haldager-1 (Poulsen 1992a, b, 1996) from the flooding surface capping the lowermost parasequence of the lowstand systems tract of sequence Ha 1 (Fig. 23). The top of the P. nasuta Zone coincides with the OpalinumMurchisonae Zone boundary (Poulsen \& Riding 2003, this volume), and as Aalenian marine mudstones are identified below SB 19, it is most likely that SB 19 occurs in the Lower Aalenian Opalinum Zone, just below the base of the Murchisonae Zone. Thus the age of the pronounced basinwards shift in facies across the 'base Middle Jurassic unconformity' in the Sorgenfrei-Tornquist Zone corresponds to the major basinwards shift in facies at the 'mid-Cimmerian Unconformity' in the North Sea (Underhill \& Partington 1993, 1994) and the major $177 \mathrm{Ma}$ sequence boundary of Haq et al. (1988).

The regional 'mid-Cimmerian Unconformity' in the North Sea has been interpreted to reflect uplift and erosion related to emplacement of a mantle plume (Whiteman et al. 1975; Hallam \& Sellwood 1976; Eynon 1981; Ziegler 1990; Underhill \& Partington 1993, 1994), a major eustatic sea-level fall (Haq et al. 1988), or local response to footwall uplift (Barr 1987; Badley et al. 1988). Underhill \& Partington $(1993,1994)$ portrayed a roughly circular pattern of the subcrop stratigraphy of the unconformity $c .800 \mathrm{~km}$ in diameter and centred over the junction of the Central Graben, the Moray Firth and the Viking Graben. Based on this pattern, they interpreted domal uplift and erosion followed by deflation and gradual onlap. However, in their contouring of the crucial subcrop stratigraphy, Underhill \& Partington $(1993,1994)$ assumed that missing sections on highs such as the East Shetland Platform, the Mid

\section{Facing page:}

Fig. 26. Schematic time-stratigraphic SW-NE section from the Ringkøbing-Fyn High (RKF) across the Danish Basin and the Sorgenfrei-Tornquist Zone (STZ) to the Skagerrak-Kattegat Platform (SKP) showing depositional sequences and environments, related to the chronostratigraphy and lithostratigraphy. Sequence stratigraphic key surfaces are drawn at their most likely age: The diagram illustrates the deep erosional truncation of the pre-Lower Aalenian strata and Upper Jurassic onlap, younging towards the RKF. The 'base Cretaceous unconformity' merges with the 'base Middle Jurassic unconformity' close to the high, and Cretaceous strata overlie Precambrian basement on the RKF. The numerous hiati on the Skagerrak-Kattegat Platform illustrate the limited accommodation space here due to relatively slow subsidence in Norian-Callovian times. The duration of the Middle Jurassic hiati is poorly constrained. Time-scale from Gradstein et al. (1994). 


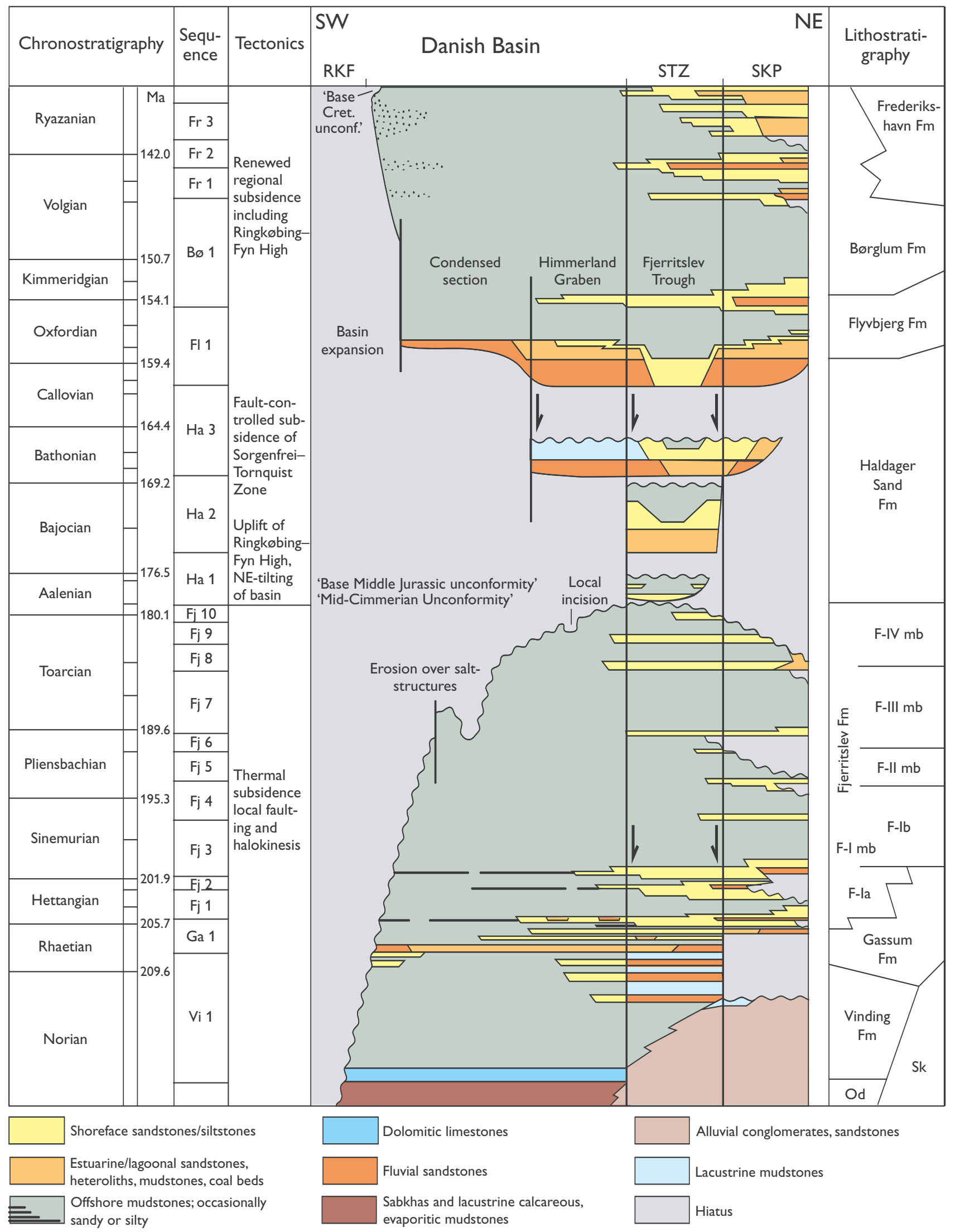


North Sea High and the Ringkøbing-Fyn High reflect local erosion due to younger footwall uplift or other factors that overprint the regional pattern. Based on this assumption, contours were connected across the Ringkøbing-Fyn High.

The contours of the subcrop stratigraphy of the unconformity in the Danish Basin roughly follow the trend of the Ringkøbing-Fyn High (Fig. 28A). The same pattern is probably present in the North German Basin south of the high, although the 'base Cretaceous unconformity' partly masks the pattern, as post-Aalenian Jurassic deposits are missing in the Danish wells from this area. The onlap pattern also parallels the general trend of the Ringkøbing-Fyn High (Fig. 28B) and, together with the subcrop contours, testifies that the high including its northern and southern flanks were uplifted, eroded and later submerged resulting in the regional
intra-Aalenian unconformity. The unconformity can probably be traced to the Rønne Graben, where Lower Aalenian(?) shoreface sandstones are unconformably overlain by Aalenian(?)-Bajocian fluvial conglomerates (Koppelhus \& Nielsen 1994). The unconformity also occurs in Skåne, where marine sedimentation continued until the end of the Early Jurassic followed by continental and paralic deposition in Middle Jurassic time reflecting tectonic uplift and erosion over much of southern Sweden, with the exception of the south-western part of Skåne, Hanö Bay and a narrow fault-controlled belt across central Skåne (Norling \& Bergström 1987; Norling et al. 1993; Erlström et al. 1997; Ahlberg et al. 2003, this volume). The age of the unconformity is not precisely determined, but appears to occur in the Aalenian. The present-day distribution of the Jurassic deposits is strongly influenced by later inversion and

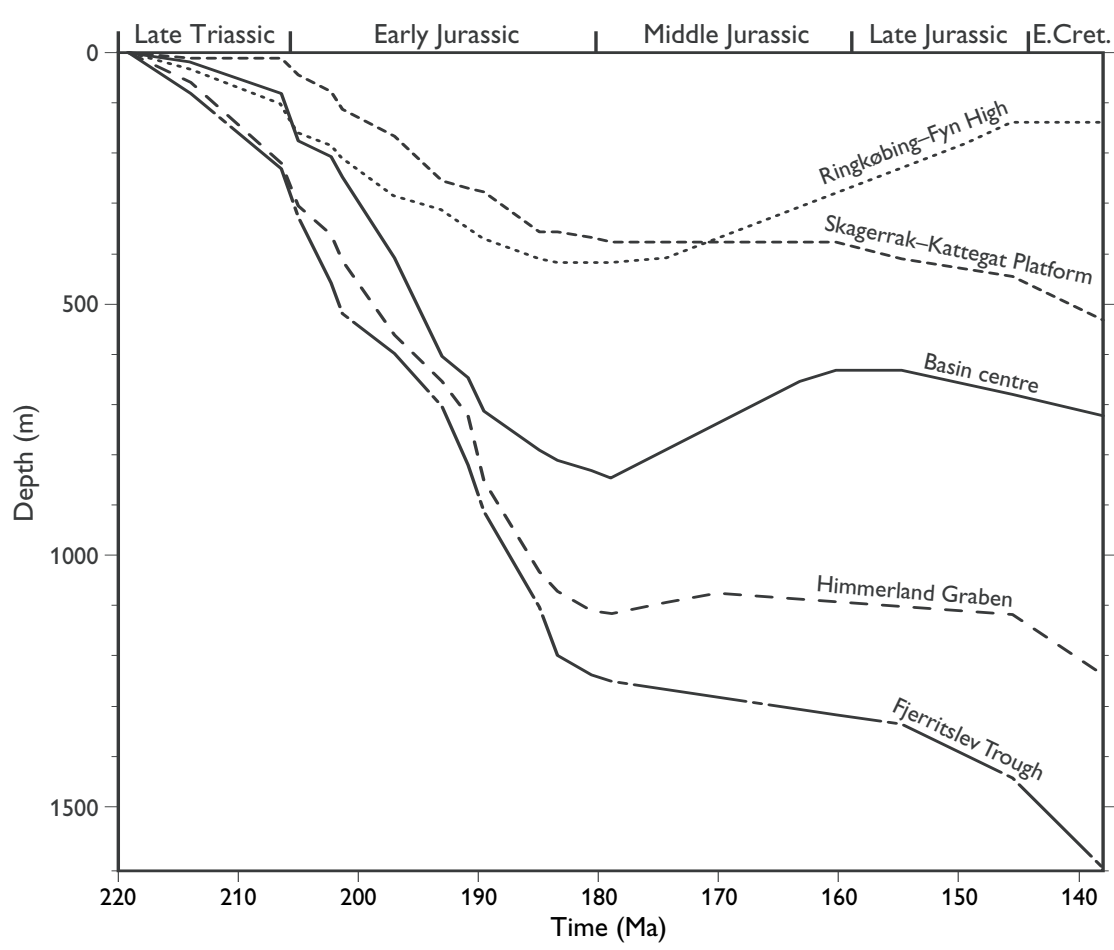

Fig. 27. Subsidence curves for five selected positions representing the Ringkøbing-Fyn High (Ullerslev-1), the distal Danish Basin (Mejrup-1), the Himmerland Graben (Hyllebjerg-1), the Fjerritslev Trough (Vedsted-1, Haldager-1) and the Skagerrak-Kattegat Platform (Sæby-1). The curves are constructed by the use of the Yükler 1D forward modelling program (Yükler et al. 1978); this adopts specified, decompacted lithologies and the time of formation of each model event corresponds to the sequences described herein (timescale of Gradstein et al. 1994). The latest event essentially corresponds to the Kimmeridgian-Ryazanian Frederikshavn Formation. Water depth that varied between 0-50 $\mathrm{m}$ during deposition of the sequences was averaged to $0 \mathrm{~m}$ to facilitate modelling and to reduce the effects of rapid sea-level fluctuations. The lithology and thickness of eroded sequences was determined from palaeogeography and by comparison to preserved sections. The five curves emphasise the Aalenian-Callovian uplift of most of the area, with the exception of the fault-bounded Sorgenfrei-Tornquist Zone (Fjerritslev Trough), where subsidence continued with a low rate in the Middle Jurassic. The curves also indicate that regional subsidence gradually resumed during the Late Jurassic - Early Cretaceous in most of the basin. 

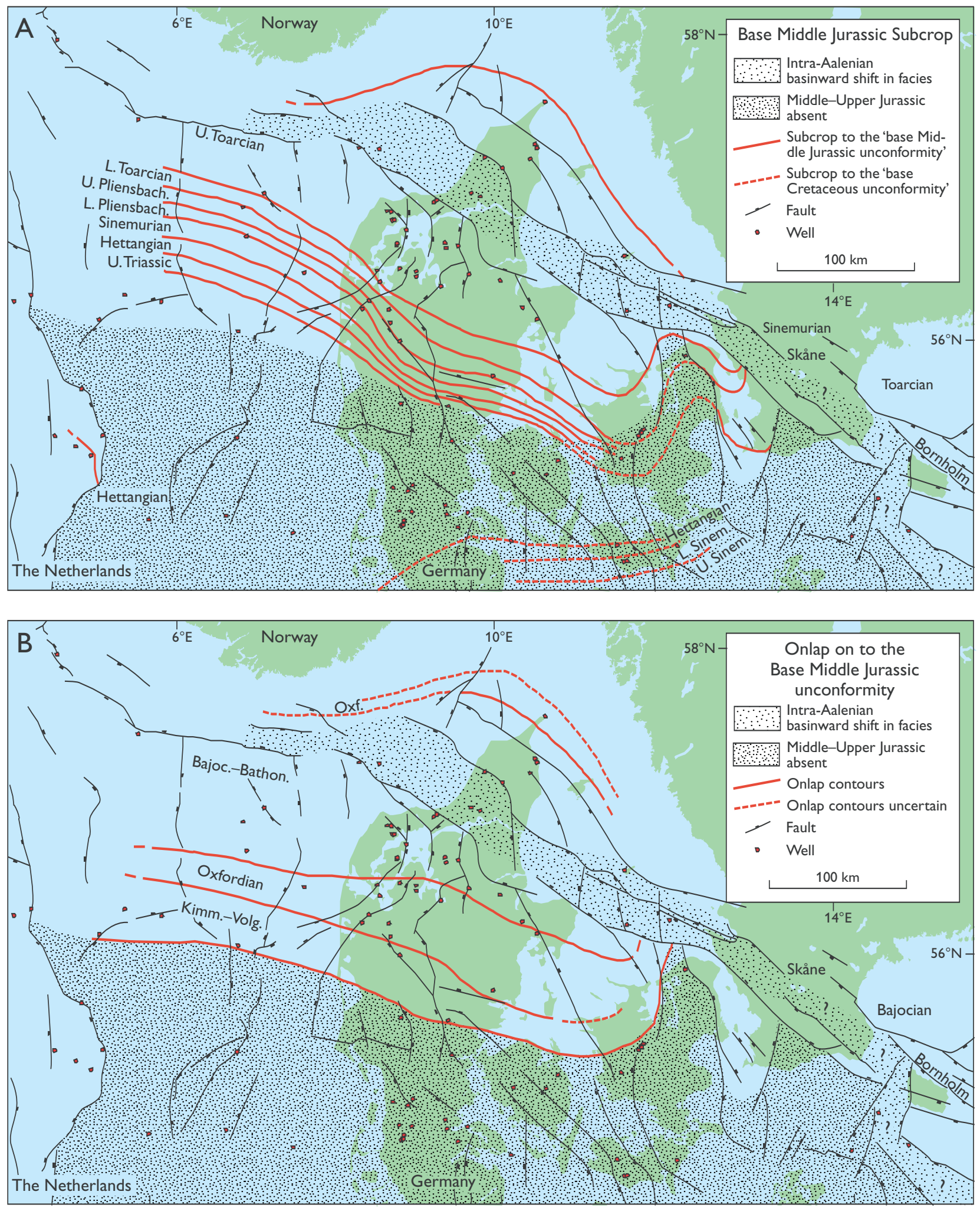

Fig. 28. A: Generalised subcrop contour map of the 'base Middle Jurassic unconformity'. The contours are based on the recognised sequences, lithostratigraphy from Nielsen \& Japsen (1991), age determinations from Dybkjær (1991), Poulsen (1996), Norling \& Bergström (1987) and Erlström et al. (1997). Sinemurian (Sinem.) deposits are preserved NE of the Sorgenfrei-Tornquist Zone in Skåne, while Toarcian deposits occur in Hanö Bay. B: Generalised contour map showing the onlap to the 'base Middle Jurassic unconformity'. Bajocian deposits occur in Hanö Bay. Both the subcrop contours (A) and the onlap contours (B) parallel the general trend of the Ringkøbing-Fyn High. Bajoc., Bajocian; Bathon., Bathonian; Oxf., Oxfordian; Kimm., Kimmerigian; Volg., Volgian. 


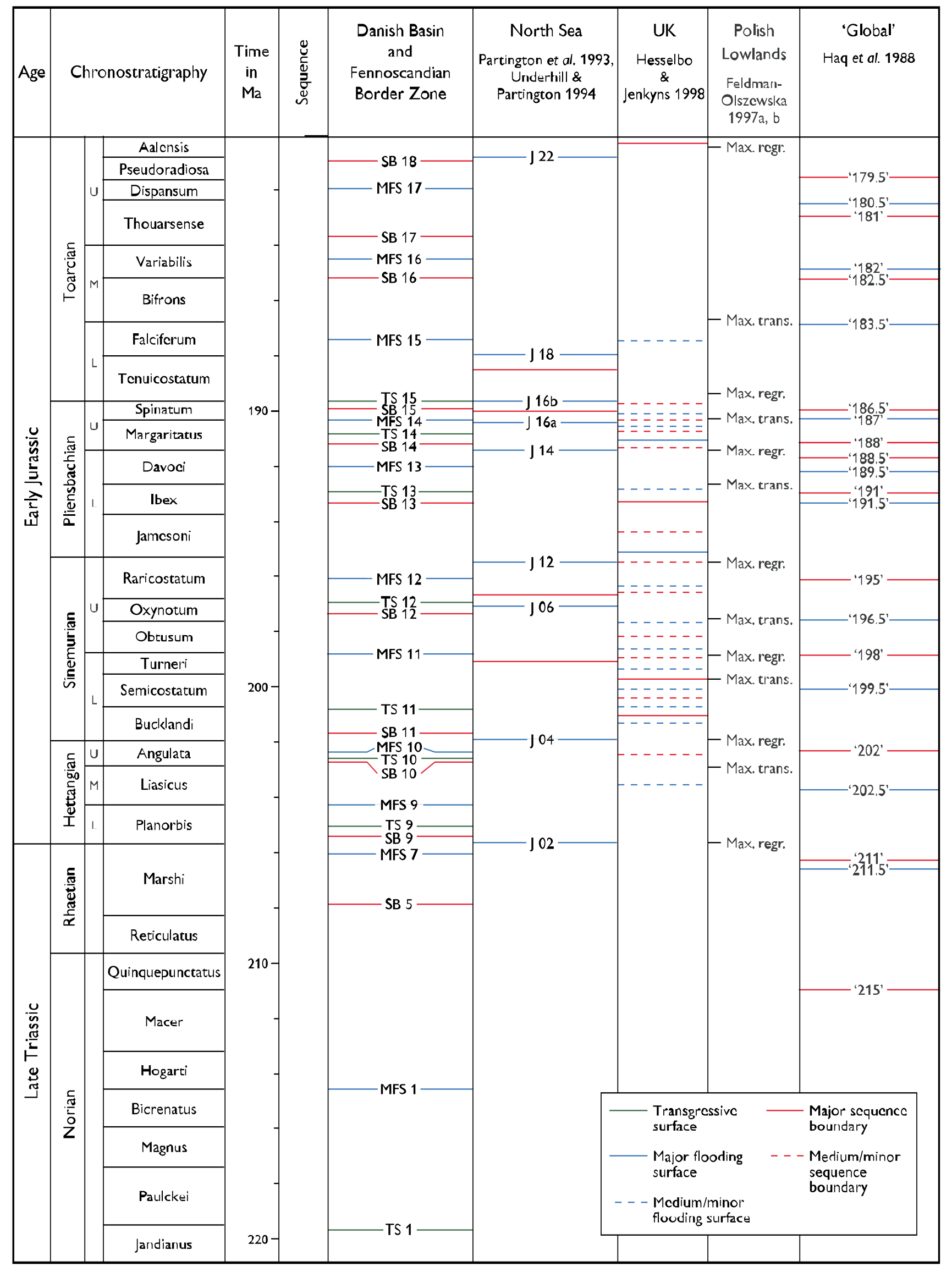


erosion, but sedimentation was probably most continuous in the Sorgenfrei-Tornquist Zone (Norling \& Bergström 1987; Erlström et al. 1997). Basalts were intruded along NW-SE-trending faults and fracture zones; the oldest basalts are palaeomagnetically dated to the Toarcian-Aalenian and radiometrically dated to the Bajocian (167 Ma), while related tuffites are dated to the Aalenian by palynology (Printzlau \& Larsen 1972; Tralau 1973; Klingspor 1976; Norling \& Bergström 1987; Bylund \& Halvorsen 1993).

The roughly circular pattern of the subcrop contours shown by Underhill \& Partington $(1993,1994)$ thus con-

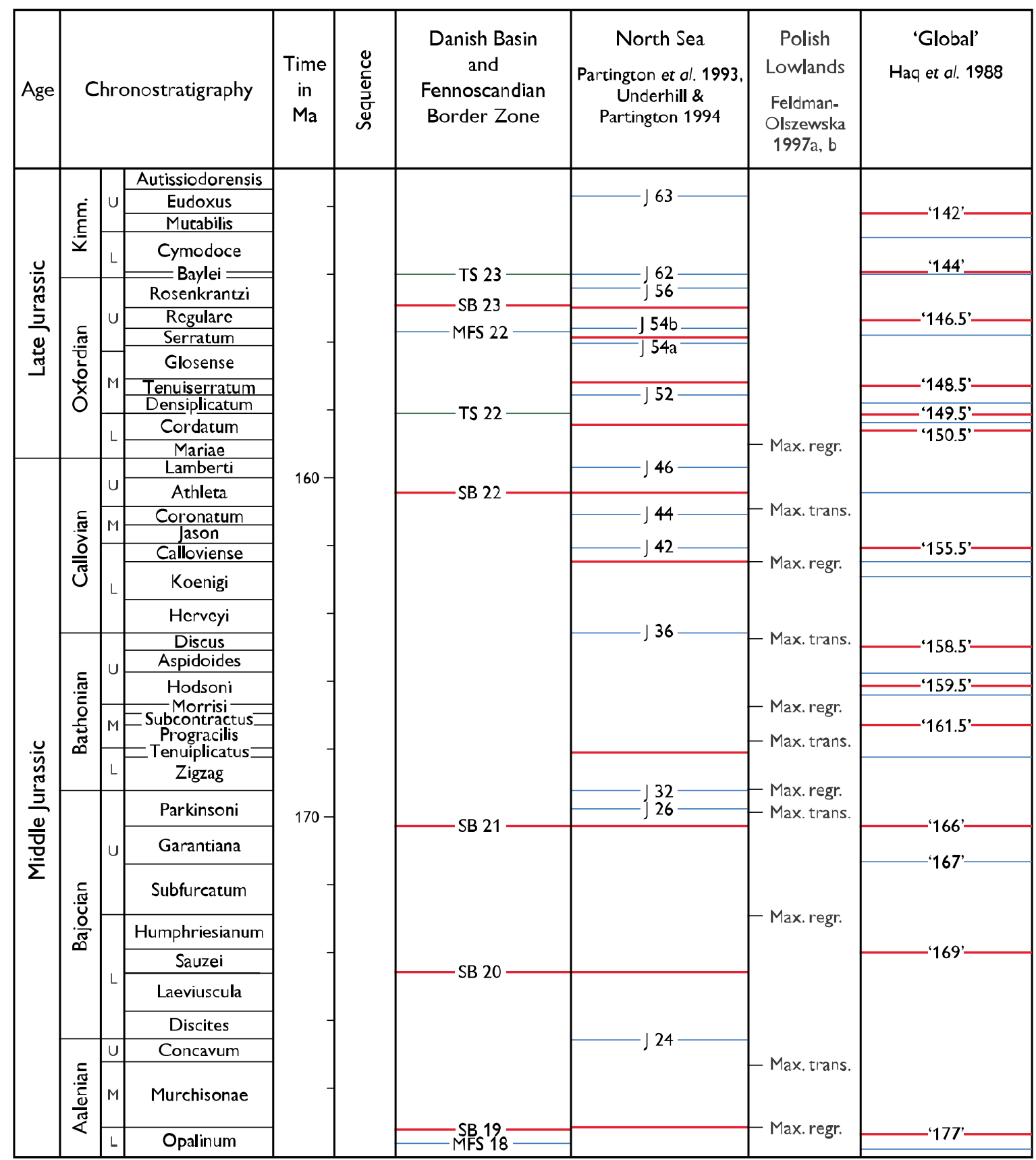

This and facing page:

Fig. 29. Comparison of third-order sequence stratigraphic key surfaces from the Danish Basin and the Fennoscandian Border Zone with 'global' surfaces recognised by Haq et al. (1988), North Sea surfaces documented by Partington et al. (1993) and Underhill \& Partington (1994), those from Poland by Feldman-Olszewska (1997a, b), and from the UK by Hesselbo \& Jenkyns (1998). Timescale from Gradstein et al. (1994); note that the numbers attached to the Haq et al. (1988) surfaces relate to the original ages ascribed by these workers, included here solely for ease of reference. 
flicts with data from the Danish Basin and Fennoscandian Border Zone. Their model underestimates the areal effect of the North Sea domal uplift and overlooks the possibility of at least one more dome centred in Skåne. Rather than suggesting a major circular to elliptical North Sea dome, the contours suggest a broad uplifted area, as has also been suggested by Ziegler $(1982,1990)$. In addition, the role of the long-lived SorgenfreiTornquist Zone has to be considered, as this fundamental fracture zone forms a buffer zone between the Danish Basin and the Baltic Shield that has accommodated Late Palaeozoic - Mesozoic transtension, has experienced phases of volcanic activity (Late Carboniferous - Early Permian, Middle Jurassic, Cretaceous) and has undergone Late Cretaceous - early Cenozoic transpression resulting in tectonic inversion. Contemporaneous with the regional Aalenian-Bajocian uplift, slow subsidence occurred in the Sorgenfrei-Tornquist Zone and this zone of crustal weakness probably functioned as a hinge zone between the north-eastwards tilting basin and the Baltic Shield. Thus, a model explaining both North Sea uplift and volcanism, uplift of the Danish Basin and the Ringkøbing-Fyn High, and uplift and volcanism in Skåne probably has to invoke lithospheric processes on a larger scale than a single transient plume.

\section{Comparison of the sequence stratigraphic key surfaces to other schemes}

The third-order sequence stratigraphic key surfaces from the Danish Basin and the Fennoscandian Border Zone can be compared and contrasted with those presented by Haq et al. (1988), Partington et al. (1993; Underhill \& Partington 1994), Feldman-Olszewska (1997a, b) and Hesselbo \& Jenkyns (1998; Fig. 29). The Haq et al. (1988) chart is claimed to portray a global, eustatic signal, while the compilations of Partington et al. (1993) and Underhill \& Partington (1994) are based on data from the large North Sea Basin, of which the Danish Basin formed a part. Hesselbo \& Jenkyns (1998) compared the Lower Jurassic sequence stratigraphies of several British basins whereas FeldmanOlszewska (1997a, b) described surfaces of maximum regression and maximum transgression from the Polish Basin. The potential error of the assigned ages of the Upper Triassic - Lower Jurassic and Upper Jurassic surfaces in the Danish area may amount to more than one standard zone in some cases. The number of Upper Triassic - Lower Jurassic sequences in the Danish area equals that of Haq et al. (1988), whereas Partington et al. (1993) and Underhill \& Partington (1994) recognised many fewer sequences. Although the most recent, well-constrained time-scale (Gradstein et al. 1994) is adopted here, the Haq et al. (1988) surfaces are referred to according to their original age assignments. Thus the MFS originally dated at $223 \mathrm{Ma}$ is abbreviated here to 'MFS 223', although its position has been re-calibrated to Gradstein et al. (1994) on Figure 29. Partington et al. (1993) utilised maximum flooding surfaces to bound their sequences; these are numbered sequentially (J16 etc.).

A detailed comparison indicates differences in the poorly dated Upper Triassic, where the 'MFS 223' of Haq et al. (1988) occurs at the Carnian/Norian boundary, while MFS 1 probably occurs in the Upper Norian, and SB 5 in the Early Rhaetian where Partington et al. (1993) indicate a basinwards shift in facies. In contrast, MFS 7 is well-dated to the uppermost Rhaetian by ostracods and palynomorphs supported by ammonites, and is interpreted to correspond to 'MFS 211.5' of Haq et al. (1988) and J02 of Partington et al. (1993). SB 9 occurs in the lowermost Hettangian, and is correlated with the regional significant base Hettangian unconformity at the basin margins in Skåne, Bornholm, Poland and Germany (Troedsson 1948; Gry 1969; Dadlez 1976; Lund 1977; Guy-Ohlson 1981; Gravesen et al. 1982; Sivhed 1984; Hallam 1988, 1992, 1997; Bloos 1990; Pieńkowski 1991; Norling et al. 1993; Ahlberg \& Arndorf 1994; Surlyk et al. 1995; Feldman-Olszewska 1997a), whereas Haq et al. (1988) positioned their 'SB 211' in the uppermost Rhaetian.

MFS 9 and 'MFS 205.5' of Haq et al. (1988) indicate an early-middle Hettangian maximum flooding in accordance with Hesselbo \& Jenkyns (1998), whereas Partington et al. (1993) indicate a regression. MFS 10 is dated to the uppermost Hettangian or lowermost Sinemurian, possibly corresponding to the J04 of Partington et al. (1993) and the MFS indicated in the Bucklandi Zone by Hesselbo \& Jenkyns (1998). SB 11 occurs in the Bucklandi Zone in a similar position to a major sequence boundary in the British basins (Hesselbo \& Jenkyns 1998) and a maximum regression surface in the Polish Basin (Feldman-Olszewska 1997a); Haq et al. (1988) indicated their 'SB 202' just below the Hettangian-Sinemurian boundary.

MFS 11 in the Turneri Zone, SB 12 in the Oxynotum Zone and MFS 12 in the Raricostatum Zone all seem to be 1-2 ammonite zones out of phase relative to the Haq et al. (1988) chart and surfaces identified in the British basins, the North Sea and Poland (Fig. 29). Their ages are based mainly on ostracod zonation, however, and 
Fig. 30. Comparison of proposed eustatic and regional sea-level curves with the relative sea-level curve for the Danish Basin. Curves A-C have been re-scaled according to the time-scale of Gradstein et al. (1994). Note the overall positive correlation for the Lower Jurassic; the Middle Jurassic part of the Danish curve is poorly constrained.

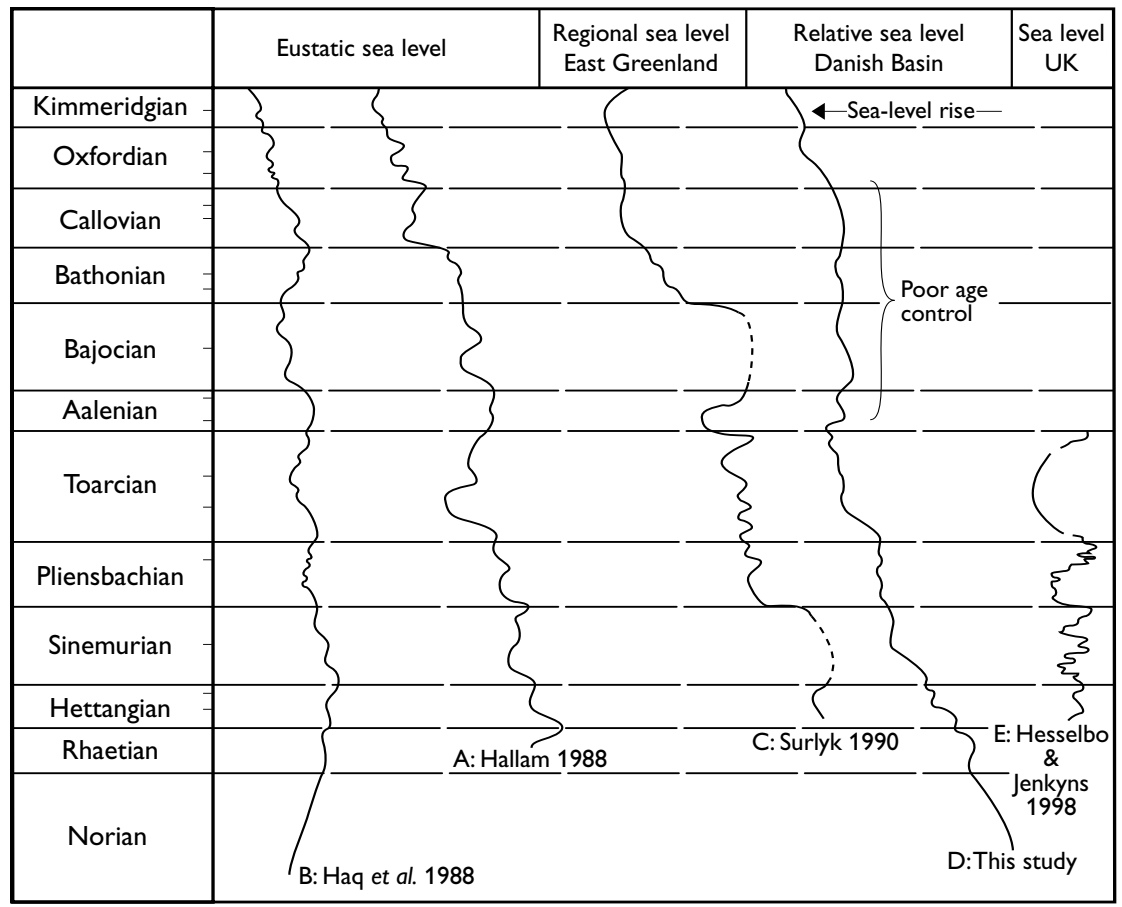

there are some uncertainties related to the correlation to ammonite zones at these levels. For instance, the $P$. reticulata Subzone is correlated with the Turneri Zone by Michelsen (1975), with the Turneri-Obtusum Zones by Sivhed (1980) and with the Obtusum Zone by Park (1987). Furthermore, the position of MFS 11 has been difficult to define in the distal and best-dated successions of homogeneous mudstones. These uncertainties may explain some of the difficulties in correlation of the Sinemurian surfaces from the Danish Basin to Skåne, Poland and Britain.

In contrast, the Lower Pliensbachian - Lower Toarcian SB 13, MFS 13, SB 14, MFS 14, SB 15 and MFS 15 all occur in the same ammonite zones as the corresponding surfaces on the Haq et al. (1988) chart and correlate quite well with the surfaces of Partington et al. (1993), Feldman-Olszewska (1997a) and Hesselbo \& Jenkyns (1998).

Three Middle Toarcian - Lower Aalenian sequences, Fj 8-10, are preserved in the Sorgenfrei-Tornquist Zone, corresponding to three sequences on the Haq et al. (1988) chart. Partington et al. (1993) indicated a maximum flooding surface in the uppermost Toarcian, whereas Feldman-Olszewska (1997a) and Hesselbo \& Jenkyns (1998) indicated a sequence boundary at this level. SB 19 corresponds precisely to the basinwards shift in facies that Underhill \& Partington (1993, 1994) indicated at the top of the Opalinum Zone, coinciding with 'SB 177' of Haq et al. (1988).

The Middle Jurassic sequences in the Danish Basin are few compared to Haq et al. (1988); they are poorly dated and their position in the scheme is uncertain. The Upper Oxfordian MFS 22 may correspond to 'MFS 147 ' and J54b, and SB 23 may correspond to 'SB 146.5'.

\section{Comparison of sea-level curves}

A relative sea-level curve has been constructed for the central parts of the Danish Basin including the Sorgenfrei-Tornquist Zone based on the sequence stratigraphic framework (Fig. 30). Sequence boundaries and maximum flooding surfaces correspond to curve segments from inflection points to lows and tops, respectively, and the overall trend of the curve is determined by the areal extent of the sequences and the palaeowater depth indicated by facies. The Lower Jurassic sequences were partly removed by erosion in the southwestern parts of the basin owing to uplift, and Middle Jurassic sediments were not deposited there or over the Ringkøbing-Fyn High. The Skagerrak-Kattegat Platform experienced relatively slow subsidence and parts of the Upper Pliensbachian were thinly developed and eroded, and Upper Aalenian - Bajocian sed- 
iments were probably not deposited (Fig. 26). Hence, the Toarcian part of the sea-level curve is based primarily on data from the Himmerland Graben and the Sorgenfrei-Tornquist Zone, whereas the Middle Jurassic part is based primarily on data from the SorgenfreiTornquist Zone. Thus, strictly speaking, the whole curve is only valid for the Sorgenfrei-Tornquist Zone. The Late Triassic - Early Jurassic part of the curve is, however, valid for most of the basin as subsidence was relatively uniform during this time interval.

Four sea-level curves are selected for detailed comparison (Fig. 30). The curves of Hallam (1988) and Haq et al. (1988) are claimed to be essentially eustatic. The curve of Hesselbo \& Jenkyns (1998) is based on the British Lower Jurassic, and the East Greenland curve of Surlyk $(1990,1991)$ represents the western margin of the major Jurassic seaway of which the Danish Basin formed a part.

It is generally accepted that a significant transgression occurred in northern Europe shortly before the end of the Triassic followed by a rapid regression more or less at the Triassic-Jurassic boundary (Hallam 1992, 1997). The well-preserved succession in the Danish Basin, however, indicates that the late Triassic transgression occurred in two major steps, one in the late Norian and one in the latest Rhaetian, separated by a significant fall in the late early Rhaetian. In addition, the sea-level fall at the Rhaetian-Hettangian boundary seems to be of much smaller magnitude than that shown by Hallam (1988) and Haq et al. (1988), and suggested by sections in Poland and Germany, where significant fluvial incision is observed (Bloos 1990; Pieńkowski 1991; Hallam 1992). A sea-level rise followed very shortly afterwards, in the Planorbis Zone. The Danish curve indicates two maxima, one in the middle Hettangian and one in the late Hettangian, while the other curves only indicate one in the middle-late Hettangian. All five curves indicate a fall close to the Hettangian-Sinemurian boundary. An extensive transgression began in the Danish Basin in the Early Sinemurian Bucklandi Zone (probably the upper part), as also recorded in the British curve. The sea-level rise is more marked on the Hallam (1988) curve than on the Haq et al. (1988) curve. In Germany, two periods of rapid sea-level rise have been recognised in the Early Jurassic, in the Planorbis Subzone and the Bucklandi Subzone (Bloos 1990), as also evident in the Danish Basin. The mid-Sinemurian maximum and Late Sinemurian low of the Danish curve is slightly out of phase with the Hallam (1988) and Haq et al. (1988) curves, which may reflect uncertainties in the biostratigraphic dating, as previously mentioned.
The detailed British curve shows two general maxima and two general lows, of which the Late Sinemurian low may correspond to that recorded in the Danish Basin. A rise beginning in the latest Sinemurian is shown by both the Danish and British curves; Surlyk (1990) shows a large rise at the Sinemurian-Pliensbachian boundary, whereas Hallam (1988) and Haq et al. (1988) indicate that the rise first started in the Early Pliensbachian. All the curves show a low in the mid- to late Pliensbachian (at or close to the boundary of the Davoei-Margaritatus Zones), and they all show a maximum in the uppermost Pliensbachian (Spinatum Zone). The Danish, British, and eustatic curves all agree on a rapid rise in the Early Toarcian, and a major fall is indicated in the Early Aalenian by the eustatic curves and the Danish curve.

The Middle Jurassic part of the Danish curve is steep and smooth reflecting the thin and poorly dated sequences of proximal facies. The corresponding part of the other curves are quite different. The Hallam (1988) and Surlyk (1990) curves emphasise a Bathonian rise, whereas the Haq et al. (1988) curve shows a large fall. The late Callovian - Kimmeridgian part of the Danish curve shows a rise, as in the other curves.

The differences in the Early Jurassic sea-level curves are relatively small and may reflect different emphasis in the interpretations, uncertainties in the dating or local subsidence patterns in the Danish Basin. However, the general positive correlation with the other curves favours a eustatic cause for the long-term trend. Furthermore, some of the short-term sea-level changes, for instance the maxima of the middle-late Hettangian, the Early Pliensbachian, the Late Pliensbachian and the Early Toarcian, and the lows at the end of the Early Pliensbachian and the end of the Late Pliensbachian may also reflect eustatic changes, if the Hallam (1988) and Haq et al. (1988) curves reflect real eustatic changes. The curves may in part be biased by regional North European sea-level changes, caused by large scale intraplate stresses of the kind proposed by Cloetingh (1988) rather than global changes (see discussion in Miall 1994).

In contrast, the Middle Jurassic part of the Danish curve clearly reflects the tectonic influence involving regional uplift of the Ringkøbing-Fyn High, north-eastwards tilting of the basin and strong reduction in subsidence rate in the Sorgenfrei-Tornquist Zone. Similar and roughly contemporaneous tectonic influences have been recognised in other parts of the Jurassic seaway (Hallam \& Sellwood 1976; Surlyk 1977, 1978; Eynon 1981; Underhill \& Partington 1993). Approximately 150-170 m of paralic sediments were deposited in the 
Sorgenfrei-Tornquist Zone and a large proportion of the necessary accommodation space could be related to eustatic sea-level rise, if the curve of Haq et al. (1988) is correct.

\section{Correlation from the deep basin to the basin margin}

The Rhaetian to Early Jurassic was a period of relative tectonic tranquillity and uniform subsidence. Deposition was to a large extent controlled by regional sea-level changes that influenced most of the depositional basin including the basin margins in Skåne and Bornholm. A chronostratigraphic scheme of the Danish Basin and Fennoscandian Border Zone is presented here (Fig. 31) showing the Rhaetian (in part) to Lower Aalenian sequence stratigraphic key surfaces, depositional environments, biozones and lithostratigraphy to facilitate comparison of the deeply-buried marine basinal successions of the Danish Basin with marginal successions in Skåne and Bornholm. The sequence stratigraphic interpretation of the Hettangian-Aalenian succession from Bornholm is based on Koppelhus \& Nielsen (1994), Nielsen (1995), Petersen \& Nielsen (1995) and Surlyk et al. (1995), while detailed sequence stratigraphic interpretations of the succession in Skåne are only documented for the Sinemurian (Erlström et al. 1999; Frandsen \& Surlyk 2003, this volume). The preliminary correlation to the Danish Basin is thus based on descriptions of the Rhaetian-Sinemurian depositional facies (Troedsson 1951; Pieńkowski 1991; Ahlberg 1994; Ahlberg \& Arndorff 1994; Erlström \& Guy-Ohlson 1999), and lithostratigraphy (Sivhed 1984; Norling et al. 1993; Ahlberg et al. 2003, this volume).

The pronounced fluvial incision surface (SB 5$)$ in the Lower Rhaetian of the Danish Basin is correlated with the base of the Bjuv Member in Skåne and it is suggested that coal seams A and B were formed during the middle-upper Rhaetian fourth-order transgressive events. The unconformable base of the Hettangian fluvial sandstones (Boserup beds) of the Helsingborg Member is correlated with SB 9. The two Hettangian maximum flooding surfaces (MFS 9, MFS 10) are difficult to identify with confidence from the available descriptions but may be correlated with marine intervals at the Planorbis/Liasicus Zone boundary and in the Angulata Zone (Norling et al. 1993). Braided fluvial sandstones are recognised in the lowermost Sinemurian of the lower Döshult Formation in the Örby section (Erlström et al. 1999; locality 2), and the base of the sandstones which form the boundary to the paralic Helsingborg Member is here correlated with SB 11 in the Bucklandi Zone. The paralic flooding surface on top of the fluvial sandstones at Örby is correlated with TS 11 which was a very significant and rapid marine flooding event in the Bucklandi Zone that influenced the entire basin. The next sequence boundary in the Örby section which is overlain by a thin fluvial sandstone may correspond to a minor event of coastal progradation in the Fjerritslev Trough and at Stenlille probably occurring in the Semicostatum Zone (Fig. 31). The maximum flooding surface occurring in the Döshult Member, $5 \mathrm{~m}$ below the base of the Pankarp Member (Frandsen \& Surlyk 2003, this volume) is correlated with MFS 11, a correlation that is supported by the ostracod data. The boundary between the Döshult and Pankarp Members is interpreted as a sequence boundary by Frandsen \& Surlyk (2003, this volume) and is correlated with SB 12, based on the available biostratigraphy. A regressive event in the late Sinemurian is indicated by a sandstone layer with a coal bed in the Pankarp Member (Sivhed 1984; Norling et al. 1993); this event is not recognised in the deep basin. Sequence stratigraphic correlation with the remaining part of the marine succession, the Katslösa and Rydebäck Formations, is not yet possible. It is suggested, however, that the conglomeratic horizons indicating breaks in the marine Rydebäck Member (Norling et al. 1993) are likely candidates for sequence boundaries.

The Hettangian-Sinemurian Sose Bugt section of the Arnager-Sose Fault Block unconformably overlies Upper Triassic strata marking SB 1 of Surlyk et al. (1995), which is correlated with SB 9 of this study. Furthermore, the Lower Sinemurian SB 2 of Surlyk et al. (1995) is correlated with SB 11, and the Upper Sinemurian SB 4 with SB 12 (Fig. 31). The upper Hettangian SB 10 of this study is proposed to separate the lower Hettangian Munkerup Member from the upper Hettangian - Sinemurian Sose Bugt Member; the boundary between the two members is not known, however, due to lack of exposure. The questionable SB 3 recognised by Surlyk et al. (1995) at the base of some small channel units may correspond to the above-mentioned short-term event of coastal progradation in parts of the Danish area (Stenlille) and in the Fjerritslev Trough. MFS 10 and MFS 11 are correlated with thin shoreface sands representing marine incursions and MFS 12 is correlated with a $20 \mathrm{~cm}$ thick clay bed occurring just above SB 4 of Surlyk et al. (1995). SB 13 is assumed to occur in the marine shoreface sandstones of the Hasle Formation and may correlate to an erosion surface in the type section of the Hasle Formation separating sandstones with two 


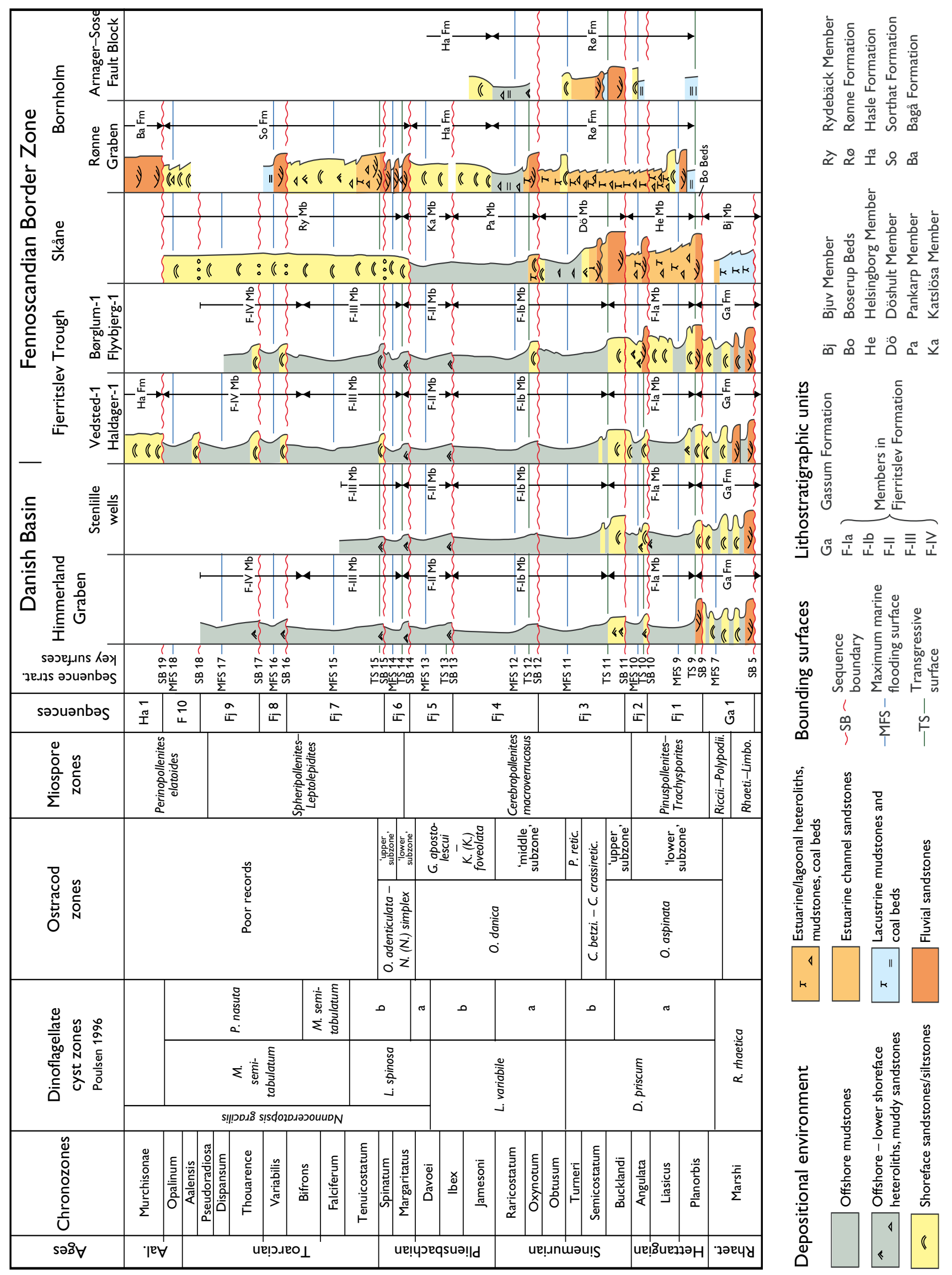


different diagenetic evolutionary trends (Larsen \& Friis 1991; Nielsen 1995); biostratigraphic evidence from ammonites seems to confirm this suggestion (Donovan \& Surlyk 2003, this volume). The base of the fluvial sand in the lower Sorthat Formation (Michelsen et al. 2003, this volume) is correlated with SB 14, and MFS 14 is correlated with a c. $2.1 \mathrm{~m}$ thick lagoonal unit with carbonaceous clay containing abundant dinoflagellates and a marine-influenced coal seam (Batten et al. 1994; Koppelhus \& Nielsen 1994; Nielsen 1995; Petersen \& Nielsen 1995). SB 15 occurs at the base of a $19 \mathrm{~m}$ thick fluvial-estuarine channel unit and MFS 15 is correlated with hummocky cross-stratified sands occurring in a lagoonal unit, based on the dinoflagellate biostratigraphy (Koppelhus \& Nielsen 1994). The base of a thin fluvial sand possibly correlates with SB 16. An upper Toarcian hiatus is suggested from the available biostratigraphy. The $4-5 \mathrm{~m}$ thick unit of transgressive shoreface sandstones that erosionally overlies lacustrine clays is correlated with the Early Aalenian MFS 18, and the base of the overlying coarse-grained pebbly alluvial sands is correlated with SB 19, which marks the significant change in deposition to continental Middle Jurassic.

\section{Synthesis of Upper Triassic - Jurassic basin evolution}

\section{Basin formation and structural development}

Late Carboniferous continental deposition preceded the rifting of the basin (Michelsen \& Nielsen 1991, 1993), which was presumably related to Late Carboniferous Early Permian plate reorganisations (Ziegler 1982; Vejbæk 1989, 1990). Regional crustal stretching and dextral strike-slip movements along the Tornquist Zone caused formation of extrusive and intrusive volcanic rocks,

\section{Facing page:}

Fig. 31. Chronostratigraphic scheme for the Danish Basin and the Fennoscandian Border Zone showing the Rhaetian (part) to Lower Aalenian sequence stratigraphic key surfaces, depositional environments, biozones and lithostratigraphy. The scheme compares the basinal successions of the deep Danish Basin with successions deposited along the basin margin in Skåne and on Bornholm during the Late Triassic - Early Jurassic period of relative tectonic tranquillity, widespread subsidence and maximum control by eustatic or regional sealevel changes. numerous tilted fault blocks composed of Lower Palaeozoic rocks and deposition of thick Lower Permian syn-rift prisms in the Danish Basin, the Fennoscandian Border Zone and the Oslo Graben (Vejbæk 1985, 1989, 1990; Liboriussen et al. 1987; Norling \& Bergström 1987; Ro et al. 1990; Michelsen \& Nielsen 1991, 1993; Mogensen 1994, 1996). The thick wedges in the hangingwall blocks comprise alluvial conglomerates and lacustrine mudstones with volcaniclastics eroded from footwall crests (Michelsen \& Nielsen 1991). Continued erosion caused deep truncation of the crests and formation of the regional mid-Permian unconformity that forms the base for the post-rift succession. Possible phase transformations in the deep crust and post-rift cooling caused rapid regional subsidence in Late Permian - Early Triassic times (Vejbæk 1989, 1990). The Danish Basin and parts of the Sorgenfrei-Tornquist Zone were transgressed in the Late Permian, and thick carbonate and salt deposits accumulated in the centre of the basin, whereas shallow marine and continental clastics were deposited along the basin margin in the Sorgenfrei-Tornquist Zone. During Early-Middle Triassic times, several thousands of metres of dominantly continental strata were deposited in a hot and arid climate (Bertelsen 1980). The Triassic transtensional strike-slip movements in the Sorgenfrei-Tornquist Zone continued into the Early Jurassic causing subsidence of the Himmerland Graben, the Fjerritslev Trough, the Rønne Graben and parts of Skåne (Rolle et al. 1979; Gravesen et al. 1982; Vejbæk 1985, 1990; Liboriussen et al. 1987; Norling \& Bergström 1987; Erlström et al. 1997). Minor down-to-basin fault displacements occurred locally along the southern basin margin. The thermal subsidence continued into Late Triassic - Early Jurassic times, and most of the basin experienced relatively uniform subsidence until the Early Aalenian uplift completely changed the configuration of the basin.

\section{Late Triassic marine flooding}

A gradual change from arid towards more humid conditions took place in the Late Triassic, partly due to formation of a large epicontinental sea (Bertelsen 1978, 1980; Parrish et al. 1982; Ziegler 1982; Hallam 1984, 1985; Batten et al. 1994; Scotese 1994). Carnian deposition of lacustrine and sabkha mudstones was terminated by the Early Norian marine transgression that probably came from the south. The transgression led to deposition of oolitic limestones succeeded by marlstones and fossiliferous claystones of the Vinding 
Formation, 40-100 m thick (Bertelsen 1978, 1980; L.H. Nielsen, L. Hamberg and E.B. Koppelhus in: Nielsen 1995). At its maximum late Norian extent, the shallow sea covered most of the Danish Basin, the RingkøbingFyn High and the North German Basin. At the same time, fluvial arkosic sands and lacustrine muds were deposited in the Sorgenfrei-Tornquist Zone, Skåne, Rønne Graben and along the northern basin margin. These deposits are included in the Skagerrak and Kågeröd Formations (Bertelsen 1980; Gravesen et al. 1982; Sivhed 1984; Ahlberg 1994; Nielsen 1995).

After the maximum transgression, a phased regression followed, and shoreface and fluvial sands of the lower Gassum Formation were deposited in stepwise more basinwards positions intercalated with clays of the upper Vinding Formation in the basin centre. In the Fjerritslev Trough, alternating units of arkosic fluvial sand and lacustrine mud of the Skagerrak Formation were deposited, reflecting repeated base-level changes controlled by the short-term sea-level fluctuations. The regression culminated in the early Rhaetian with the formation of an extensive, fluvially-incised sequence boundary (SB 5; Figs 26, 31). At this time, the Ringkøbing-Fyn High was exposed to erosion and fine-grained sand was shed to the basin from the high. Non-deposition or erosion probably occurred on the Skagerrak-Kattegat Platform, in Skåne and on Bornholm, east of the Rønne Graben. When sea-level slowly rose again, fluvial-estuarine deposits, up to $30 \mathrm{~m}$ thick, were deposited above the sequence boundary before widespread flooding occurred. The transgression continued but was punctuated by two short-term, forced regressions that led to deposition of widespread shoreface sand sheets encased in transgressive offshore mud. The transgression accelerated and reached its maximum in the latest Rhaetian, when the Danish Basin, the Sorgenfrei-Tornquist Zone, the Skagerrak-Kattegat Platform, the North German Basin, and the Ringkøbing-Fyn High were covered by the sea (MFS 7, Figs 26, 31). The aggrading floodplain succession in Skåne with the Rhaetian coal seams A and B shows weak marine influence (Vallåkra and Bjuv Members; Troedsson 1948, 1951; Lund 1977; Sivhed 1984; Norling et al. 1993; Ahlberg \& Arndorff 1994) and was probably deposited during this transgressive phase (Fig. 31). The increasing amount of macroplant fossils, rootlets, coal seams and more mature sandstones indicates that the climate became more humid during the Late Rhaetian transgressive phase.

\section{Latest Rhaetian - earliest Hettangian regression}

An overall sea-level fall commenced after the maximum transgression, and two phases of coastal progradation, at the Rhaetian-Hettangian boundary and in the earliest Hettangian, caused deposition of two thin regressive shoreface sand sheets that constitute the upper part of the Gassum Formation over much of the Danish Basin. The regression culminated with coastal progradation far into the basin accompanied by fluvial erosion and incision in the Himmerland Graben, the Fjerritslev Trough and along the southern basin margin, where parts of the Ringkøbing-Fyn High were exposed and supplied sand to the basin (SB 9; Fig. 31). At the same time, Rhaetian or older rocks were eroded in Skåne, Poland, North Germany, England and on Bornholm; the resultant widespread sequence boundary marking a late Rhaetian hiatus is onlapped by transgressive Lower Jurassic deposits. Thus, the relatively conformable Upper Triassic - lowermost Jurassic succession in the Danish Basin reflects a more rapidly fluctuating sea level than typically recognised (Hallam 1988, 1997) with maxima in late Norian and latest Rhaetian times and lows in the early Rhaetian and the earliest Hettangian.

\section{Early Jurassic basin expansion}

A subtropical to warm-temperate and humid climate characterised the Jurassic period, and large quantities of clay were supplied to the basin from the weathering of Palaeozoic shales, granitic basement of the Baltic Shield and a possible Carboniferous regolith (Ziegler 1982; Pedersen 1983; Schmidt 1985; Norling \& Bergström 1987; Nielsen \& Koppelhus 1991; Surlyk et al. 1995). The basin expanded north-eastwards against the Baltic Shield during Early Jurassic time owing to the combined effects of eustatic sea-level rise, regional subsidence and local block-faulting caused by transtensional strike-slip movements in the Sorgenfrei-Tornquist Zone (Rolle et al. 1979; Gravesen et al. 1982; Norling \& Bergström 1987; Nielsen 1995; Surlyk et al. 1995; Mogensen 1996).

\section{Hettangian - Early Pliensbachian transgression}

In the Danish and North German Basins, the transgression commenced in the early Hettangian Planorbis 
Zone. Fully marine mudstones belonging to the F-Ia unit of the Fjerritslev Formation overlie the sandy Gassum Formation in most of the Danish Basin (Fig. 31). The mudstones have a low content of ostracods, foraminifera and infaunal bivalves, but the high content of landderived organic matter suggests a relatively high rate of deposition. In the north-eastern part of the Sorgenfrei-Tornquist Zone, aggrading parasequences of fluvial and shoreface sands with subordinate offshore muds were deposited, while lagoonal parasequences were formed on the Skagerrak-Kattegat Platform. The transgression peaked in the early and late Hettangian, interrupted by a short-term regression in the middle Hettangian (SB 10; Fig. 31).

The depositional area also expanded in the southeasternmost part of the basin on Bornholm. In the Rønne Graben, lacustrine conditions in the early Hettangian were followed by deposition of dominantly coastal plain deposits, up to $200 \mathrm{~m}$ thick. Onshore Bornholm, lacustrine mudstones overstepped small fault blocks (Gravesen et al. 1982). The basin expansion is also evident in Skåne, Poland and Germany, where basal Hettangian fluvial deposits are overlain by thick coastal plain, deltaic and shallow marine deposits, locally up to $400 \mathrm{~m}$ thick (Troedsson 1951; Norling 1972; Lund 1977; Sivhed 1984; Pieńkowski 1991; Ahlberg 1994; Ahlberg \& Arndorff 1994; Feldman-Olszewska 1997a; Ahlberg et al. 2003, this volume).

The large increase in accommodation space governing deposition of transgressive paralic deposits along the basin margin was interrupted briefly by a fall in sea level, soon after the Hettangian-Sinemurian boundary. This resulted in fluvial incision on the Skagerrak-Kattegat Platform and on Bornholm and deposition of braided fluvial sandstones in Skåne (basal Döshult Member), while regressive shoreface sand was deposited in the Fjerritslev Trough (SB 11; Fig. 31). Farther basinward, heteroliths and silty mudstones were deposited above the conformable part of the sequence boundary. A rapid sea-level rise followed in the earliest Sinemurian (upper part of the Bucklandi Zone) and transgressive marine muds of the F-Ib unit finally overstepped fluvial and marine sands of the Gassum Formation in the Sorgenfrei-Tornquist Zone and on the Skagerrak-Kattegat Platform. In the basin, up to $150 \mathrm{~m}$ of uniform mudstones were deposited, showing a marked thinning towards the north-eastern basin margin. The corresponding deposits in the Rønne Graben consist of c. 130 m of aggrading lagoonal parasequences with a marine shoreface unit marking the culmination of the transgression (MFS 11; Fig. 31; Nielsen 1995). On the shallow Arnager-Sose
Fault Block, the culmination is recorded by a thin shoreface sandstone. In Skåne, fluvial, estuarine and shallow marine sands and muds of the Döshult Member were deposited followed by marine clays of the Pankarp Member (Norling 1972; Sivhed 1980, 1984; Norling et al. 1993; Erlström et al. 1999; Frandsen \& Surlyk 2003, this volume). In the Late Sinemurian, a minor sea-level fall caused a slight basinwards progradation of coastal parasequences on the Skagerrak-Kattegat Platform and in parts of the Sorgenfrei-Tornquist Zone. After this minor excursion, the overall Early Jurassic sea-level rise continued, and reached a maximum in the latest Sinemurian, possibly close to the Oxynotum-Raricostatum Zone boundary. In the centre of the Danish Basin, the diversity and abundance of the ostracod fauna decreased and infaunal bivalves and some of the epifaunal bivalves disappeared due to reduced oxygenation (Pedersen 1986; Michelsen 1989b). In the Rønne Graben, lagoonal and lacustrine parasequences with minor fluvial sand continued to aggrade (amounting to $c .200 \mathrm{~m}$ ) until sea-level rise outpaced the rate of paralic sedimentation (Nielsen 1995). Restricted offshore mud was deposited on the southern part of the Rønne-Hasle Fault Block and on the Arnager-Sose Fault Block during the maximum phase of transgression (Nielsen 1995; Surlyk et al. 1995). A gradual decrease in the rate of sea-level rise in the Early Pliensbachian Jamesoni Zone caused the formation of thick, aggrading to weakly forestepping shallow marine parasequences on the Arnager-Sose and RønneHasle Fault Blocks (the lower Hasle Formation), and on the Skagerrak-Kattegat Platform, where a distinct basinwards progradation of shoreface sandstones is seen (Fig. 25). The coastal sandstones capped by a coal bed of the upper Pankarp Member in Skåne (Sivhed 1984; Frandsen \& Surlyk 2003, this volume) seem to represent a local regression based on the available biostratigraphic data.

The regression culminated in the middle Early Pliensbachian (early Ibex Zone); in the Danish Basin, deposition changed from fine-grained mud (F-Ib unit) to silty and sandy heteroliths (F-IIa beds, SB 13; Fig. 31). In Skåne, a distal sequence boundary was developed within marine mudstones separating the Pankarp Member from the overlying Döshult Member (Frandsen \& Surlyk 2003, this volume). On the Skagerrak-Kattegat Platform and on Bornholm, deposition of shallow marine shoreface sand ceased for some time due to submarine or subaerial erosion and bypass. When the sea level started to rise again, deposition of fine-grained mud resumed in the Danish Basin (lower part of F-IIb beds), while shoreface sand again was deposited on Bornholm 
(upper Hasle Formation). Backstepping parasequences of marine sand were succeeded by transgressive mud on the Skagerrak-Kattegat Platform. Peak transgression was reached in the late Early Pliensbachian Davoei Zone. Thereafter, the rate of sea-level rise decreased and a coarsening-upwards succession of mud and finegrained heteroliths was deposited in the Danish Basin (middle part of F-IIb), while deposition of regressive marine sands occurred on Bornholm.

\section{Late Pliensbachian - Early Aalenian sea-level fluctuations}

Significant erosion took place on the Skagerrak-Kattegat Platform during a sea-level fall in the early Late Pliensbachian Margaritatus Zone (SB 14; Figs 25, 31). Basinwards, in the Fjerritslev Trough and the Danish Basin, deposition changed to silty and sandy mud and finegrained sand, showing very marked thinning over salt structures possibly reflecting shallow water depths (upper part of F-IIb and F-IIc beds). At the basin margin, deposition of regressive shallow marine sands continued in Skåne (Rydebäck Member), while marine deposition ceased in the Rønne Graben (Nielsen 1995).

The ensuing sea-level rise, which initiated the second Early Jurassic transgression, commenced in the Margaritatus Zone and reached a peak in the late Late Pliensbachian (early Spinatum Zone). Marine silty mud was deposited in the Danish Basin, while marine sand with bivalves was deposited in the Fjerritslev Trough. Deposits from this period are absent on the Skagerrak-Kattegat Platform due to bypass or later erosion. On Bornholm, the sealevel rise created accommodation for the accumulation of 100-140 m of coarse-grained fluvial sands, floodplain deposits, peats and lagoon-fill deposits referred to the new Sorthat Formation (Fig. 31; Koppelhus \& Nielsen 1994; Nielsen 1995; Petersen \& Nielsen 1995; Michelsen et al. 2003, this volume).

The following sea-level fall culminated in the late Spinatum Zone with the formation of a widespread regressive surface of marine erosion and progradation of a sandy shoreface into the central parts of the Fjerritslev Trough (SB 15; Fig. 31). The sea-level fall caused erosion of Lower Pliensbachian strata on the Skagerrak-Kattegat Platform, and incision on Bornholm. The ensuing sea-level rise caused marine flooding over the entire basin at the Pliensbachian-Toarcian boundary, including the Sorgenfrei-Tornquist Zone and the Skagerrak-Kattegat Platform, and deposition of transgressive marine mud commenced. Lagoonal sand and mud and restricted marine shoreface sand were deposited on Bornholm (upper Sorthat Formation; Koppelhus \& Nielsen 1994). The transgression reached its maximum in the Early Toarcian Falciferum Zone (MFS 15). Due to oxygen-poor conditions, the ostracod fauna disappeared and an increasing amount of amorphous marine matter is preserved making the deposits a favourable source rock for hydrocarbons (Thomsen et al. 1987; Michelsen 1989b; Dybkjær 1991). During the remainder of the Early Jurassic and in the Early Aalenian Opalinum Zone, a succession of up to $150 \mathrm{~m}$ of marine mudstones with three shoreface sandstones was deposited in the Sorgenfrei-Tornquist Zone; the shoreface sandstones overlie regressive surfaces of marine erosion and accumulated during sea-level falls. On the Skagerrak-Kattegat Platform, where accommodation was much less, thin peat-bearing lagoonal successions were deposited on the subaerial erosion surfaces during ensuing transgressions. The basin gradually shrank and became isolated from the North Sea Basin due to initial uplift, and a poor circulation pattern and possibly brackish conditions at the margin caused impoverishment of the fauna. In Skåne, regressive, shallow marine sand of the Rydebäck Member was deposited, while erosion probably prevailed during much of late Early - Late Toarcian time on Bornholm (Nielsen 1995).

\section{Late Early - Middle Jurassic uplift and erosion}

The Ringkøbing-Fyn High and most of the Danish Basin were uplifted in late Early Jurassic - early Middle Jurassic times, and the Triassic - Lower Jurassic successions were eroded on the highest parts of the Ringkøbing-Fyn High. The Lower Jurassic was deeply eroded in the uplifted area north of the high, whereas erosion did not reach such deep levels closer to the Sorgenfrei-Tornquist Zone. In the fault-bounded Sorgenfrei-Tornquist Zone, where subsidence still occurred but at a much lower rate than before, the change in basin configuration resulted in a shift from deposition of homogeneous offshore muds to shallow marine sands. The sandstones overlie a forced regressive surface of marine erosion dated to the top of the Lower Aalenian Opalinum Zone, and are thus contemporaneous with the greatest basin shift in facies recorded from the Lower-Middle Jurassic in the North Sea basins. In Skåne, uplift was accompanied by faulting, erosion and volcanism. Hence, during the rest of the Aalenian, the Bajocian and the early Bathonian, deposition was more or less confined to the narrow zone bounded by the Fjerritslev and Børglum 
Faults and their south-eastwards continuation in Kattegat, Øresund and Skåne. Material was supplied from both the uplifted areas to the west and south-west, and from the Baltic Shield. From the Fjerritslev Trough in the north-west to Skåne in the south-east, shallow marine, paralic and fluvial sediments were deposited, making up the Haldager Sand Formation, the Vilhelmsfält Formation and the Mariedal formation. In the Rønne Graben, lacustrine muds, peats and alluvial sands of the Bagå Formation were deposited. The general scarcity of marine fossils and pronounced reworking of palynomorphs hinder precise dating of the deposits, and large parts of the Aalenian-Callovian time interval are probably not represented in the Sorgenfrei-Tornquist Zone because of insufficient accommodation space and erosion during formation of sequence boundaries and ravinement surfaces.

\section{Late Middle - Late Jurassic basin expansion}

The area of subsidence gradually expanded in Bathonian-Volgian times with deposition of Bathonian(?) braided fluvial sands on the Skagerrak-Kattegat Platform and south-west of the Fjerritslev Trough in the Himmerland Graben. A marine transgression close to the Callovian-Oxfordian boundary influenced most of the basin and accommodation space was also created in the former by-pass zone of the southern part of the basin and on the Skagerrak-Kattegat Platform, where fluvial sands were now deposited. During the Oxfordian, the sedimentation area was further enlarged and a northeastwards thickening wedge of transgressive, fossiliferous marine sand and mud was deposited above lagoonal deposits on the Skagerrak-Kattegat Platform. Lagoonal deposition apparently still dominated to the south-west (Flyvbjerg Formation), where the structural high was still present, albeit with much reduced relief. A latest Oxfordian sea-level fall resulted in coastal progradation on the Skagerrak-Kattegat Platform and in the Fjerritslev Trough; fluvial and shallow marine sands were deposited, and a south-west prograding wedge was formed. Extensive marine flooding occurred in the Kimmeridgian, and sedimentation of marine mud (Børglum Formation) characterised the whole area, although the marked thinning towards the south-west emphasises the reduced accommodation here. During Volgian-Ryazanian times, the depositional environment was dominantly a shallow shelf with three-four major phases of coastal progradation (sequences Fr 1, Fr 2, Fr 3; Fig. 26). Coastal and deltaic sandy deposits (Frederikshavn Formation) accu- mulated on the Skagerrak-Kattegat Platform and in parts of the Sorgenfrei-Tornquist Zone, while marine muds were deposited over much of the basin. The occurrence of sandy beds in the south-westernmost parts of the basin indicates that during low sea level, the Ringkøbing-Fyn High still supplied some sand. Ammonites indicating the Middle Volgian Albani Zone (Birkelund \& Pedersen 1980) are found in sequence Fr 1, and dinocysts indicating the Jurassic-Cretaceous boundary (Davey 1982) occur in sequence Fr 2 close to the maximum flooding surface. On the Bornholm High to the east, fluvial deposition followed by paralic deposition was resumed above a Callovian-Kimmeridgian unconformity due to the Late Volgian - Ryazanian sea-level rise.

\section{Conclusions}

The depositional area covering the Danish Basin and the Fennoscandian Border Zone underwent great changes in Late Triassic - Jurassic times in terms of tectonics, areal extent, sea level and climate, and these factors governed important differences in the depositional style of the Upper Triassic - Jurassic sequences.

A shallow, low-gradient marine embayment without a shelf-slope break was established in the Danish Basin and parts of the Fennoscandian Border Zone in Late Triassic time. Due to the gentle basin physiography, fourth-order sea-level changes exerted a strong control on the distribution and architecture of the depositional facies. Extensive coastal progradation occurred during sea-level fall, and regressive shoreface sandstones were deposited over large areas, resting on regressive surfaces of marine erosion. Subsequent sea-level rises caused widespread flooding and the formation of ravinement surfaces overlain by marine mudstones. The changes in stacking pattern from forestepping to backstepping and vice versa occur at a pronounced, third-order fluvial incision surface with thick estuarine valley-fill deposits, and at a widespread marine maximum flooding surface, respectively. The extensive fourth-order shoreface sandstone sheets and associated paralic deposits were developed because the shallow basin was influenced by rapid, low-amplitude sea-level fluctuations, a high, continuous sediment influx from the basin margins on three sides, and a high, longshore sediment distribution rate. Fluvial transport of sand into the basin was effective, probably because of relatively poorly developed vegetation.

A deeper and fully marine, low-gradient shelf was established in Early Jurassic time due to steady subsidence 
and overall eustatic/regional sea-level rise. The Ringkøbing-Fyn High was permanently flooded, and the basin was primarily sourced with mud at a high continuous rate from landmasses to the east and north exposed to extensive weathering in the humid, warm-temperate to subtropical climate. At this time, vegetation was widespread and well-established. Sedimentation kept pace with the steady formation of new accommodation space, and biozones and facies packages are thickly developed; omission surfaces and condensed sections are poorly developed. Storm-generated seawards flowing currents carried mud in suspension into the basin, where it was deposited below average storm wave base. Local topography was smoothed out by draping mud, forming widespread uniform and thick packages of mudstones with a conformable stratal pattern. Minor sea-level fluctuations left only insignificant traces compared to the Upper Triassic because of the relatively deep depositional basin. Only when larger eustatic falls exceeded subsidence and wave-base was significantly lowered were coarse-grained mudstones and fine-grained heteroliths deposited above regressive, marine surfaces; these deposits form thin lowstand systems tracts overlying conformable sequence boundaries. Coastal sand was mainly trapped at the basin margin and subaerial exposure was very limited within the study area.

The sea-level curve from the Danish Basin parallels the trend of other Early Jurassic sea-level curves and shows great similarities in detail, testifying to the eustatic or large-scale regional influence of sea level on the depositional pattern.

The regime of tectonic tranquillity that characterised most of the basin during the Late Triassic - Early Jurassic was replaced by one of uplift of most of the basin in Middle Jurassic time. It began with a reduction of the depositional area and the development of a restricted marine environment in the Late Toarcian, and culminated with the formation of a regional intra-Aalenian unconformity, the most significant unconformity of the Upper Triassic - Jurassic succession. Deposition in Late Aalenian - Bajocian times became confined to the faultbounded Sorgenfrei-Tornquist Zone, where subsidence still occurred, albeit at a much reduced rate. The preserved sequences consist primarily of fluvial-estuarine and lagoonal deposits of late lowstand to early transgressive systems tracts, while late transgressive and highstand systems tracts are almost absent, due to cannibalisation during sea-level falls owing to the very slow subsidence rate. During the Late Jurassic, subsidence accelerated and the depositional area gradually increased in size and depth, although the Ringkøbing-
Fyn High functioned as a low-relief paralic hinterland that still supplied small amounts of sand to the basin until the Ryazanian.

The uplift of the Ringkøbing-Fyn High and its flanks including most of the Danish Basin occurred contemporaneously with uplift in the central North Sea. The intra-Aalenian unconformity shows progressively deeper truncation against the high and progressively younger strata onlap the unconformity in the same direction, similar to the pattern shown by the 'mid-Cimmerian Unconformity' in the North Sea against the dome centre. The similarity in age and geometric configuration points to a common causal mechanism for the formation of these unconformities. The subcrop and onlap contour patterns of the unconformity parallel the Ringkøbing-Fyn High and are not compatible with the postulated semi-circular subcrop stratigraphy of the North Sea unconformity that has been used as an argument for a mantle plume causing domal uplift. The uplifted area rather takes the form of a broad irregular shaped arch. The contour pattern in the Danish Basin, the occurrence of several volcanic centres in the North Sea and the presence of Middle Jurassic basalts in southern Sweden indicate that an interpretation of the regional uplift should consider a more complex plume pattern, in addition to the response of the Ringkøbing-Fyn High and the role of the deep, fundamental Sorgenfrei-Tornquist fracture zone.

\section{Acknowledgements}

The paper is based on a Ph.D. study at the University of Copenhagen supervised by Finn Surlyk and Olaf Michelsen. The supervisors, colleagues at GEUS (Jan Andsbjerg, Torben Bidstrup, Karen Dybkjær, Peter Japsen, Peter N. Johannessen, Jon R. Ineson, Anders Mathiesen, Niels E. Poulsen, Ole V. Vejbæk), Lars Hamberg (DONG) and Eva B. Koppelhus are thanked for stimulating discussions. The study was financially supported by GEUS and the Danish Research Academy. The reviews of Stephen Hesselbo, Jon R. Ineson and Gunver K. Pedersen are highly appreciated. 


\section{References}

Ahlberg, A. 1994: Facies analysis of alluvial and deltaic environments in the Hettangian of NW Skåne, southern Sweden, 18 pp. In: Ahlberg, A.: Deposition and diagenesis of the RhaetianHettangian succession (Triassic-Jurassic) in southern Sweden: a synthesis. Lund Publications in Geology 123.

Ahlberg, A. \& Arndorff, L. 1994: Pedogenesis and sedimentology of alluvial Upper Triassic (Middle Rhaetian) strata of the Bjuv Member (Höganäs Formation), southern Sweden, 17 pp. In: Ahlberg, A.: Deposition and diagenesis of the RhaetianHettangian succession (Triassic-Jurassic) in southern Sweden: a synthesis. Lund Publications in Geology 123.

Ahlberg, A., Sivhed, U. \& Erlström, M. 2003: The Jurassic of Skåne, southern Sweden. In: Ineson, J.R. \& Surlyk, F. (eds): The Jurassic of Denmark and Greenland. Geological Survey of Denmark and Greenland Bulletin 1, 527-541 (this volume).

Ainsworth, R.B. \& Pattison, S.A.J. 1994: Where have all the lowstands gone? Evidence for attached lowstand systems tracts in the Western Interior of North America. Geology 22, 425-418.

Allen, G.P. \& Posamentier, H.W. 1994: Transgressive facies and sequence architecture in mixed tide- and wave-dominated incised valleys: examples from the Gironde estuary, France. In: Dalrymple, R.W., Boyd, R. \& Zaitlin, B.A. (eds): Incised-valley systems: origin and sedimentary sequences, SEPM (Society for Sedimentary Geology) Special Publication 51, 225-240.

Allen, J.R.L. 1965: Fining-upwards cycles in alluvial successions. Journal of Geology 4, 229-246.

Allen, J.R.L. 1984: Sedimentary structures: their character and physical basis 1, 2, 593 pp., 663 pp. Developments in Sedimentology 30A, B. Amsterdam: Elsevier Scientific Publishing Company.

Baartman, J.C. \& Christensen, O.B. 1975: Contributions to the interpretation of the Fennoscandian Border Zone. Danmarks Geologiske Undersøgelse II. Række 102, 47 pp.

Badley, M.E., Price, J.D., Dahl, C.R. \& Agdestein, T. 1988: The structural evolution of the northern Viking Graben and its bearing upon extensional modes of basin formation. Journal of the Geological Society (London) 145, 455-472.

Banerjee, I. 1989: Tidal structures in the Glauconitic Sandstone, Countess Field, southern Alberta, Canada. In: Reinson, G.E. (ed.): Modern and ancient examples of clastic tidal deposits a core and peel workshop, 89-97. Second International Research Symposium on Clastic Tidal Deposits, Calgary, Alberta, 22-25 August, 1989. Calgary: Canadian Society of Petroleum Geologists.

Barr, D. 1987: Lithospheric stretching, detached normal faulting and footwall uplift. In: Coward, M.P., Dewey, J.F. \& Hancock, P.L. (eds): Continental extensional tectonics. Geological Society Special Publication (London) 28, 75-94.

Barwis, J.H. 1978: Sedimentology of some South Carolina tidalcreek point bars, and a comparison with their fluvial counterparts. In: Miall, A.D. (ed.): Fluvial sedimentology. Canadian Society of Petroleum Geologists Memoir 5, 129-160.

Batten, D.J., Koppelhus, E.B. \& Nielsen, L.H. 1994: Uppermost Triassic to Middle Jurassic palynofacies and palynomiscellanea in the Danish Basin and Fennoscandian Border Zone. Cahiers de Micropaléontologie 9, 21-45.
Bergström, J. 1984: Lateral movements in the Tornquist Zone. Geologiska Föreningens i Stockholm Förhandlingar 106, 379-380.

Bergström, J., Holland, B., Larsson, K., Norling, E. \& Sivhed, U. 1982: Guide to excursions in Scania. Sveriges Geologiska Undersökning Serie Ca 54, 95 pp.

Bertelsen, F. 1978: The Upper Triassic - Lower Jurassic Vinding and Gassum Formations of the Norwegian-Danish Basin. Danmarks Geologiske Undersøgelse Serie B 3, 26 pp.

Bertelsen, F. 1980: Lithostratigraphy and depositional history of the Danish Triassic. Danmarks Geologiske Undersøgelse Serie B 4, 59 pp.

Bertelsen, F. \& Michelsen, O. 1970: Megaspores and ostracods from the Rhaeto-Liassic section in the boring Rødby No. 1, southern Denmark. Danmarks Geologiske Undersøgelse II. Række 94, 60 pp.

Birkelund, T. \& Pedersen, G.K. 1980: Middle Volgian ammonites and trace fossils from the Frederikshavn Member of the Bream Formation, northern Jutland. Danmarks Geologiske Undersøgelse Årbog 1979, 95-104.

Bloos, G. 1990: Sea-level changes in the Upper Keuper and in the Lower Lias of Central Europe. Cahiers de l'Institut Catholique Lyon Serie Scientifique 3, 5-16.

Boersma, J.R. \& Terwindt, J.H.J. 1981: Berms on an intertidal shoal: shape and internal structure. In: Nio, S.-D., Shüttenhelm, R.T.E. \& van Weering, T.C.E. (eds): Holocene marine sedimentation in the North Sea Basin. International Association of Sedimentologists Special Publication 5, 39-49.

Britze, P. \& Japsen, P. 1991: Geological map of Denmark, 1:400 000. The Danish Basin. 'Top Zechstein' and the Triassic. Danmarks Geologiske Undersøgelse Kortserie 31.

Bylund, G. \& Halvorsen, E. 1993: Palaeomagnetic study of Mesozoic basalts from Scania, southernmost Sweden. Geophysical Journal International 114, 138-144.

Callomon, J.H. 1984: Biostratigraphy, chronostratigraphy and all that - again! In: Michelsen, O. \& Zeiss, A. (eds): International Symposium on Jurassic stratigraphy (Erlangen 1984) 3, 611-624. Copenhagen: Geological Survey of Denmark.

Cant, D.J. \& Walker, R.G. 1978: Fluvial processes and facies sequences in the sandy braided South Saskatchewan River, Canada. Sedimentology 25, 625-648.

Christensen, J.E. \& Korstgård, J.A. 1994: The Fjerritslev Fault offshore Denmark - salt and fault interactions. First Break 12, $31-42$.

Christensen, O.B. 1971: Den stratigrafiske inddeling af præ-zechstein aflejringerne i Rønde nr. 1. In: Rasmussen, L.B. (ed.) Dybdeboringen Rønde nr. 1 på Djursland. Danmarks Geologiske Undersøgelse III. Række 39, 119-123.

Christensen, O.B. 1972: Det danske sænkningsområdes udvikling i det mellemste Mesozoikum. Dansk Geologisk Forening Årsskrift for 1971, 55-62.

Christensen, O.B. 1973: Rønde og Nøvling formationerne (silur) i Nøvling nr. 1 (3534-3762 m). In: Rasmussen, L.B. (ed.): Dybdeboringen Nøvling nr. 1 i Midtjylland. Danmarks Geologiske Undersøgelse III. Række 40, 150-157.

Church, J.W., Davey, R.S., Merker, A.M., Robertson, A.G. \& Tooby, K.M. 1986: DOPAS Sæby 5710/22-1 onshore Denmark well: 
biostratigraphy of the interval 220-1854 m T.D., 62 pp. Robertson Research International Limited, Llandudno, UK.

Clifton, H.E. 1969: Beach lamination - nature and origin. Marine Geology 7, 553-559.

Clifton, H.E., Hunter, R.E. \& Phillips, R.L. 1971: Depositional structures and processes in the non-barred high-energy nearshore. Journal of Sedimentary Petrology 41, 651-670.

Cloetingh, S. 1988: Intraplate stresses: a tectonic cause for thirdorder cycles in apparent sea level? In: Wilgus, C.K. et al. (eds): Sea-level changes - an integrated approach. Society of Economic Paleontologists and Mineralogists Special Publication 42, 19-29.

Dadlez, R. 1976: Lower Jurassic. In: Sokolowski, S. (ed.): Geology of Poland 1(2), 156-163, 199-241. Warszaw: Wydawnictwa Geologiczne.

Dalrymple, R.W., Boyd, R. \& Zaitlin, B.A. 1994: History of research, types and internal organisation of incised-valley systems: introduction to the volume. In: Dalrymple, R.W., Boyd, R. \& Zaitlin, B.A. (eds): Incised-valley systems: origin and sedimentary sequences, SEPM (Society for Sedimentary Geology) Special Publication 51, 3-10.

Davey, R.J. 1982: Dinocyst stratigraphy of the latest Jurassic to Early Cretaceous of the Haldager No. 1 borehole, Denmark. Danmarks Geologiske Undersøgelse Serie B 6, 57 pp.

Davidson-Arnott, R.G.D. \& Greenwood, B. 1976: Facies relationships on a barred coast, Kouchibouguac Bay, New Brunswick, Canada. In: Davis, R.A. \& Ethington, R.L. (eds): Beach and nearshore sedimentation. Society of Economic Paleontologists and Mineralogists Special Publication 24, 149-168.

de Raaf, J.F.M., Boersma, J.R. \& van Gelder, A. 1977: Wave-generated structures and sequences from a shallow marine succession, Lower Carboniferous, County Cork, Ireland. Sedimentology 24, 451-483.

Donovan, D.T. \& Surlyk, F. 2003: Lower Jurassic (Pliensbachian) ammonites from Bornholm, Baltic Sea, Denmark. In: Ineson, J.R. \& Surlyk, F. (eds): The Jurassic of Denmark and Greenland. Geological Survey of Denmark and Greenland Bulletin 1, 555-583 (this volume).

Dott, R.H. \& Bourgeois, J. 1982: Hummocky stratification: significance of its variable bedding sequences. Geological Society of America Bulletin 93, 663-680.

Dybkjær, K. 1988: Palynological zonation and stratigraphy of the Jurassic section in the Gassum No. 1-borehole, Denmark. Danmarks Geologiske Undersøgelse Serie A 21, 73 pp.

Dybkjær, K. 1991: Palynological zonation and palynofacies investigation of the Fjerritslev Formation (Lower Jurassic - basal Middle Jurassic) in the Danish Subbasin. Danmarks Geologiske Undersøgelse Serie A 30, 150 pp.

Erlström, M. \& Guy-Ohlson, D. 1999: An Upper Triassic, Norian-Rhaetian, outlier in Skåne, southern Sweden. Bulletin of the Geological Society of Denmark 45, 89-97.

Erlström, M., Thomas, S.A., Deeks, N. \& Sivhed, U. 1997: Structure and tectonic evolution of the Tornquist Zone and adjacent sedimentary basins in Scania and the southern Baltic Sea area. Tectonophysics 271, 191-215.

Erlström, M., Sivhed U. \& Surlyk, F. 1999: A backstepping fluviatile-paralic-marine succession, Sinemurian, Lower Jurassic, Skåne, southern Sweden. Bulletin of the Geological Society of Denmark 46, 1-12.
EUGENO-S Working Group 1988: Crustal structure and tectonic evolution of the transition between the Baltic Shield and the North German Caledonides (the EUGENO-S Project). Tectonophysics 150, 253-348.

Everts, C.H. 1987: Continental shelf evolution in response to a rise in sea level. In: Nummedal, D., Pilkey, O.H. \& Howard, J.D. (eds): Sea-level fluctuation and coastal evolution. Society of Economic Paleontologists and Mineralogists Special Publication 41, 49-57.

Eynon, G. 1981: Basin development and sedimentation in the Middle Jurassic of the northern North Sea. In: Illing, L.V. \& Hobson, G.D. (eds): Petroleum geology of the continental shelf of North-West Europe: proceedings of the 2nd conference, 196-204. London: Heyden \& Son Ltd.

Fazekas, J.E. 1948: Weekly report (July 2nd - July 9th). In: Gassum-1 completion report. Unpublished report, Danish American Prospecting Company, Viborg, Denmark. Compiled (1993) by the Geological Survey of Denmark; Geological Survey of Denmark and Greenland archive file number 4518. Non-paginated.

Feldman-Olszewska, A. 1997a: Depositional systems and cyclicity in the intracratonic Early Jurassic basin in Poland. Kwartalnik Geologiczny 41, 475-490.

Feldman-Olszewska, A. 1997b: Depositional architecture of the Polish epicontinental Middle Jurassic basin. Kwartalnik Geologiczny 41, 491-508

Forbes, G.A., Rasul, S., Smout, R., King, A.D., Jacovides, J. \& Canham, A. 1985: Well 5611/23-1 and sidetrack, stratigraphical/paleontological final report (interval 120-3361 m), 76 pp. Unpublished report, Palaeoservices Ltd, England.

Frandsen, N. \& Surlyk, F. 2003: An offshore transgressive-regressive mudstone-dominated succession from the Sinemurian of Skåne, Sweden. In: Ineson, J.R. \& Surlyk, F. (eds): The Jurassic of Denmark and Greenland. Geological Survey of Denmark and Greenland Bulletin 1, 543-554 (this volume).

Fredbold, H. 1948: Notes on the stratigraphy of the lowermost part of the Lias and of the Upper Rhaetian in Gassum-1. In: Gassum-1 completion report. Unpublished report, Danish American Prospecting Company, Viborg, Denmark. Compiled (1993) by the Geological Survey of Denmark; Geological Survey of Denmark and Greenland archive file number 4518. Non-paginated.

Gradstein, F.M., Agterberg, F.P., Ogg, J.G., Hardenbol, J., van Veen, P., Thierry, J. \& Huang, Z. 1994: A Mesozoic time scale. Journal of Geophysical Research 99, 24 051-24 074.

Gravesen, P., Rolle, F. \& Surlyk, F. 1982: Lithostratigraphy and sedimentary evolution of the Triassic, Jurassic and Lower Cretaceous of Bornholm, Denmark. Danmarks Geologiske Undersøgelse Serie B 7, 51 pp.

Gry, H. 1969: Megaspores from the Jurassic of the island of Bornholm, Denmark. Meddelelser fra Dansk Geologisk Forening 19, 69-89.

Guy-Ohlson, D. 1981: Rhaeto-Liassic palynostratigraphy of the Valhall Bore No. 1, Scania. Geologiska Föreningens i Stockholm Förhandlingar 103, 233-248.

Hallam, A. 1984: Continental humid and arid zones during the Jurassic and Cretaceous. Palaeogeography, Palaeoclimatology, Palaeoecology 47, 195-223.

Hallam, A. 1985: A review of Mesozoic climates. Journal of the 
Geological Society (London) 142, 433-445.

Hallam, A. 1988: A reevaluation of Jurassic eustasy in the light of new data and the revised Exxon curve. In: Wilgus, C.K. et al. (eds): Sea-level changes - an integrated approach. Society of Economic Paleontologists and Mineralogists Special Publication 42, 261-273.

Hallam, A. 1992: Phanerozoic sea-level changes. Perspectives in paleobiology and earth history series, 266 pp. New York: Columbia University Press.

Hallam, A. 1997: Estimates of the amount and rate of sea-level change across the Rhaetian-Hettangian and PliensbachianToarcian boundaries (latest Triassic to early Jurassic). Journal of the Geological Society (London) 154, 773-779.

Hallam, A. \& Sellwood, B.W. 1976: Middle Mesozoic sedimentation in relation to tectonics in the British area. Journal of Geology 84, 302-321.

Hamberg, L. 1994: Anatomy of clastic coastal sequences in the Rhaetian Gassum Formation, Stenlille, Denmark, 90 pp. Unpublished Ph.D. thesis, University of Copenhagen, Denmark.

Hamberg, L. \& Nielsen, L.H. 2000: Shingled, sharp-based shoreface sandstones: depositional response to stepwise forced regression in a shallow basin, Upper Triassic Gassum Formation, Denmark. In: Hunt, D. \& Gawthorpe, R.L. (eds): Sedimentary responses to forced regressions. Geological Society Special Publication (London) 172, 69-89.

Hamberg, L., Nielsen, L.H. \& Koppelhus, E.B. 1992: Tidal influence in clastic coastal sequences of the Upper Triassic - Lower Jurassic intracratonic Danish Basin, Denmark. In: Flemming, B.W. (ed.): Tidal Clastics '92, Abstract Volume, 34-35.

Haq, B.U., Hardenbol, J. \& Vail, P.R. 1988: Mesozoic and Cenozoic chronostratigraphy and cycles of sea-level change. In: Wilgus, C.K. et al. (eds): Sea-level changes - an integrated approach. Society of Economic Paleontologists and Mineralogists Special Publication 42, 71-108.

Harms, J.C., Southard, J.B. \& Walker, R.G. 1982: Structures and sequences in clastic rocks. Society of Economic Paleontologists and Mineralogists, Lecture Notes for Short Courses 9, 249 pp.

Helland-Hansen, W. \& Gjelberg, J.G. 1994: Conceptual basis and variability in sequence stratigraphy: a different perspective. Sedimentary Geology 92, 31-52.

Hesselbo, S.P. \& Jenkyns, H.C. 1998: British Lower Jurassic sequence stratigraphy. In: de Graciansky, P.-C. et al. (eds): Mesozoic and Cenozoic sequence stratigraphy of European basins. SEPM (Society for Sedimentary Geology) Special Publication 60, 561-581.

Hunt, D. \& Tucker, M.E. 1992: Stranded parasequences and the forced regressive wedge systems tract: deposition during baselevel fall. Sedimentary Geology 81, 1-9.

Hunt, D. \& Tucker, M.E. 1995: Stranded parasequences and the forced regressive wedge systems tract: deposition during baselevel fall - reply. Sedimentary Geology 95, 147-160.

Hunter, R.E., Clifton, H.E. \& Phillips, R.L. 1979: Depositional processes, sedimentary structures, and predicted vertical sequences in barred near shore systems, southern Oregon coast. Journal of Sedimentary Petrology 49, 111-126.

Japsen, P. \& Langtofte, C. 1991: Geological map of Denmark, 1:400 000 'Top Trias' and the Jurassic - Lower Cretaceous. Danmarks Geologiske Undersøgelse Kortserie 30.
Klingspor, I. 1976: Radiometric age-determinations of basalts, dolerites and related syenite in Skåne, southern Sweden. Geologiska Föreningens i Stockholm Förhandlingar 98 , 195-216.

Koch, J.-O. 1983: Sedimentology of Middle and Upper Jurassic sandstone reservoirs of Denmark. Geologie en Mijnbouw 62 115-129.

Kolla, V., Posamentier, H.W. \& Eichenseer, H. 1995: Stranded parasequences and the forced regressive wedge systems tract: deposition during base-level fall - discussion. Sedimentary Geology 95, 139-145.

Koppelhus, E.B. \& Batten, D.J. 1996: Application of a palynomorph zonation to a series of short borehole sections, Lower to Middle Jurassic, Øresund, Denmark. In: Jansonius, J. \& McGregor, D.C. (eds): Palynology: principles and applications. American Association of Stratigraphic Palynologists Foundation 2, 779-793.

Koppelhus, E.B. \& Nielsen, L.H. 1994: Palynostratigraphy and palaeoenvironments of the Lower to Middle Jurassic Baga Formation of Bornholm, Denmark. Palynology 18, 139-194.

Larsen, G. 1966: Rhaetic - Jurassic - Lower Cretaceous sediments in the Danish Embayment. (A heavy-mineral study). Danmarks Geologiske Undersøgelse II. Række 91, 127 pp.

Larsen, O. 1971: K/Ar age determinations from the Precambrian of Denmark. Danmarks Geologiske Undersøgelse II. Række 97, $37 \mathrm{pp}$.

Larsen, O. 1972: Kalium/argon datering af prøver fra danske dybdeboringer. Dansk Geologisk Forening Årsskrift for 1971 , 91-94.

Larsen, O.H. \& Friis, H. 1991: Petrography, diagenesis and porewater evolution of a shallow marine sandstone (Hasle Formation, Lower Jurassic, Bornholm, Denmark). Sedimentary Geology 72, 269-284.

Leckie, D.A. \& Walker, R.G. 1982: Storm- and tide-dominated shorelines in Cretaceous Moosebar - Lower Gates interval - outcrop equivalents of deep basin gas trap in western Canada. American Association of Petroleum Geologists Bulletin 66, 138-157.

Liboriussen, J., Ashton, P. \& Tygesen, T. 1987: The tectonic evolution of the Fennoscandian Border Zone in Denmark. In: Ziegler, P.A. (ed.): Compressional intra-plate deformations in the Alpine Foreland. Tectonophysics 137, 21-29.

Little-Gadow, S. \& Reineck, H.-E. 1974: Diskontinuierliche Sedimentation von Sand und Schlick in Wattensedimenten. Senckenbergiana Maritima 6, 149-159.

Lund, J.J. 1977: Rhaetic to Lower Liassic palynology of the onshore south-eastern North Sea Basin. Danmarks Geologiske Undersøgelse II. Række 109, 129 pp.

Miall, A.D. 1977: A review of the braided-river depositional environment. Earth-Science Reviews 13, 1-62.

Miall, A.D. 1994: Paleoscene 16. Sequence stratigraphy and chronostratigraphy: problems of definition and precision in correlation, and their implications for global eustasy. Geoscience Canada 21(1), 1-26.

Michelsen, O. 1973: On Liassic holothurian and ostracod assemblages from the Danish Embayment. Danmarks Geologiske Undersøgelse Årbog 1972, 49-68.

Michelsen, O. 1975: Lower Jurassic biostratigraphy and ostracods of the Danish Embayment. Danmarks Geologiske Undersøgelse 
II. Række 104, 287 pp.

Michelsen, O. 1978: Stratigraphy and distribution of Jurassic deposits of the Norwegian-Danish Basin. Danmarks Geologiske Undersøgelse Serie B 2, 28 pp.

Michelsen, O. 1989a: Revision of the Jurassic lithostratigraphy of the Danish Subbasin. Danmarks Geologiske Undersøgelse Serie A 24, 21 pp.

Michelsen, O. 1989b: Log-sequence analysis and environmental aspects of the Lower Jurassic Fjerritslev Formation in the Danish Subbasin. Danmarks Geologiske Undersøgelse Serie A 25, 23 pp.

Michelsen, O. \& Andersen, C. 1981: Überblick über die regionale Geologie und Tektonik Dänemarks. Zeitschrift für Angewandte Geologie 27(5), 171-176.

Michelsen, O. \& Nielsen, L.H. 1991: Well records on the Phanerozoic stratigraphy in the Fennoscandian Border Zone, Denmark. Hans-1, Sæby-1, and Terne-1 wells. Danmarks Geologiske Undersøgelse Serie A 29, 37 pp.

Michelsen, O. \& Nielsen, L.H. 1993: Structural development of the Fennoscandian Border Zone, offshore Denmark. Marine and Petroleum Geology 10, 124-134.

Michelsen, O., Nielsen, L.H., Johannessen, P.N., Andsbjerg, J. \& Surlyk, F. 2003: Jurassic lithostratigraphy and stratigraphic development onshore and offshore Denmark. In: Ineson, J.R. \& Surlyk, F. (eds): The Jurassic of Denmark and Greenland. Geological Survey of Denmark and Greenland Bulletin 1, 147-216 (this volume).

Mitchum, R.M. \& Van Wagoner, J. 1991: High-frequency sequences and their stacking patterns: sequence stratigraphic evidence of high-frequency eustatic cycles. Sedimentary Geology 70, 131-160.

Mogensen, T.E. 1994: Palaeozoic structural development along the Tornquist Zone, Kattegat area, Denmark. In: Cloetingh, S. et al. (eds): Dynamics of extensional basin formation and inversion. Tectonophysics 240, 191-214.

Mogensen, T.E. 1996: Triassic and Jurassic structural development along the Tornquist Zone, Kattegat, Denmark. Tectonophysics 252, 197-220.

Nielsen, L.H. 1993: Øvre Trias - Mellem Jura aflejringerne i Det Danske Bassin. Dansk Geologisk Forenings 100 års jubilæumssymposium - Geologi på tværs af det Danske Rige. Copenhagen, 19-20 November, 1993. Abstracts, 35-38.

Nielsen, L.H. 1995: Genetic stratigraphy of Upper Triassic - Middle Jurassic deposits of the Danish Basin and Fennoscandian Border Zone 2, 3, 162 pp. Unpublished Ph.D. thesis, University of Copenhagen, Denmark.

Nielsen, L.H. \& Japsen, P. 1991: Deep wells in Denmark 1935-1990. Danmarks Geologiske Unders øgelse Serie A 31, 177 pp.

Nielsen, L.H. \& Koppelhus, E.B. 1991: Reworked Carboniferous palynomorphs from the Lower Jurassic on Bornholm and their palaeogeographic significance. Bulletin of the Geological Society Denmark 38, 253-266.

Nielsen, L.H., Johannessen, P.N. \& Surlyk, F. 1988: A Late Pleistocene coarse-grained spit-platform sequence in northern Jylland, Denmark. Sedimentology 35, 915-938.

Nielsen, L.H., Larsen, F. \& Frandsen, N. 1989: Upper Triassic Lower Jurassic tidal deposits of the Gassum Formation on Sjælland, Denmark. Danmarks Geologiske Undersøgelse Serie
A 23, $30 \mathrm{pp}$.

Nielsen, O.B., Seidenkrantz, M.-S., Abrahamsen, N., Schmidt, B.J., Koppelhus, E.B., Ravn-Sørensen, H., Korsbech, U. \& Nielsen, K.G. 2003: The Lower-Middle Jurassic of the Anholt borehole: implications for the geological evolution of the eastern margin of the Danish Basin. In: Ineson, J.R. \& Surlyk, F. (eds): The Jurassic of Denmark and Greenland. Geological Survey of Denmark and Greenland Bulletin 1, 585-609 (this volume).

Norling, E. 1972: Jurassic stratigraphy and foraminifera of western Scania, southern Sweden. Sveriges Geologiska Undersökning Serie Ca 47, 120 pp.

Norling, E. \& Bergström, J. 1987: Mesozoic and Cenozoic tectonic evolution of Scania, southern Sweden. In: Ziegler, P.A. (ed.): Compressional intra-plate deformations in the Alpine Foreland. Tectonophysics 137, 7-19.

Norling, E., Ahlberg, A., Erlström, M. \& Sivhed, U. 1993: Guide to the Upper Triassic and Jurassic geology of Sweden. Sveriges Geologiska Undersökning Ca 82, 71 pp.

Nørvang, A. 1948: Gassum-1 (depth 4970-5637 ft). In: Gassum-1 completion report. Unpublished report, Danish American Prospecting Company, Viborg, Denmark. Compiled (1993) by the Geological Survey of Denmark; Geological Survey of Denmark and Greenland archive file number 4518. Non-paginated.

Nørvang, A. 1957: The foraminifera of the Lias Series in Jutland, Denmark. Meddelelser fra Dansk Geologisk Forening 13, 275-414.

Nummedal, D., Riley, G.W. \& Templet, P.L. 1993: High-resolution sequence architecture: a chronostratigraphic model based on equilibrium profile studies. In: Posamentier, H.W. et al. (eds): Sequence stratigraphy and facies associations. International Association of Sedimentologists Special Publication 18, 55-68.

Park, S.M. 1987: The ostracod zones and subzones of the Lower Jurassic in the southern North Sea Basin. Journal of the Paleontological Society of Korea 1, 44-70.

Parrish, J.T., Ziegler, A.M. \& Scotese, C.R. 1982: Rainfall patterns and the distribution of coals and evaporites in the Mesozoic and Cenozoic. Palaeogeography, Palaeoclimatology, Palaeoecology 40, 67-101.

Partington, M.A., Copestake, P., Mitchener, B.C. \& Underhill, J.R. 1993: Biostratigraphic calibration of genetic stratigraphic sequences in the Jurassic - lowermost Cretaceous (Hettangian to Ryazanian) of the North Sea and adjacent areas. In: Parker, J.R. (ed.): Petroleum geology of Northwest Europe: proceedings of the 4th conference, 371-386. London: Geological Society.

Pedersen, G.K. 1983: En sedimentologisk undersøgelse af den nedre jurassiske Fjerritslev Formation i Det Danske Subbassin, 163 pp. Unpublished Ph.D. thesis, Københavns Universitet, Danmark.

Pedersen, G.K. 1985: Thin, fine-grained storm layers in a muddy shelf sequence: an example from the Lower Jurassic in the Stenlille 1 well. Journal of the Geological Society (London) 142, 357-374

Pedersen, G.K. 1986: Changes in the bivalve assemblage of an early Jurassic mudstone sequence (the Fjerritslev Formation in the Gassum 1 well, Denmark). Palaeogeography, Palaeoclimatology, Palaeoecology 53, 139-168. 
Pedersen, K.R. \& Lund, J.J. 1980: Palynology of the plant-bearing Rhaetian to Hettangian Kap Stewart Formation, Scoresby Sund, East Greenland. Review of Palaeobotany and Palynology 31, 1-69.

Pegrum, R.M. 1984: The extension of the Tornquist Zone in the Norwegian North Sea. Norsk Geologisk Tidsskrift 64, 39-68.

Penland, S., Boyd, R. \& Suter, J.R. 1988: Transgressive depositional systems of the Mississippi delta plain: a model for barrier shoreline and shelf sand development. Journal of Sedimentary Petrology 58, 932-949.

Petersen, H.I. \& Nielsen, L.H. 1995: Controls on peat accumulation and depositional environments of a coal-bearing coastal plain succession of a pull-apart basin; a petrographic, geochemical and sedimentological study, Lower Jurassic, Denmark. International Journal of Coal Geology 27, 99-129.

Petersen, H.I., Nielsen, L.H., Koppelhus, E.B. \& Sørensen, H.S. 2003: Early and Middle Jurassic mires of Bornholm and the Fennoscandian Border Zone: a comparison of depositional environments and vegetation. In: Ineson, J.R. \& Surlyk, F. (eds): The Jurassic of Denmark and Greenland. Geological Survey of Denmark and Greenland Bulletin 1, 631-656 (this volume).

Pieńkowski, G. 1991: Eustatically-controlled sedimentation in the Hettangian-Sinemurian (Early Jurassic) of Poland and Sweden. Sedimentology 38, 503-518.

Plint, A.G. 1988: Sharp-based shoreface sequences and 'offshore bars' in the Cardium Formation of Alberta: their relationship to relative changes in sea level. In: Wilgus, C.K. et al. (eds): Sea-level changes - an integrated approach. Society of Economic Paleontologists and Mineralogists Special Publication 42, 357-370.

Plint, A.G. \& Nummedal, D. 2000: The falling stage systems tract: recognition and importance in sequence stratigraphic analysis. In: Hunt, D. \& Gawthorpe, R.L. (eds): Sedimentary responses to forced regressions. Geological Society Special Publication (London) 172, 1-17.

Posamentier, H.W. \& Morris, W.R. 2000: Aspects of the stratal architecture of forced regressive deposits. In: Hunt, D. \& Gawthorpe, R.L. (eds): Sedimentary responses to forced regressions. Geological Society Special Publication (London) 172, 19-46.

Posamentier, H.W., Jervey, M.T. \& Vail, P.R. 1988: Eustatic controls on clastic deposition I - conceptual framework. In: Wilgus, C.K. et al. (eds): Sea-level changes - an integrated approach. Society of Economic Paleontologists and Mineralogists Special Publication 42, 110-124.

Posamentier, H.W., Allen, G.P., James, D.P. \& Tesson, M. 1992: Forced regressions in a sequence stratigraphic framework: concepts, examples, and exploration significance. American Association of Petroleum Geologists Bulletin 76, 1687-1709.

Poulsen, C. 1969: The Lower Cambrian from Slagelse no. 1, Western Sealand. Danmarks Geologiske Undersøgelse II. Række 93, 27 pp.

Poulsen, C. 1974: Further contributions to the knowledge of the Palaeozoic of Slagelse no. 1, Western Sealand. Danmarks Geologiske Undersøgelse II. Række 101, 72 pp.

Poulsen, N.E. 1992a: Dinoflagellate cysts from marine Jurassic deposits in the Danish Subbasin and from Poland, $184 \mathrm{pp}$. Unpublished Ph.D. thesis, University of Copenhagen, Denmark.

Poulsen, N.E. 1992b: Jurassic dinoflagellate cyst biostratigraphy of the Danish Subbasin in relation to sequences in England and Poland; a preliminary review. Review of Palaeobotany and Palynology 75, 33-52.

Poulsen, N.E. 1996: Dinoflagellate cysts from marine Jurassic deposits of Denmark and Poland. American Association of Stratigraphic Palynologists Contribution Series 31, 227 pp.

Poulsen, N.E. \& Riding, J.B. 2003: The Jurassic dinoflagellate cyst zonation of Subboreal Northwest Europe. In: Ineson, J.R. \& Surlyk, F. (eds): The Jurassic of Denmark and Greenland. Geological Survey of Denmark and Greenland Bulletin 1, 115-144 (this volume)

Printzlau, I. \& Larsen, O. 1972: K-Ar age determinations on alkaline olivine basalts from Skåne, south Sweden. Geologiska Föreningens i Stockholm Förhandlingar 94, 259-269.

Ravn-Sørensen, H. 1989: En palynologisk undersøgelse af Jura i Haldager-1 og Børglum-1 boringerne, 146 pp. Unpublished cand. scient. thesis, Aarhus Universitet, Danmark.

Ro, H.E., Larsson, F.R., Kinck, J.J. \& Husebye, E.S. 1990: The Oslo Rift - its evolution on the basis of geological and geophysical observations. In: Neumann, E.-R. (ed.): Rift zones in the continental crust of Europe - geophysical, geological and geochemical evidence: Oslo-Horn Graben. Tectonophysics 178, 11-28.

Rolle, F., Koch, J.-O., Frandsen, N. \& Surlyk, F. 1979: Jurassic environments in the Fenno-Scandian Border Zone. Symposium on 'Sédimentation jurassique W. européen'. Association Sedimentologie Francais Publication Spéciale 1, 15-31.

Schmidt, B. 1985: Clay mineral investigation of the Rhaetic Jurassic - Lower Cretaceous sediments of the Børglum-1 and Uglev-1 wells, Denmark. Bulletin of the Geological Society of Denmark 34, 97-110.

Scotese, C.R. 1994: Early and Middle Jurassic maps. In: Klein, G.H. (ed.): Pangea: Paleoclimate, tectonics, and sedimentation during accretion, zenith, and breakup of a super-continent. Geological Society of America Special Paper 288.

Seidenkrantz, M.-S., Koppelhus, E.B. \& Ravn-Sørensen, H. 1993: Biostratigraphy and palaeoenvironmental analysis of a Lower to Middle Jurassic succession on Anholt, Denmark. Journal of Micropalaeontology 12, 201-218.

Sivhed, U. 1980: Lower Jurassic ostracodes and stratigraphy of western Skåne, southern Sweden. Sveriges Geologiska Undersökning Serie Ca 50, 84 pp.

Sivhed, U. 1984: Litho- and biostratigraphy of the Upper Triassic - Middle Jurassic in Scania, southern Sweden. Sveriges Geologiska Undersökning Serie C 806, 31 pp.

Smith, D.G. 1983: Anastomosed fluvial deposits: modern examples from western Canada. In: Collinson, J.D. \& Lewin, J. (eds): Modern and ancient fluvial systems. International Association of Sedimentologists Special Publication 6, 155-168.

Smith, D.G. 1988: Modern point bar deposits analogous to the Athabasca Oil Sands, Alberta, Canada. In: de Boer, P.L., van Gelder, A. \& Nio, S.D. (eds): Tide-influenced sedimentary environments and facies, 417-432. Dordrecht: Reidel Publishing Company.

Sorgenfrei, T. \& Buch, A. 1964: Deep tests in Denmark, 1935-1959. Danmarks Geologiske Undersøgelse III. Række 36, 146 pp.

Stemmerik, L., Frykman, P., Christensen, O.W. \& Stentoft, N. 1987: The Zechstein carbonates of southern Jylland, Denmark. In: Brooks, J. \& Glennie, K.W. (eds): Petroleum Geology of North West Europe, 365-374. London: Graham \& Trotman. 
Stratlab a.s. 1988: Well 5708/18-1. Biostratigraphy, kerogen analysis, 56 pp. Unpublished report, Stratlab a.s.

Surlyk, F. 1977: Mesozoic faulting in East Greenland. In: Frost, R.T.C. \& Dikkers, A.J. (eds): Fault tectonics in N.W. Europe. Geologie en Mijnbouw 56, 311-327.

Surlyk, F. 1978: Jurassic basin evolution of East Greenland. Nature 274, 130-133.

Surlyk, F. 1990: A Jurassic sea-level curve for East Greenland. Palaeogeography, Palaeoclimatology, Palaeoecology 78, 71-85.

Surlyk, F. 1991: Sequence stratigraphy of the Jurassic - lowermost Cretaceous of East Greenland. American Association of Petroleum Geologists Bulletin 75, 1468-1488.

Surlyk, F., Arndorff, L., Hamann, N.-E., Hamberg, L., Johannessen, P.N., Koppelhus, E.B., Nielsen, L.H., Noe-Nygaard, N., Pedersen, G.K. \& Petersen, H.I. 1995: High-resolution sequence stratigraphy of a Hettangian-Sinemurian paralic succession, Bornholm, Denmark. Sedimentology 42, 323-354.

Terwindt, J.H.J. 1981: Origin and sequences of sedimentary structures in inshore mesotidal deposits of the North Sea. In: Nio, S.-D., Shüttenhelm, R.T.E. \& van Weering, T.C.E. (eds): Holocene marine sedimentation in the North Sea Basin. International Association of Sedimentologists Special Publication 5, 4-26.

Thomas, R.G., Smith, D.G., Wood, J.M., Visser, J., Calverley Range, E.A. \& Koster, E.H. 1987: Inclined heterolithic stratification terminology, description, interpretation and significance. Sedimentary Geology 53, 123-179.

Thompson, W.O. 1937: Original structures of beaches, bars and dunes. Geological Society of America Bulletin 48, 723-752.

Thomsen, E. 1984: A coal petrographical investigation of the well Års-1. DGU confidential report 1, 19 pp. Copenhagen: Geological Survey of Denmark.

Thomsen, E., Damtoft, K. \& Andersen, C. 1987: Hydrocarbon plays in Denmark outside the Central Trough. In: Brooks, J. \& Glennie, K.W. (eds): Petroleum geology of North West Europe, 375-388. London: Graham \& Trotman.

Tralau, H. 1973: En palynologisk åldersbestämning av vulkanisk aktivitet i Skåne. Fauna och Flora 68, 121-125.

Troedsson, G. 1948: Om fynd av rätiska fossil i Skåne. Geologiska Föreningens i Stockholm Förhandlingar 70, 528-550.

Troedsson, G. 1951: On the Höganäs Series of Sweden (RhaetoLias). Lunds Universitet Årsskrift Ny Följd 2 47(1), 269 pp.

Underhill, J.R. \& Partington, M.A. 1993: Jurassic thermal doming and deflation in the North Sea: implications of the sequence stratigraphic evidence. In: Parker, J.R. (ed.): Petroleum geology of Northwest Europe: proceedings of the 4th conference, 337-345. London: Geological Society.

Underhill, J.R. \& Partington, M.A. 1994: Use of genetic sequence stratigraphy in defining and determining a regional tectonic control on the 'mid-Cimmerian Unconformity' - implications for North Sea basin development and the global sea-level chart. In: Weimer, P. \& Posamentier, H.W. (eds): Siliciclastic sequence stratigraphy: recent developments and applications. American Association of Petroleum Geologists Memoir 58, 449-484. van Straaten, L.M.J.U. \& Kuenen, P.H. 1957: Accumulation of finegrained sediments in the Dutch Wadden Sea. Geologie en Mijnbouw 19, 329-354.

Van Wagoner, C. 1995: Sequence stratigraphy and marine to nonmarine facies architecture of foreland basin strata, Book Cliffs, Utah, U.S.A. In: Van Wagoner, J.C. \& Bertram, G.T. (eds): Sequence stratigraphy of foreland basin deposits. American Association of Petroleum Geologists Memoir 64, 137-223.

Van Wagoner, J.C., Mitchum, R.M., Campion, K.M. \& Rahmanian, V.D. 1990: Siliciclastic sequence stratigraphy in well logs, cores, and outcrops: concepts for high-resolution correlation of time and facies. American Association of Petroleum Geologists Methods in Exploration Series 7, 55 pp.

Vejbæk, O.V. 1985: Seismic stratigraphy and tectonics of sedimentary basins around Bornholm, southern Baltic. Danmarks Geologiske Undersøgelse Serie A 8, 30 pp.

Vejbæk, O.V. 1989: Effects of asthenospheric heat flow in basin modelling exemplified with the Danish Basin. Earth and Planetary Science Letters 95, 97-114.

Vejbæk, O.V. 1990: The Horn Graben, and its relationship to the Oslo Graben and the Danish Basin. In: Neumann, E.-R. (ed.): Rift zones in the continental crust of Europe - geophysical, geological and geochemical evidence: Oslo-Horn Graben. Tectonophysics 178, 29-49.

Vejbæk, O.V. 1997: Dybe strukturer i danske sedimentære bassiner. Geologisk Tidsskrift 4, 1-31.

Vejbæk, O.V. \& Britze, P. (eds) 1994: Geological map of Denmark 1:750 000. Top pre-Zechstein (two-way traveltime and depth). Danmarks Geologiske Undersøgelse Kortserie 45, 8 pp., 6 maps.

Visser, M.J. 1980: Neap-spring cycles reflected in Holocene subtidal large-scale bedform deposits: a preliminary note. Geology 8, 543-546.

Walker, R.G. \& Plint, A.G. 1992: Wave- and storm-dominated shallow marine systems. In: Walker, R.G. \& James, N.P. (eds): Facies models: response to sea-level change, 219-238. Ontario: Geological Assosiation of Canada.

Whiteman, A.J., Rees, G., Naylor, D. \& Pegrum, R.M. 1975: North Sea troughs and plate tectonics. Norges Geologiske Undersøkelse 316, 137-161.

Woollam, R. \& Riding, J.B. 1983: Dinoflagellate cyst zonation of the English Jurassic. Institute of Geological Sciences Report 83/2, 44 pp.

Yükler, M.A., Cornford, C. \& Welte, J. 1978: One-dimensional model to simulate geologic, hydrodynamic and thermodynamic development of a sedimentary basin. Geologische Rundschau 67, 960-979.

Ziegler, P.A. 1982: Geological atlas of western and central Europe, 130 pp. The Hague: Elsevier for Shell Internationale Petroleum Maatschappij.

Ziegler, P.A. 1990: Tectonic and palaeogeographic development of the North Sea rift system. In: Blundell, D.J. \& Gibbs, A.D. (eds): Tectonic evolution of the North Sea rifts, 1-36. Oxford: Clarendon Press. 


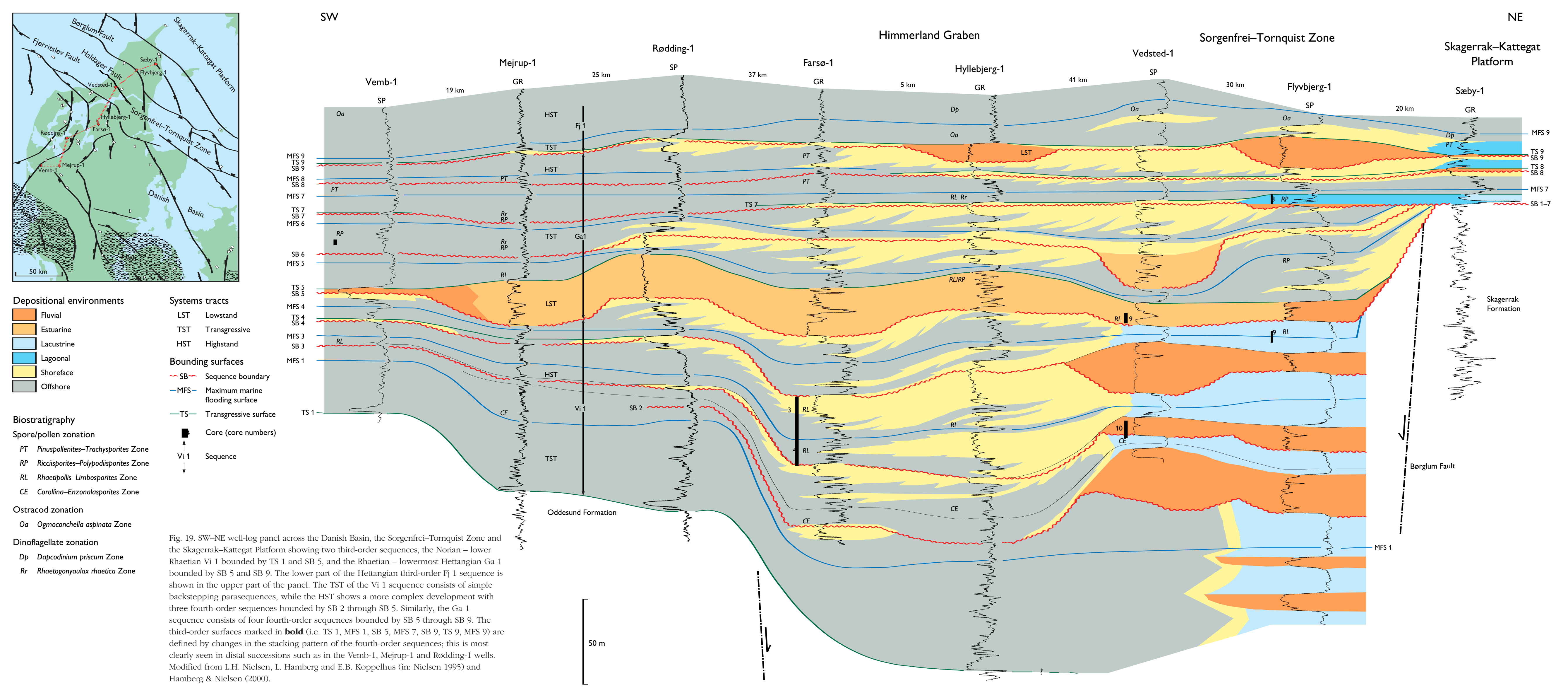




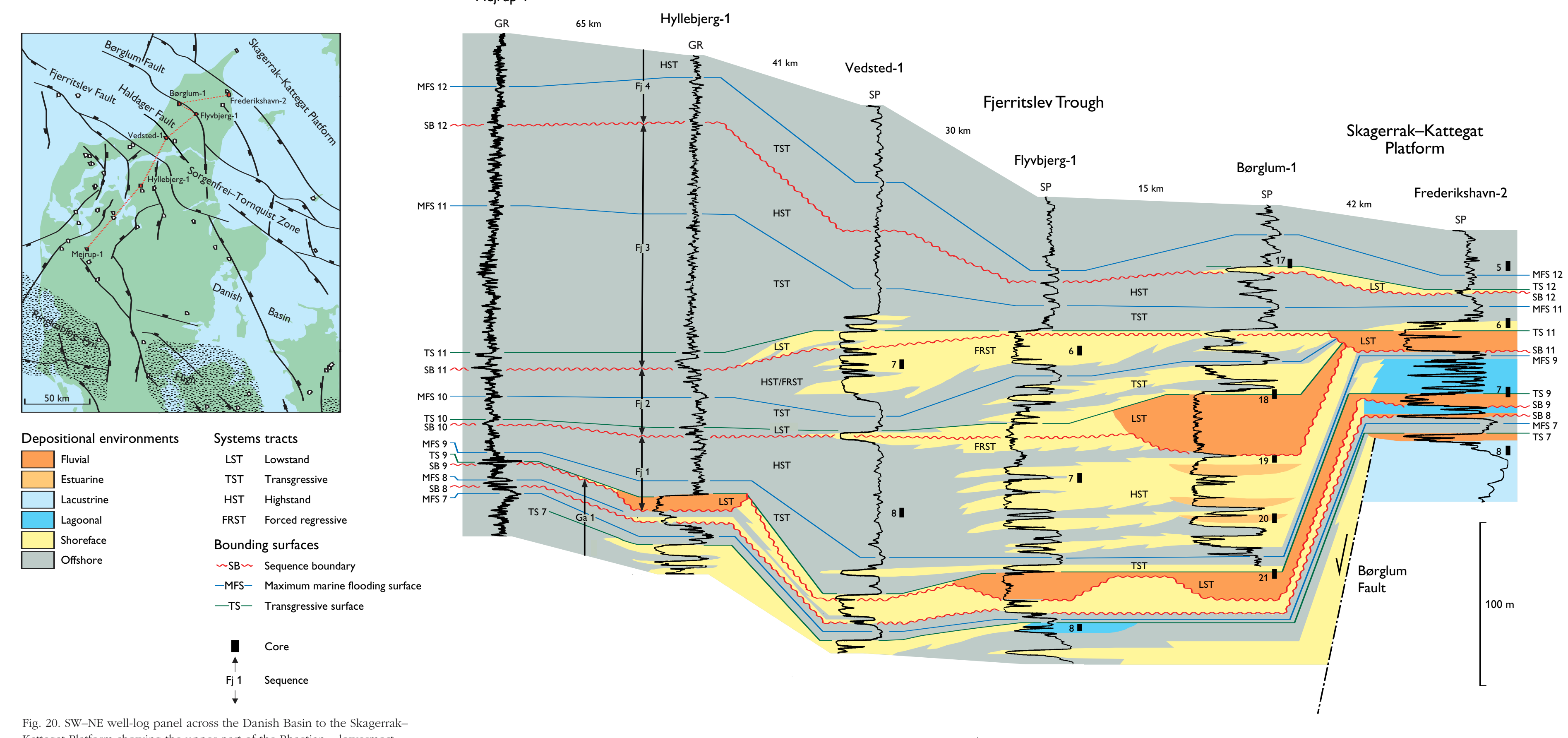

Fig. 20. SW-NE well-og panel across she Danish Basin to the Skagerarak-
Kattegat Platorom showing the upper part of the Rhe haetian - lowermost

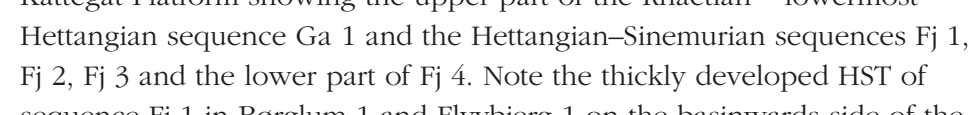

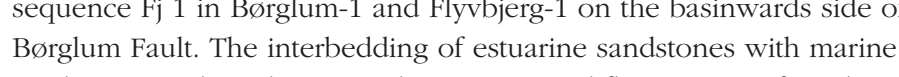
mudstones and sandstones indiciates repeated fluctuations of sea level
during the formation of hh HST and sugests the presence of several
fourth-order sequences at this level. 
Rødding-1

Skive-1

Kvols-1

Hyllebjerg-1

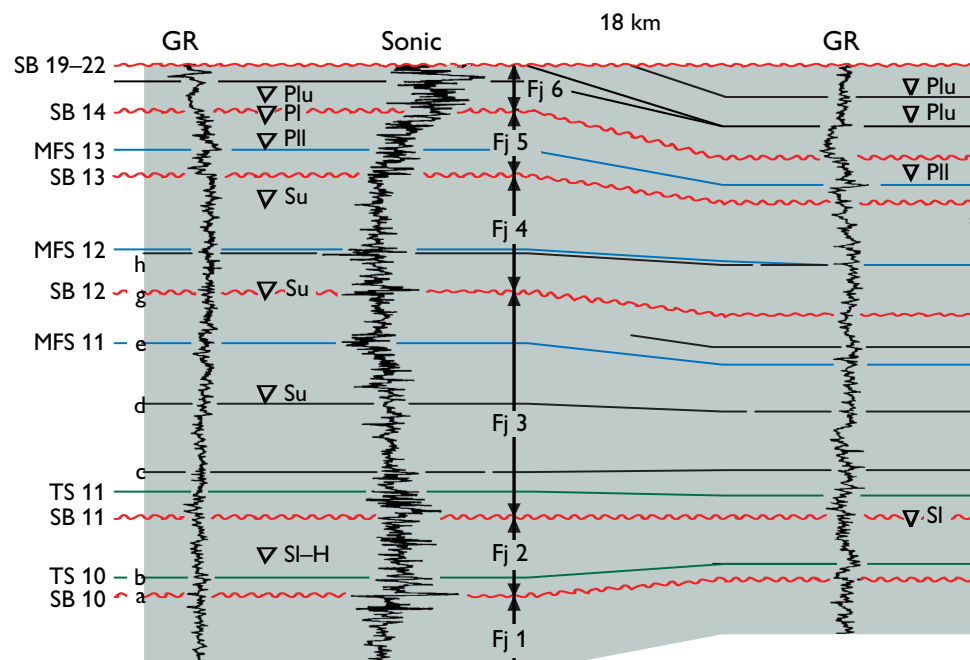

$12 \mathrm{~km}$

$19 \mathrm{~km}$

Sonic $\quad 32 \mathrm{~km}$

$32 \mathrm{~km}$ GR
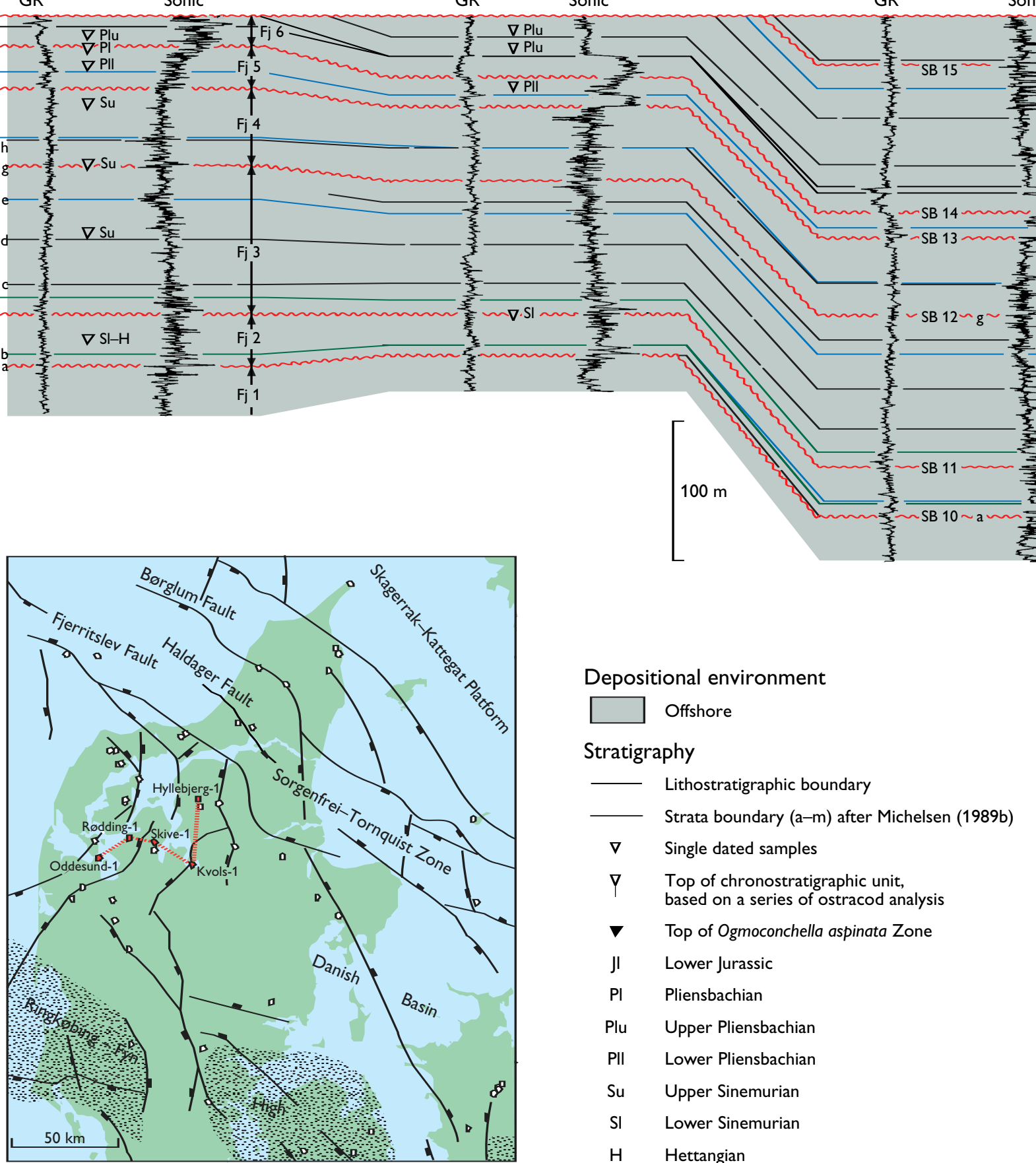

Depositional environment

\section{$\square$ offshore}

Stratigraphy

- Lithostratigraphic boundary

....... Strata boundary (a-m) after Michelsen (1989b)

S.... Strata boundary $(\mathrm{a}-\mathrm{m})$
$\nabla$

Top of chronostratigraphic unit,
based on a series of ostracod analysis

- Top of Ogmoconchella aspinata Zone

JI Lower Jurassic

PI Pliensbachian

Plu Upper Pliensbachian

PII Lower Pliensbachian

Su Ull Lower Pliensbachian

$\begin{array}{ll}\text { Su } & \text { Upper Sinemurian } \\ \text { SI } & \text { Lower Sinemurian }\end{array}$

$\mathrm{H}$ Hettangian

Fig. 21. Well-log panel showing the basinal part of the sequences Fj 1 to Fj 8 from Hyllebjerg-1 (Himmerland Graben) Middle Jurassic snat well sections. An increasing anount of erosion is seen towards the south-west below the base (1989b) are defined by subtle changes in lithology, and are interneted as chronostratigraphic matkers that reflect

basinwide changes in the relatively uniform and deep marine environment. 

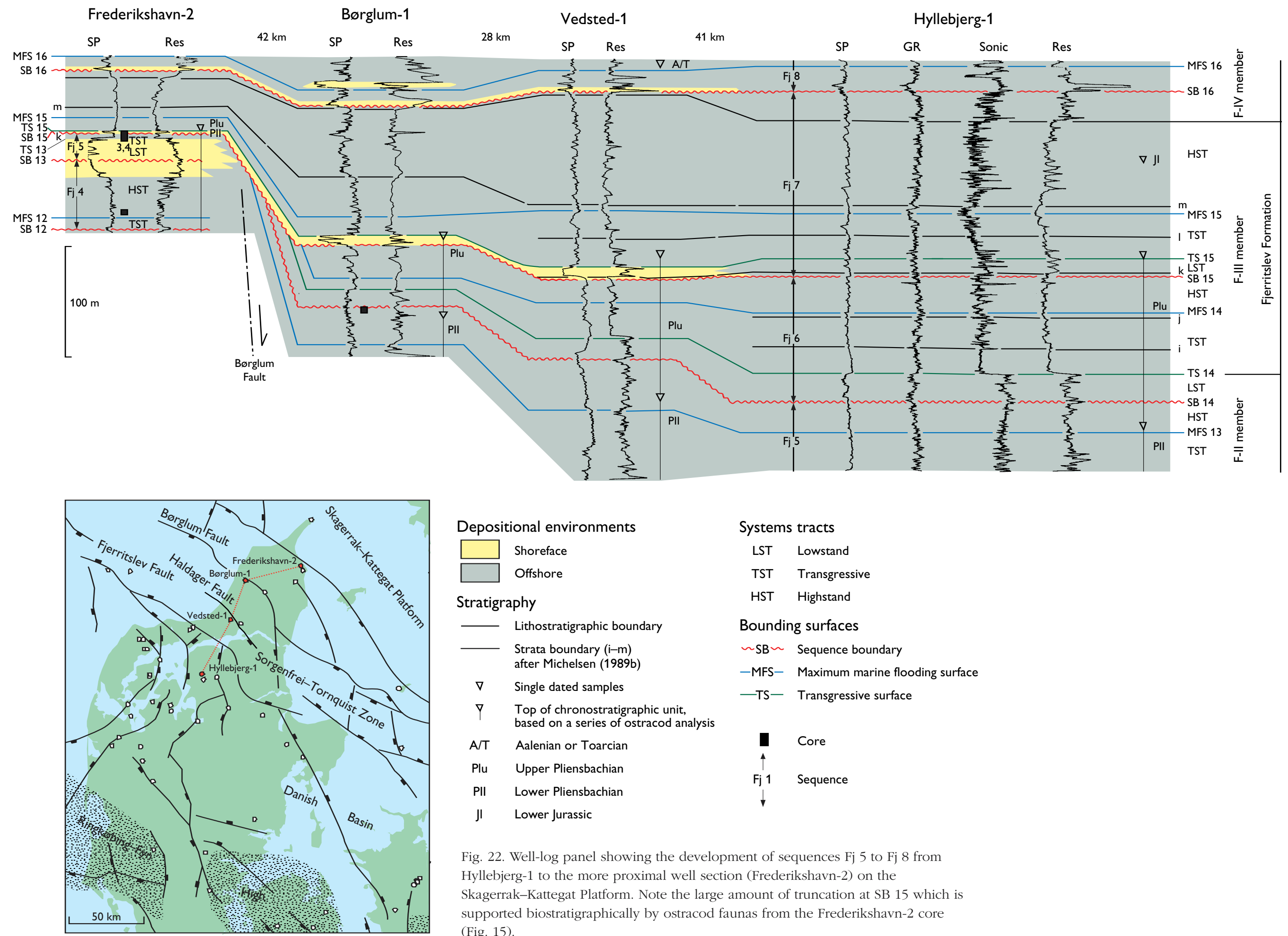

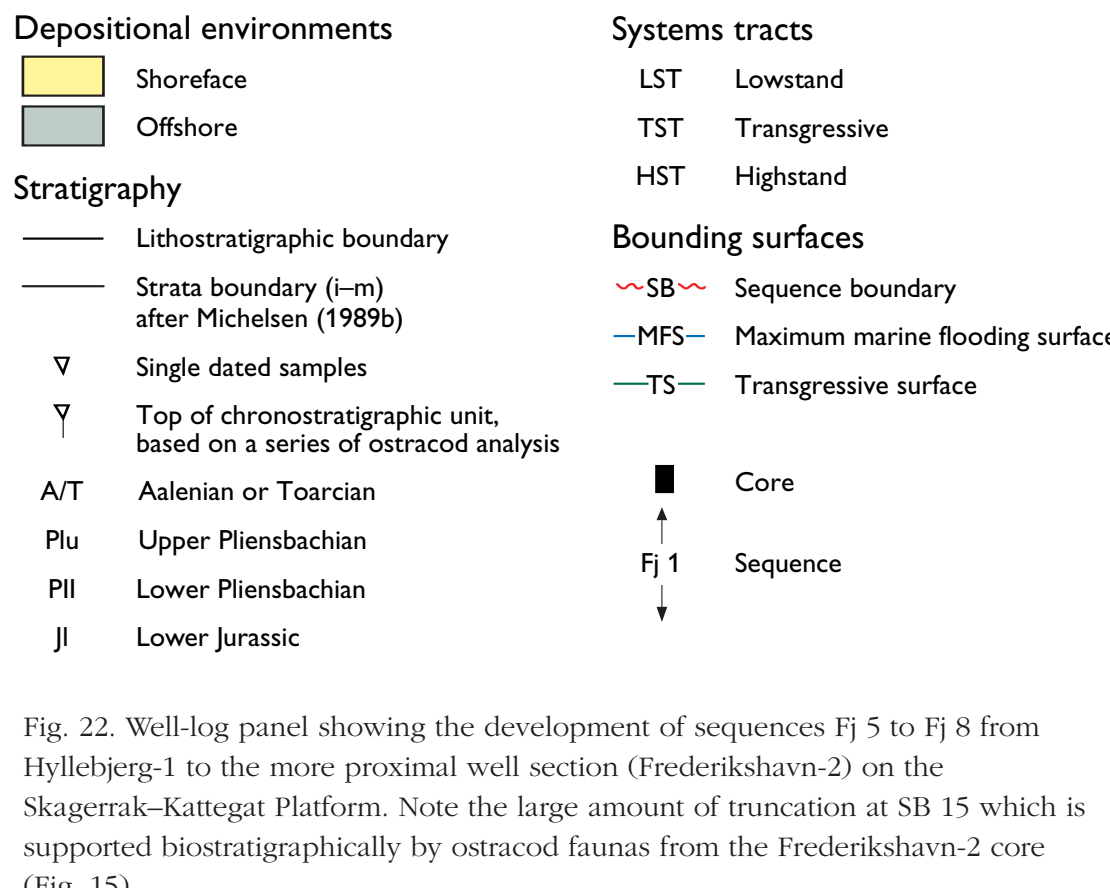




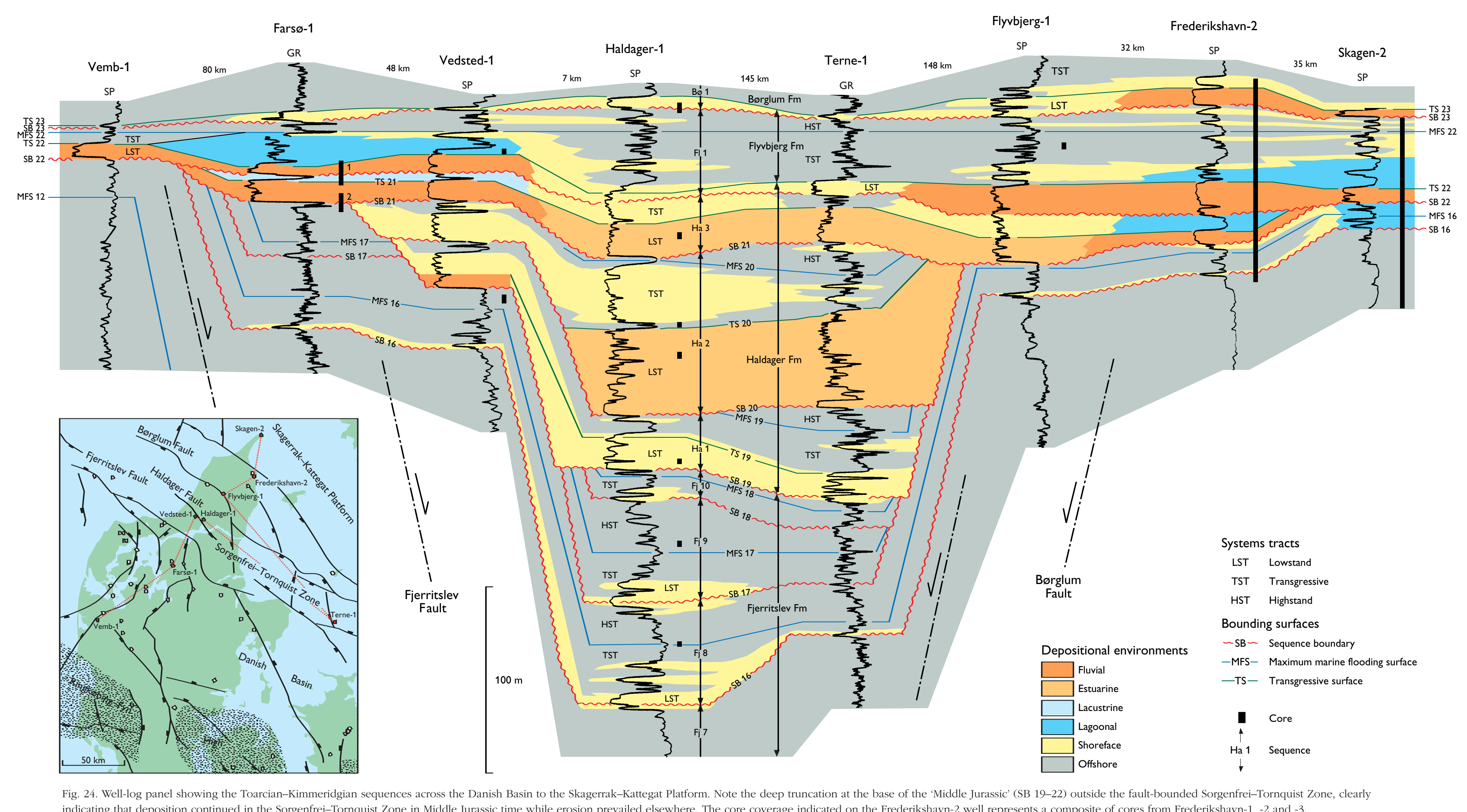




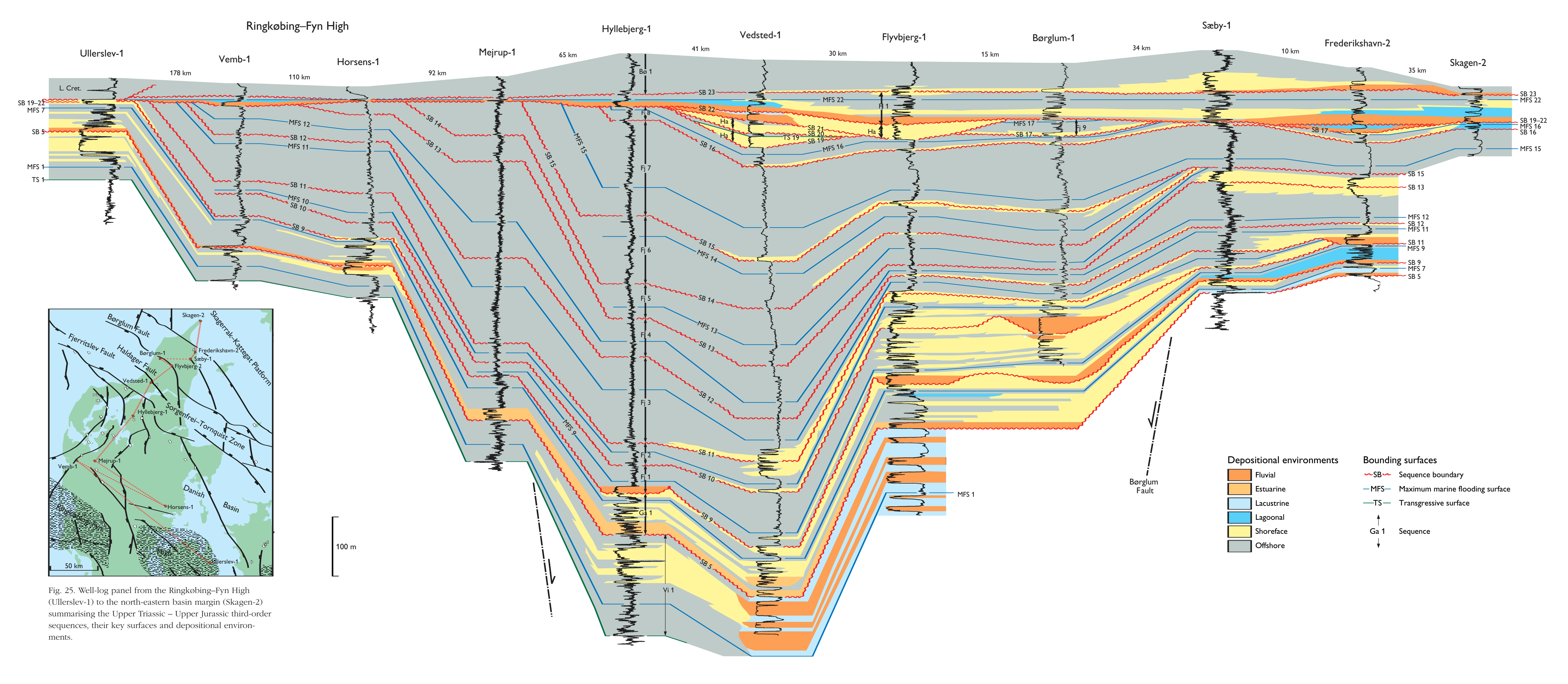

